\title{
The Regulatory Efficiency of the CCMA: A Statistical Analysis of the CCMA's CMS Database
}

\author{
Paul Benjamin \\ Director \\ Cheadle Thompson \& Haysom Inc \\ paul@cthcpt.co.za \\ and \\ Carola Gruen \\ University of the Witwatersrand \\ gruenc@sebs.wits.ac.za
}




\section{Acknowledgement}

This Working Paper is one in a series emanating from the SMME project, within the Employment Promotion Programme, which is aimed at Understanding the Regulatory Environment for Small Business in South Africa. The DPRU are the Programme Managers of this DFID funded project whose goal is to promote an enabling environment for employment creation in South Africa, and to contribute to the Government's goal of reducing unemployment.

Information about our Working Papers and other published titles are available on our website at: http://www.commerce.uct.ac.za/dprul 


\section{Table of Contents}

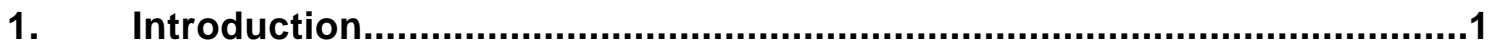

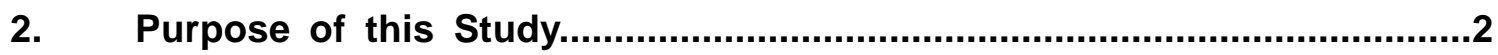

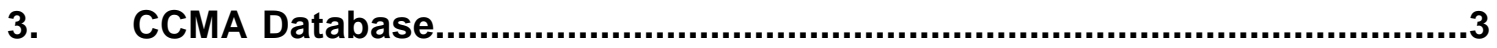

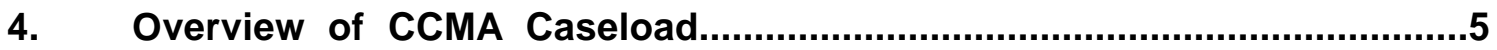

5. Unfair Dismissals and Unfair Labour Practices....................................17

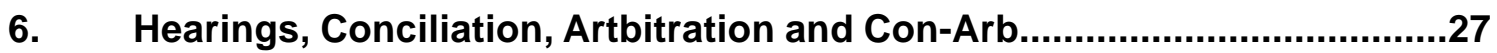

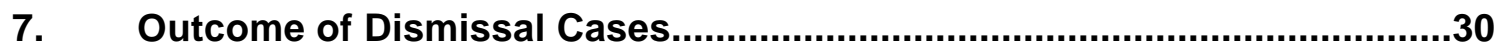

8. Indicators of Administrative Efficiency.................................................38

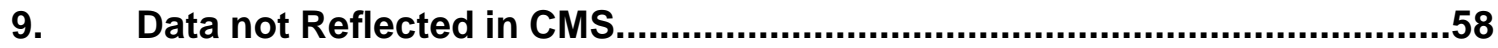

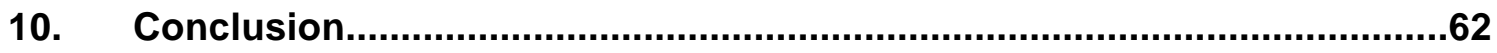

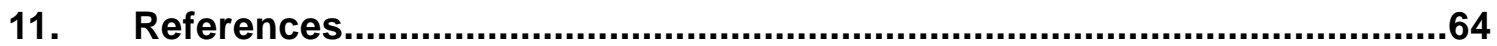

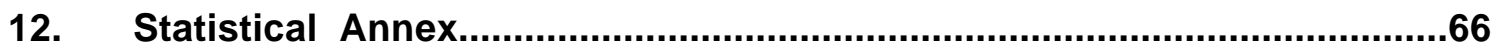




\section{Abstract}

The study involves a statistical analysis of the case management system (CMS) database of the Commission for Conciliation Mediation and Arbitration (CCMA) for the financial years 2001/2, 2003/4 and 2004/5. It focuses on statistical indicators that shed light on the administrative efficiency of the CCMA and the outcome of proceedings at the CCMA as a basis for assessing its regulatory efficiency in respect of resolving unfair dismissals and unfair labour practices.

The study concludes that there are marked differences in patterns of dispute resolution and the outcome of disputes in the CCMA's different provincial regions. These regional variations are significantly greater than those between different economic sectors. A closer scrutiny of these differences contributed to an improved understanding of the successes and failures of the CCMA.

The CMS database on which the study is based is designed for case management purposes and this orientation is reflected in the information contained in the database. Accordingly, key information required for assessing efficiency of the CCMA and to inform policy decisions is not contained in the CMS database and consideration should be given to expanding the database for these purposes. 


\section{Introduction}

The Commission for Conciliation, Mediation and Arbitration (CCMA) was established as a new dispute resolution body in November 1996. Its main objective is to ensure the swift and expeditious resolution of employment disputes. Since its establishment, the number of cases referred to the CCMA has increased substantially (Annual Reports, 1996-2004). The overwhelming majority of cases concern unfair dismissal, followed by unfair labour practice, collective bargaining and severance pay.

The establishment of the CCMA raised a number of expectations. Firstly, it was hoped that disputes could be resolved more effectively and that the national settlement rate would increase therefore reducing the incidence of strikes and lockouts (CCMA, 2005). Secondly, by providing comprehensive guidelines and training it was hoped that both employers and employees would learn about the correct procedures and code of conducts which ultimately should result in a lower caseload for the CCMA.

Since the CCMA took over responsibility, the national settlement rate has been relatively high and stable at more than 70 per cent. Compared to the previous bodies (Conciliation Boards and Industrial Court), the CCMA performs much more effectively in this regard and clearly contributes to sound labour and industrial relations within the South African economy. Strike statistics show a significant decline in levels of industrial action. The report assessing of the first decade of democracy Towards a Ten-Year Review describes the achievement of South Africa's post-apartheid labour market regime in the following terms

"South Africa has made great strides in introducing and amending labour laws that give employers and employees certainty and security in their employment relationship. The huge fall in person-strike-days bears testimony to the success of the policy. The balance between the degree of job security and the kind of labour market flexibility that encourages employers to take on new employees is still being negotiated amongst the economic role-players."(at39.) 


\section{Purpose of this Study}

The purpose of the study is to undertake a statistical analysis of the database of the CCMA to seek to understand patterns of dispute referral, settlement and determination regionally, sectorally and historically. This study is exploratory seeking to ascertain what light can be thrown on the debate surrounding the CCMA and in particular, its impact upon SMMEs, by an analysis of the CCMA's database. The study focuses primarily on unfair dismissal as the major category of disputes referred to the CCMA.

The study compares the figures from the CMS in respect of three completed years: $2001 / 2002,2003 / 4$ and $2004 / 2005$. The choice of these particular financial years is significant in that:

a) significant amendments to the Labour Relations Act altered the operation of the CCMA and introduced a new set of CCMA rules came into effect on 1 August 2002. The financial years chosen therefore offer the possibility of a 'before and after' comparison in respect of the changes introduced by the 2002 Amendments;

b) three other significant changes in the labour law regime which may have impacted on the number of disputes referred to the CCMA also occurred during this period:

(i) the first sectoral determination under the Basic Conditions of Employment Act for domestic workers came into effect on 15 August 2002;

(ii) the first sectoral determination under the Basic Conditions of Employment Act for farmworkers came into effect on 2 December 2002;

(iii) the Unemployment Insurance Act of 2001 came into effect on 1 April 2002. 


\section{CCMA Database}

The CCMA has, from its inception, operated an electronic case management system (CMS). Each dispute referred to the CCMA is recorded and entered into this database.

There are a number of mandatory fields in CMS which must be filled in respect of every case. The Mandatory fields are:
a) Case creation date
b) Issue occurred date
c) District of origin
d) Jurisdiction state
e) Number affected in workplace
f) Sector
g) Industry
h) Locality (e.g Johannesburg)
i) Province/region
j) All party details (name, contact details)
k) Issue
I) Arbitration referral form date
m) Process
n) Outcome
o) Award in favour of
p) Award date 
This information is recorded at the point when the dispute is first referred to the CCMA and updated as the dispute progresses through the CCMA. The major source of information for these reports is the applicant who in the case of dismissal disputes is the employee concerned. The CMS allows for the accurate tracking of the progress of disputes within the CCMA.

The CCMA produces an annual Review of Operations analysing the data contained in the CMS. The Review disaggregates the data on a regional basis allowing for a comparison of the operation of the CCMA's different regional offices.

In addition, the CCMA maintains monthly dispute resolution reports. These reports include certain information not included in the CMS including the number of review applications launched in the Labour Court in respect of CCMA awards.

In respect of the total caseload of the CCMA, the figures retrieved from the CCMA database match the official numbers remarkably well: the difference in 2001/02 is practically negligible and in 2004/05 it amounts to less than 1.5 per cent. 


\section{Overview of CCMA Caseload}

\section{Total Number of Referrals}

Table 1: Total Number of Cases Referred to the CCMA ${ }^{1}$

\begin{tabular}{|c|c|c|c|c|c|c|c|c|c|}
\hline & 1996 & $1997 / 98$ & $1998 / 99$ & $1999 / 00$ & $2000 / 01$ & $2001 / 02$ & $2002 / 03$ & $2003 / 04$ & $2004 / 05$ \\
\hline seload & 2,917 & 6 & 86 , & 56 & 103 & $\begin{array}{r}110,639 \\
{[110,553]}\end{array}$ & $\begin{array}{r}118,254 \\
{[126,330]}\end{array}$ & 127,715 & $\begin{array}{c}128,018 \\
{[126,272]}\end{array}$ \\
\hline
\end{tabular}

Source: CCMA Annual Reports, 1996-2003/04. Official figures for 2004/05 are taken from "Review of Operations, 2004-2005". Numbers given in brackets were retrieved from the CCMA database.

Figure 1: CCMA Caseload, 1996-2004/05

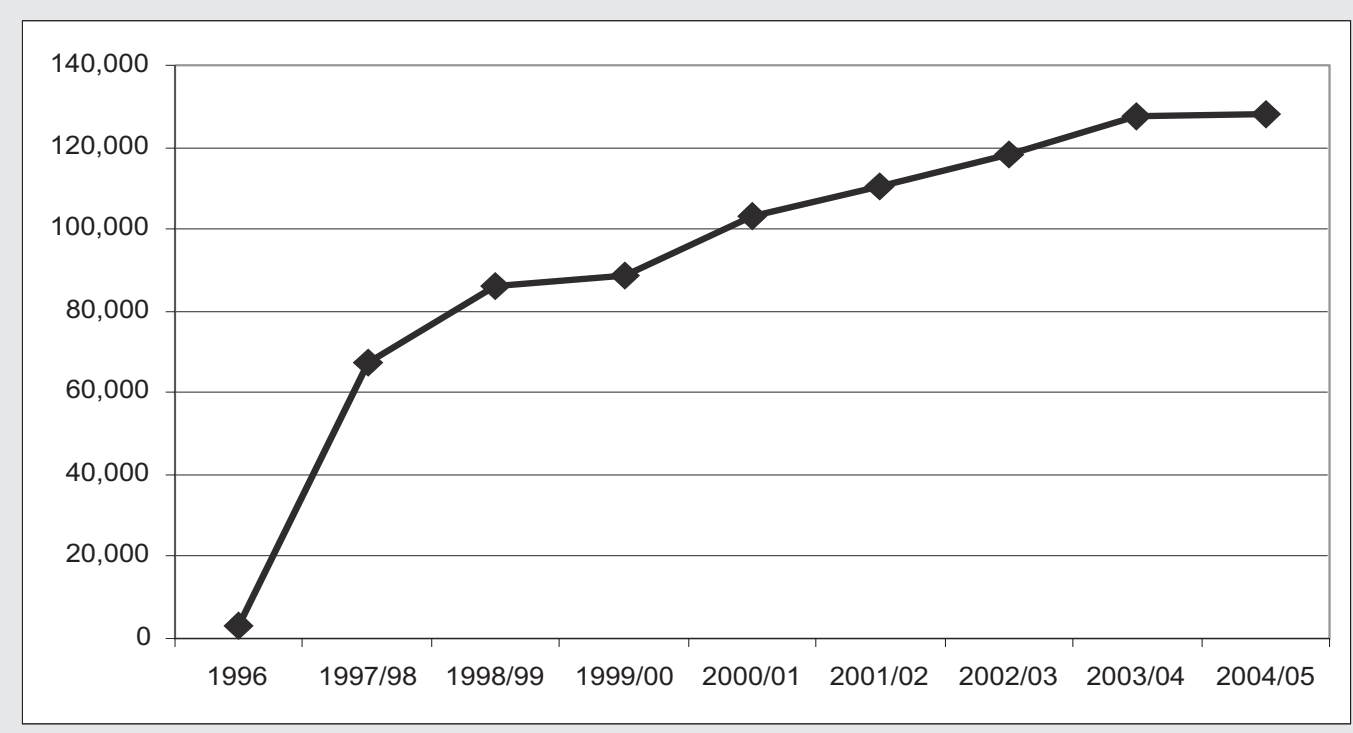

Table 1 and Figure 1 show the total number of disputes that are referred to the CCMA. This reveals that there has been a steady increase in the number of cases referred with the result that the number of disputes referred in 2004-2005 is almost double that referred in the first full financial year of operation 1997/8.

1 For 1996, the relevant time period runs from 11 November until 31 December. For the remaining periods, the financial year figures are given (1 April - 31 March following year). 
Figure 2: Total Referrals by Region

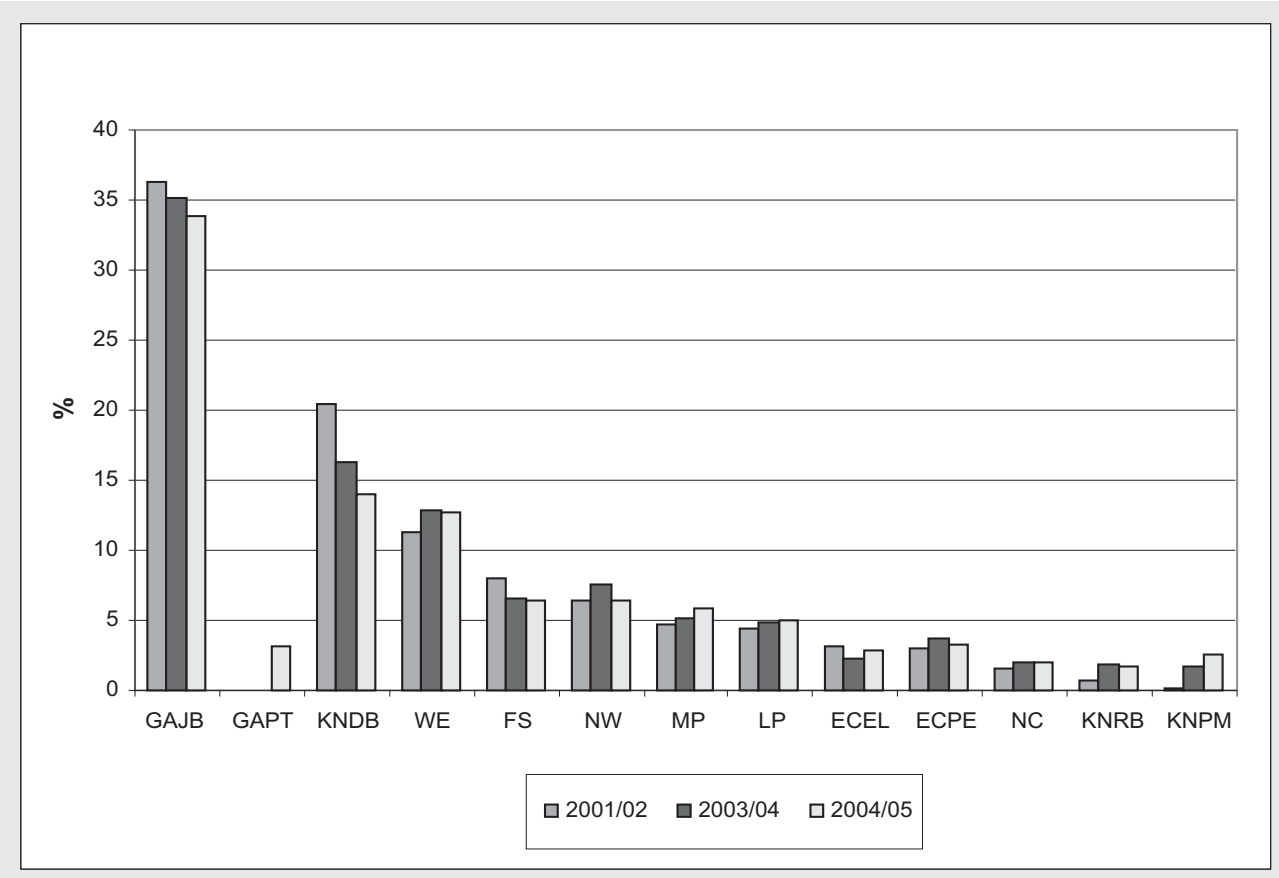

Figure 3: Total Referrals by Main Sector

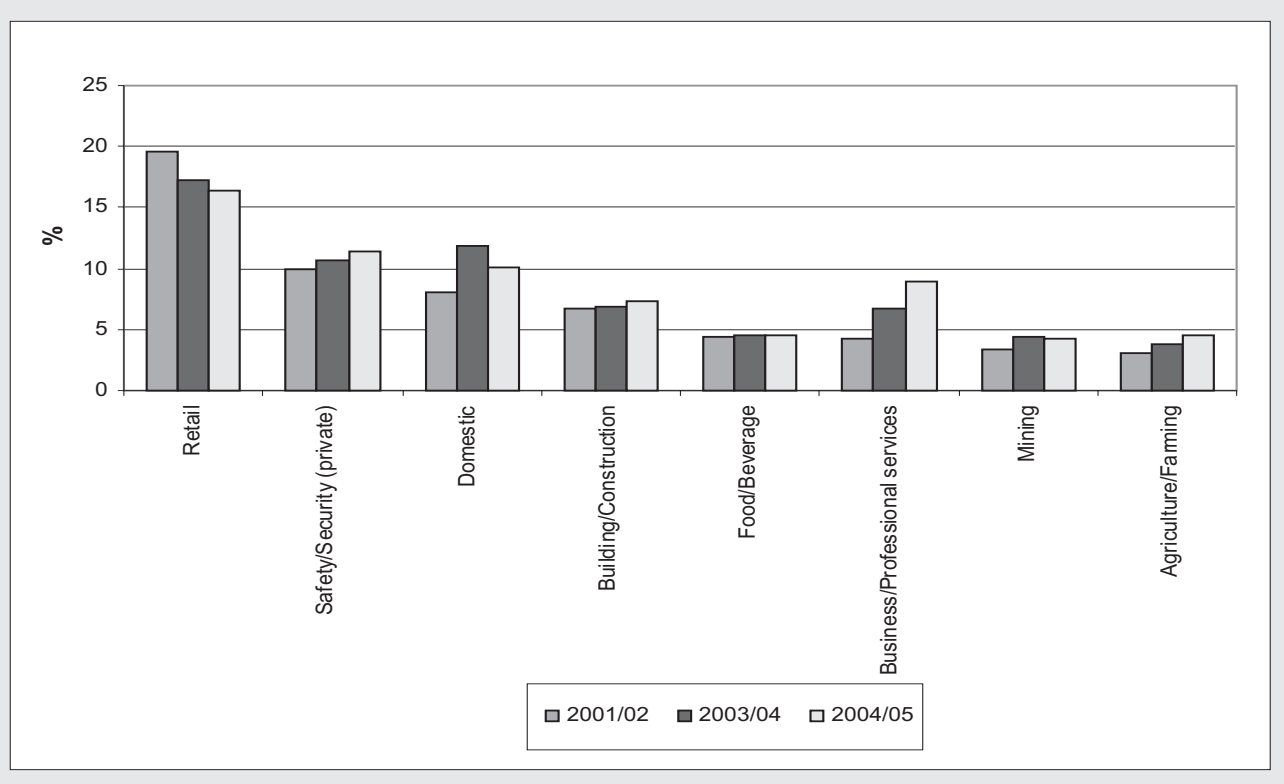




\section{Main Sectors (Total Number of Referrals)}

Table 2: Main sectors (in percentage)

\begin{tabular}{|l|r|r|r|r|r|r|r|r|r|}
\hline & 1996 & $1997 / 98$ & $1998 / 99$ & $1999 / 00$ & $2000 / 01$ & $2001 / 02$ & $2002 / 03$ & $2003 / 04$ & $2004 / 05$ \\
\hline Retail $^{2}$ & 19 & 20 & 20 & 21 & 19 & $20[20]$ & 17 & $17[17]$ & $16[16]$ \\
\hline Private security & 7 & 7 & 8 & 9 & 10 & $10[10]$ & 10 & $11[11]$ & $11[11]$ \\
\hline Food/Beverages & 11 & 6 & 6 & 6 & 5 & $4[4]$ & 5 & $5[5]$ & $5[5]$ \\
\hline $\begin{array}{l}\text { Building } \\
\text { construction }\end{array}$ & 6 & 6 & 6 & 6 & 7 & $7[7]$ & 7 & $7[7]$ & $7[7]$ \\
\hline $\begin{array}{l}\text { Domestic } \\
\text { Agriculture }\end{array}$ & -- & 6 & 6 & 8 & 8 & $8[8]$ & 10 & $12[12]$ & $10[10]$ \\
$\begin{array}{l}\text { Business } \\
\text { services }\end{array}$ & -- & 5 & 4 & 5 & -- & $3[3]$ & 5 & $5[5]$ & $5[5]$ \\
\hline
\end{tabular}

Source: CCMA Annual Reports, 1996-2003/04. Official figures for 2004/05 are taken from "Review of Operations, 2004-2005". Numbers given in brackets were retrieved from the CCMA database.

For all years, the retail sector contributed most to the caseload of the CCMA. Over the years, the share has been declining from a peak in 1999/2000 of 21 per cent to 16 per cent in 2004/05. Other sectors like private security, domestic sector, and business services have gained in significance. Together, these sectors accounted for 30 per cent of the total caseload in 2004/05.

Table 3: Main Sector (\%, Official Classification)

\begin{tabular}{|c|c|c|c|}
\hline & $2001 / 02$ & $2003 / 04$ & $2004 / 05$ \\
\hline A134: Community, social, personal se rvices & 32.1 & 34.8 & 33.7 \\
\hline A131: Trade, catering, accommodation services & 24.8 & 22.0 & 20.9 \\
\hline A121: Manufacturing & 13.3 & 10.9 & 11.0 \\
\hline A132: Transport, storage, communication & 7.4 & 6.3 & 6.3 \\
\hline $\begin{array}{l}\text { A133: Financial intermediation, insurance, real estate, business } \\
\text { services }\end{array}$ & 6.9 & 8.6 & 10.5 \\
\hline A123: Construction & 6.7 & 6.8 & 7.3 \\
\hline A111: Agriculture, forestry, fishing & 4.3 & 5.1 & 5.0 \\
\hline A112: Mining & 3.3 & 4.4 & 4.2 \\
\hline A122: Electricity, gas, water & 1.1 & 1.0 & 0.9 \\
\hline
\end{tabular}

Note: Retail sector is included in A131, private security and domestic in A134, food/beverages in A121, building/ construction in A123, business services in A133.

2 Until 1999, this sector was recorded as "Commercial distributive" in the CCMA database. 
Figure 4: Share of Employment and Referrals by Official Sector Classification, 2001

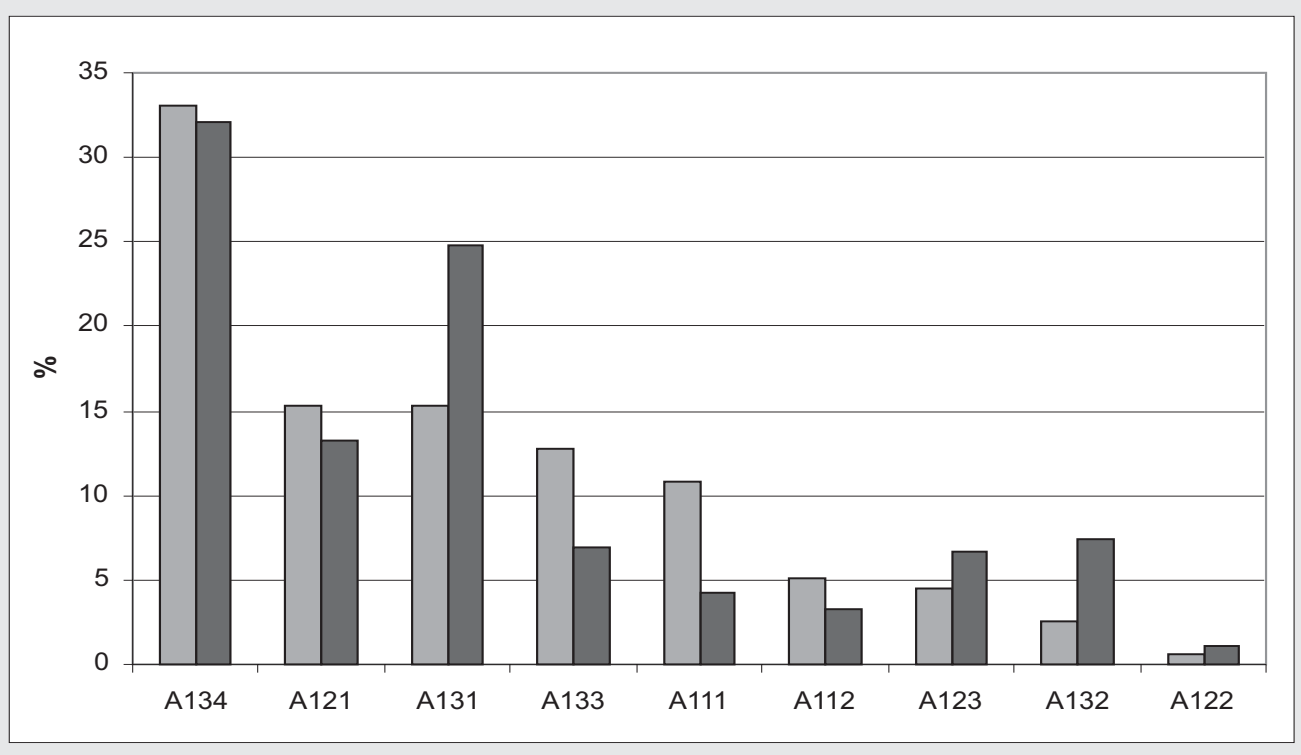

Note: First bar represents percentage of total workers employed in each sector; second bar shows the proportion of referrals accruing from each sector. For a full description of sector classification, see Table 6. Official employment data has been retrieved from the TIPS database.

Figure 5: Share of Employment and Referrals by Official Sector Classification, 2003

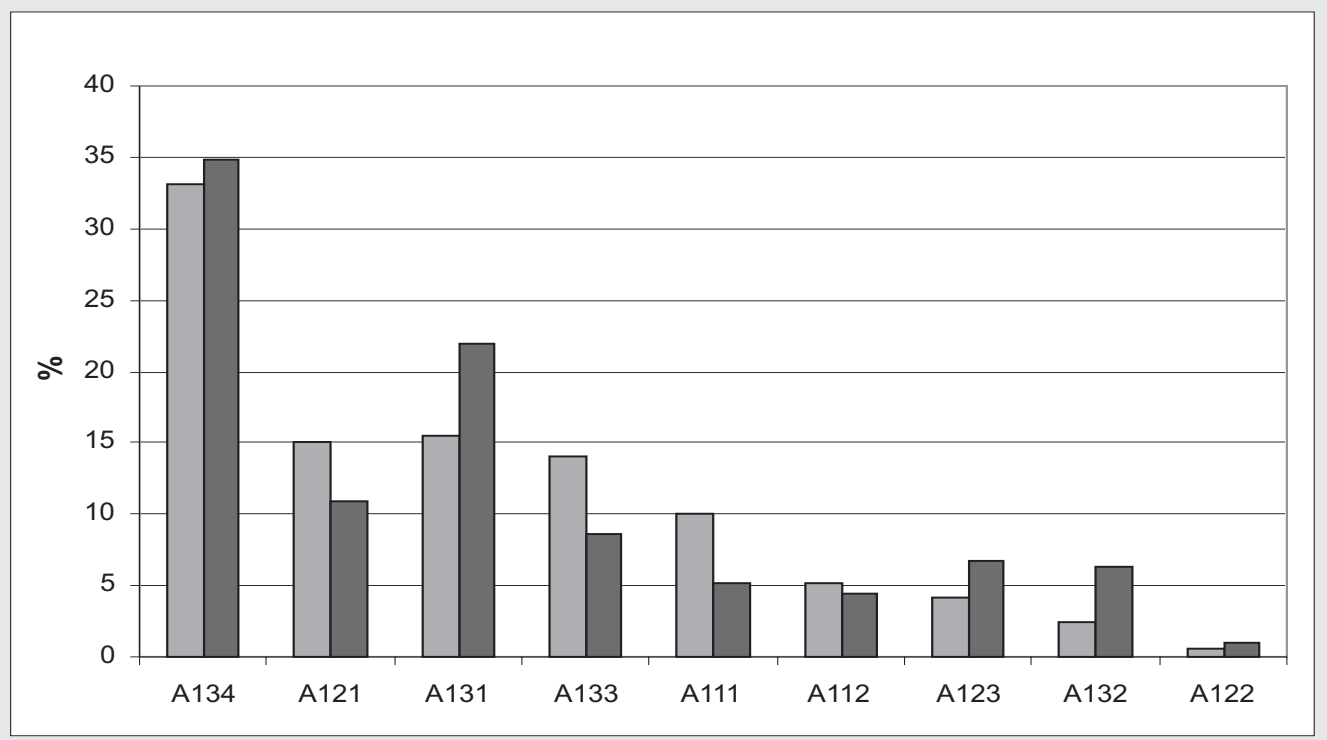

Note: See notes for Figure 4. 
Figure 6: Share of Employment and Referrals by Official Sector Classification, 2004

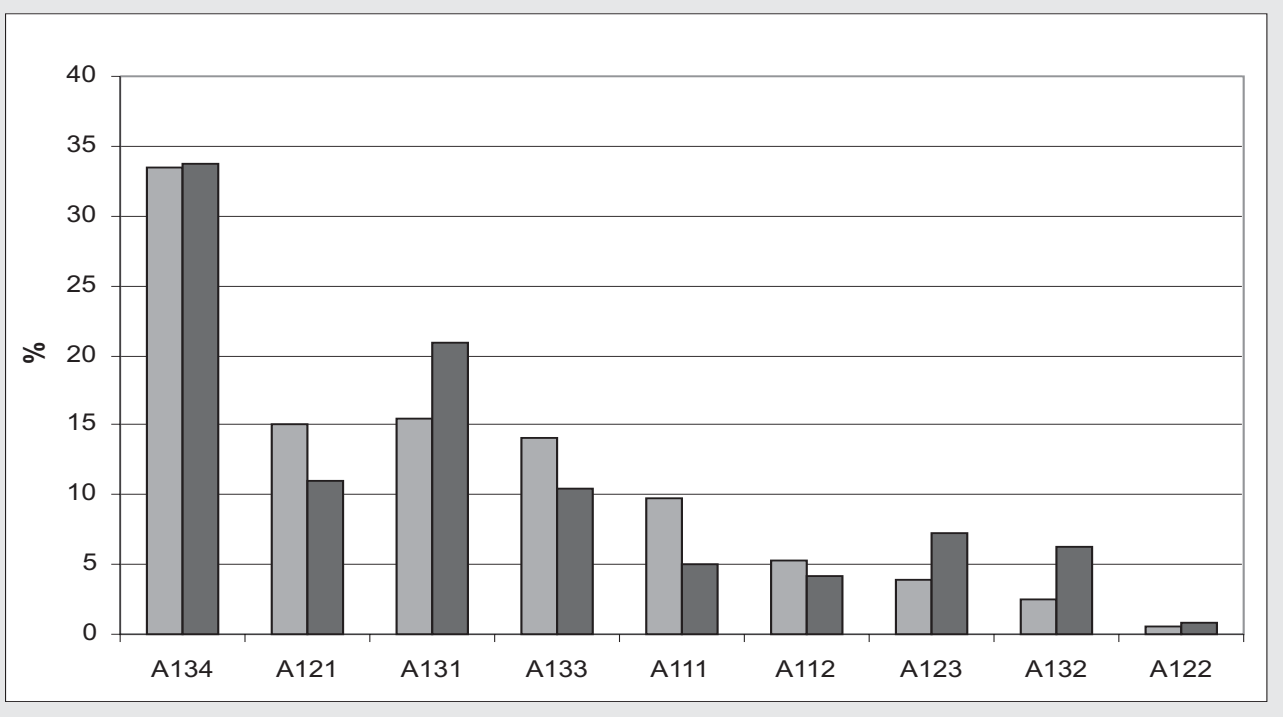

Note: See notes for Figure 4.

\section{Comparison with Official Statistics}

In order to be able to compare CMS figures with official employment statistics, it is necessary to re-classify the sectors given in the CCMA database according to standardised industry codes. Attempts have been made to apply both the three digit industrial code and the (more detailed) four digit industrial code to the CCMA sector classification. According to the former, nine sectors could be identified, as shown in Table 5. However, important categories such as retail and domestic are not mentioned separately. Although the four digit industrial code allows for a more disaggregated view as it would yield 21 different sectors in total, particular sectors that seem to be very important for the CCMA, like domestic, are still concealed. In addition, the CCMA data sometimes does not provide enough information to correctly re-classify the sectors. As the related measurement error might be considerable, we refrain from reporting the four digit industrial breakdown. 
Table 4: Referrals by Main Types of Disputes ${ }^{3}$

\begin{tabular}{|l|rr|rr|rr|}
\hline & \multicolumn{2}{|c|}{$\mathbf{2 0 0 1 / 0 2}$} & \multicolumn{2}{c|}{$\mathbf{2 0 0 3 / 0 4}$} & \multicolumn{2}{|c|}{$\mathbf{2 0 0 4 / 0 5}$} \\
\hline & Frequency & Percent & Frequency & Percent & Frequency & Percent \\
\hline Unfair dismissal & 76,182 & 80.38 & 89,968 & 83.48 & 87,673 & 79.89 \\
Unfair labour practice & 7,750 & 8.18 & 7,441 & 6.90 & 7,860 & 7.16 \\
\hline Mutual interest & 2,099 & 2.21 & 1,176 & 1.09 & 1,498 & 1.36 \\
Severance pay & 2,996 & 3.16 & 2,592 & 2.41 & 2,058 & 1.88 \\
\hline Cumulative & $\mathbf{8 9 , 0 2 7}$ & $\mathbf{9 3 . 9 3}$ & $\mathbf{1 0 1 , 1 7 7}$ & $\mathbf{9 3 . 8 8}$ & $\mathbf{9 9 , 0 8 9}$ & $\mathbf{9 0 . 2 9}$ \\
\hline
\end{tabular}

Table 4 is calculated on the basis of all cases referred to the CCMA. It therefore includes those that are rejected because they should have been referred to a bargaining council as well as those in which the referral is incomplete. A comparison between Table 4 and Table 7 indicates that approximately 20000 unfair dismissal disputes are classified as being 'out of jurisdiction'.

Figure 7: Unfair Dismissal Cases (Total Referrals) by Region

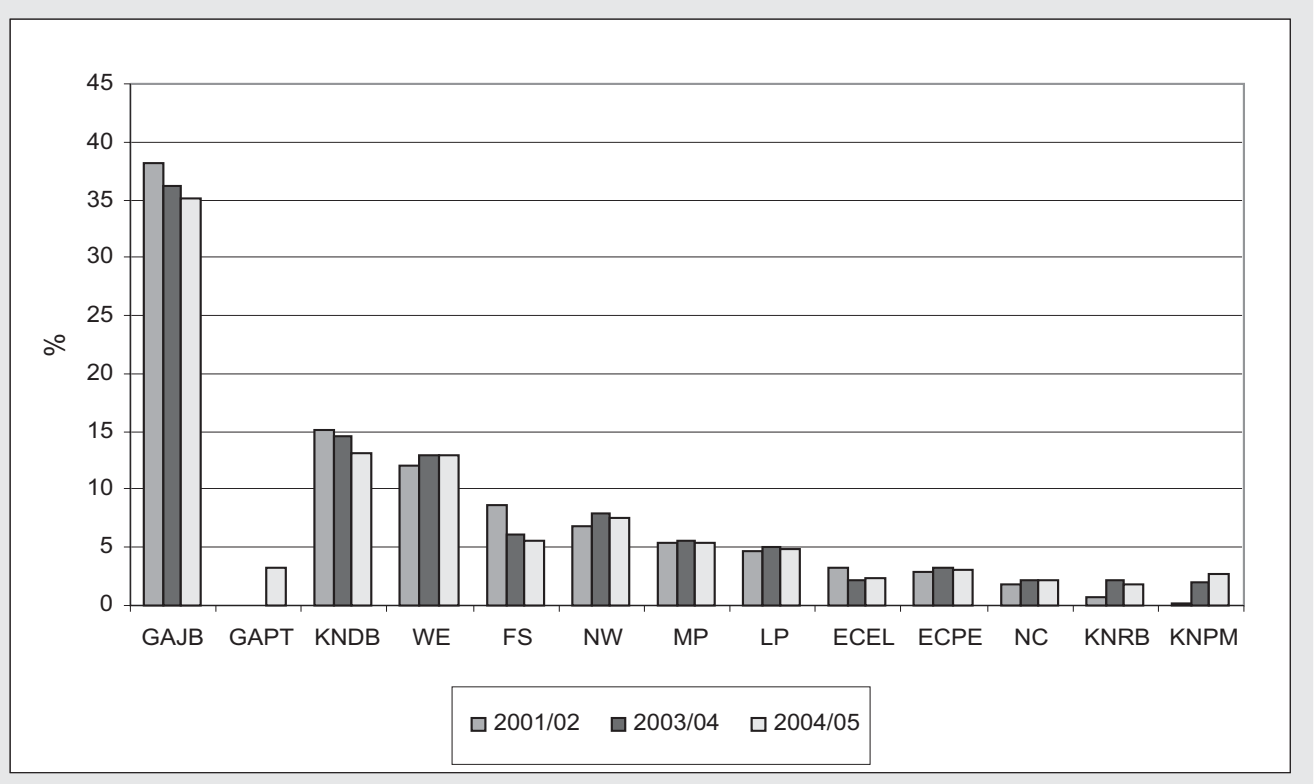

3 The underlying total number for this breakdown is somewhat lower for all years. Not total number of referrals but genuine disputes are considered. This approach which reduces each year's sample by approximately 15 per cent guarantees that our results are comparable to the numbers reported in the Annual Reports and Review of Operations published by the CCMA. Unfair dismissal and unfair labour practice reflect aggregated numbers. See also Tables 8 and 9. 
Figure 8: Unfair Dismissal Cases (Total Referrals) by Main Sector ${ }^{4}$



As illustrated in Figure 8, the number of unfair dismissal cases submitted from domestic workers and employees in the agricultural sector has gone up. Only business and professional services, which belong to the fast growing sectors of the economy, experienced a higher growth rate. The significance of other sectors has declined over time.

4 Compared to Table 2, one sector has been added. The public sector shown here comprises the following CCMA sector classification: Municipality/Local Government, Office of the President, Parliament (national), Post Office, Premier's office, Prisons (public), Public Education, Public Health \& Welfare, Public Safety \& Security, Public Service \& Administration, Public Service (General). 
Comment: Domestic Workers and Agriculture

Figure 9: Unfair Labour Practice (Total Referrals) by Region

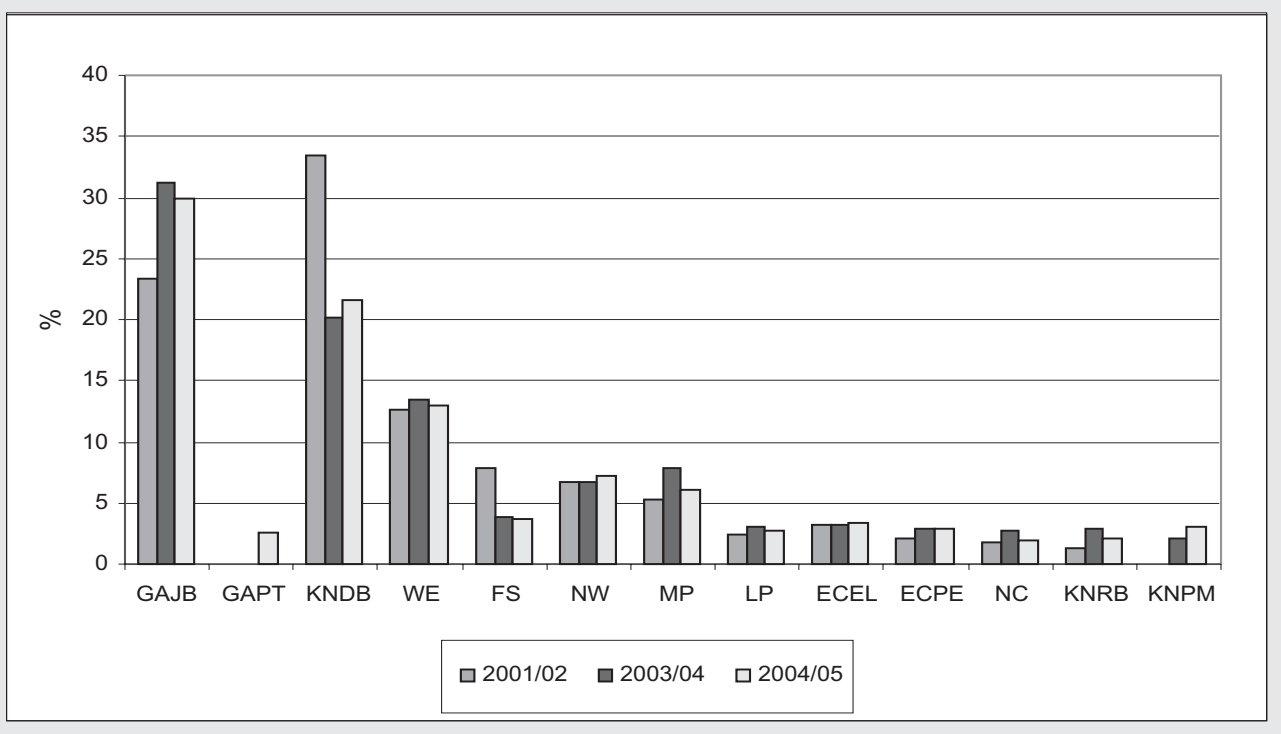

Figure 10: Unfair Labour Practice (Total Referrals) by Main Sector

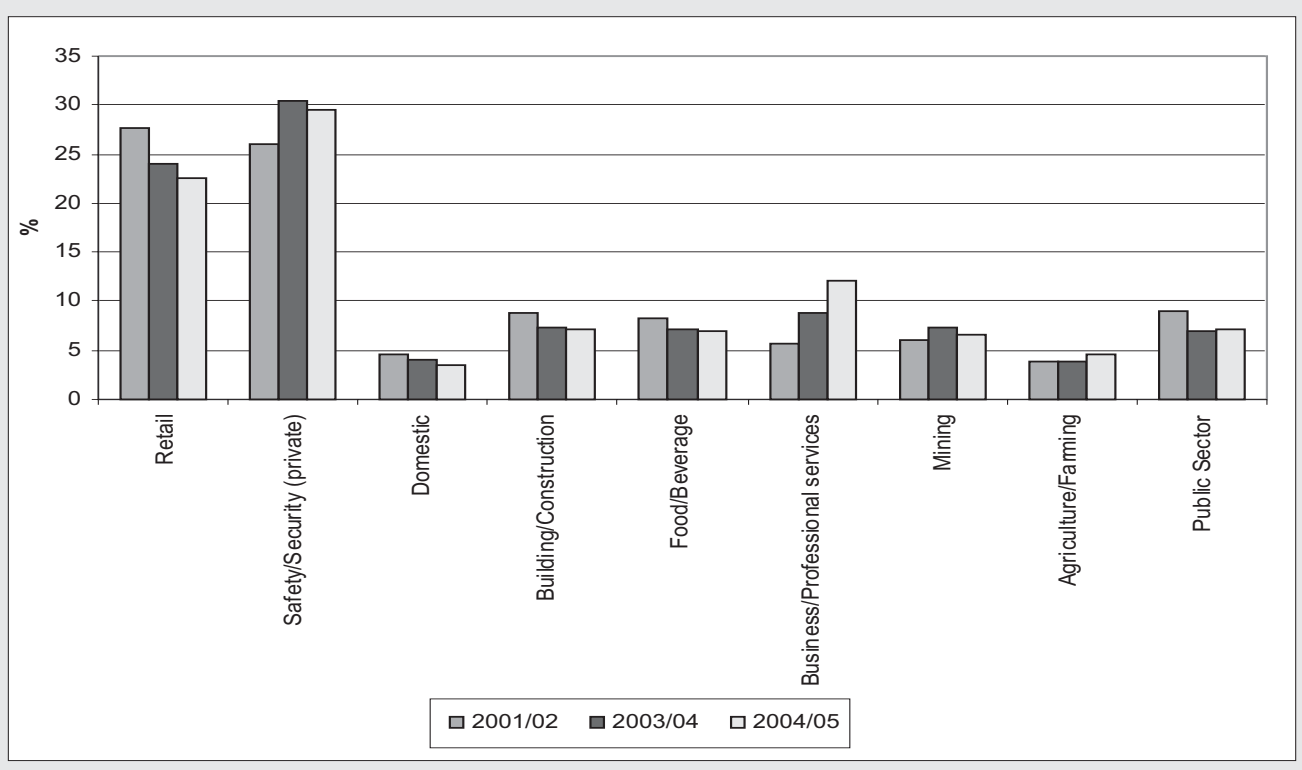




\section{Cases out of Jurisdiction}

Table 5: State of Jurisdiction, Total Numbers

\begin{tabular}{|l|r|r|r|r|r|r|}
\hline & \multicolumn{2}{|c|}{$\mathbf{2 0 0 1 / 0 2}$} & \multicolumn{2}{c|}{$\mathbf{2 0 0 3 / 0 4}$} & \multicolumn{2}{|c|}{ 2004/05 } \\
\hline & Frequency & Percent & Frequency & Percent & Frequency & Percent \\
\hline In & 74,699 & 67.57 & 81,650 & 64.63 & 82,417 & 65.27 \\
Out & 35,822 & 32.40 & 44,612 & 35.31 & 43,720 & 34.62 \\
\hline Condonation pending & 21 & 0.02 & 35 & 0.03 & 85 & 0.07 \\
\hline Unknown & 10 & 0.01 & 33 & 0.03 & 50 & 0.04 \\
\hline Case closed & 1 & 0.00 & 0 & 0 & 0 & 0 \\
\hline Total & $\mathbf{1 1 0 , 5 5 3}$ & $\mathbf{1 0 0 . 0}$ & $\mathbf{1 2 6 , 3 3 0}$ & $\mathbf{1 0 0 . 0}$ & $\mathbf{1 2 6 , 2 7 2}$ & $\mathbf{1 0 0 . 0}$ \\
\hline
\end{tabular}

A very significant proportion of cases referred to the CCMA are classified as being "out of jurisdiction". In 2004-5, this amounted to 34 per cent of referrals. This compares with 31 per cent in 2001-2002 and 35 per cent in 2002-2003. This classification covers cases where it is possible at the initial stage of referral to determine that the CCMA does not have jurisdiction in respect of the subject-matter of the dispute. This may be the case where the dispute should properly have been referred to the Department of Labour such as an underpayment under the BCEA or where the employer and employee concerned are covered by a bargaining council. A recent study has estimated that approximately 15,000 disputes are referred to bargaining councils (Tokiso 2005). In addition, cases in which the referral is incomplete may be classified as being out of jurisdiction. The CMS does not record any further information regarding these cases. 
Figure 11: Out of Jurisdiction Cases by Region

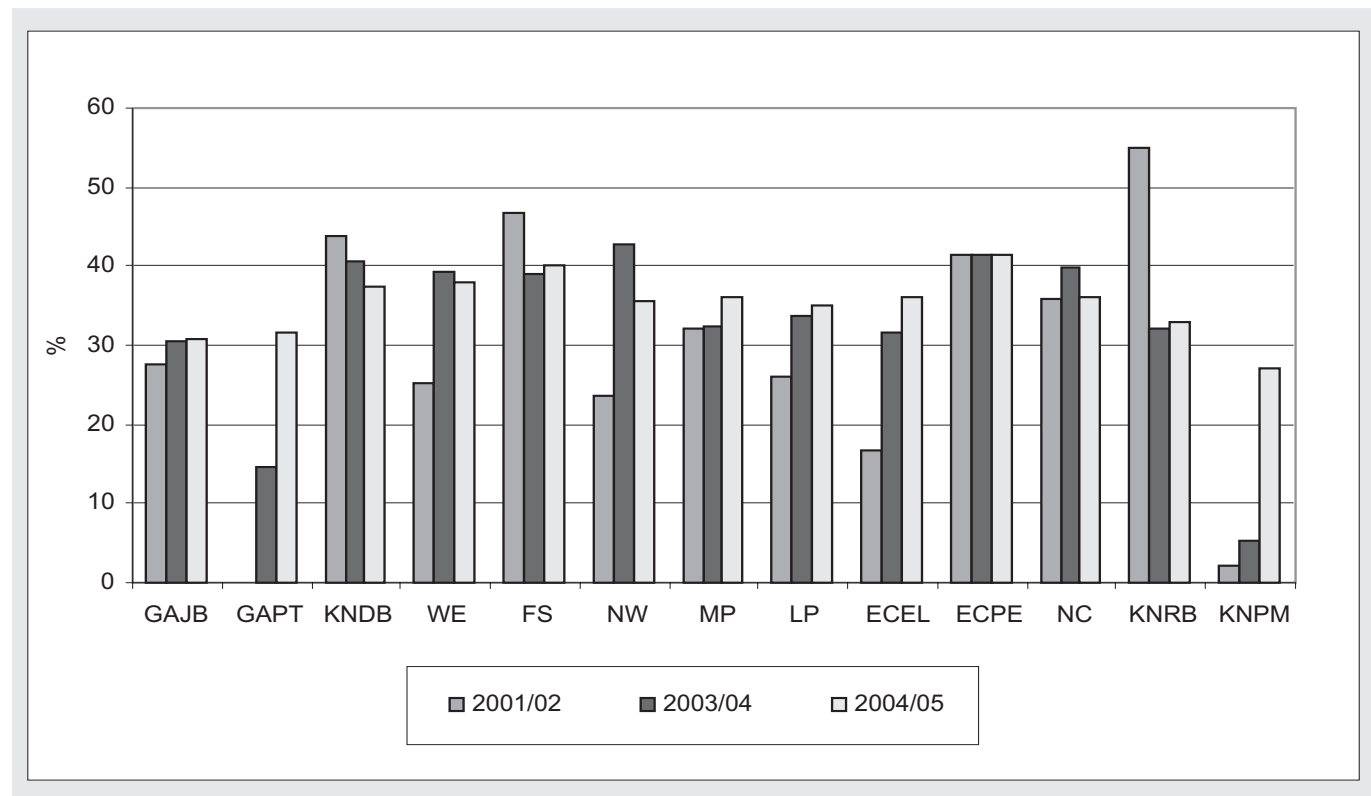




\section{Regional Variation}

In 2004-2005 the level of non-jurisdictional referrals in regions varied between 26 per cent (PMB) and 40 per cent (EL, FS).

\section{Figure 12: Out of Jurisdiction by Main Sector}

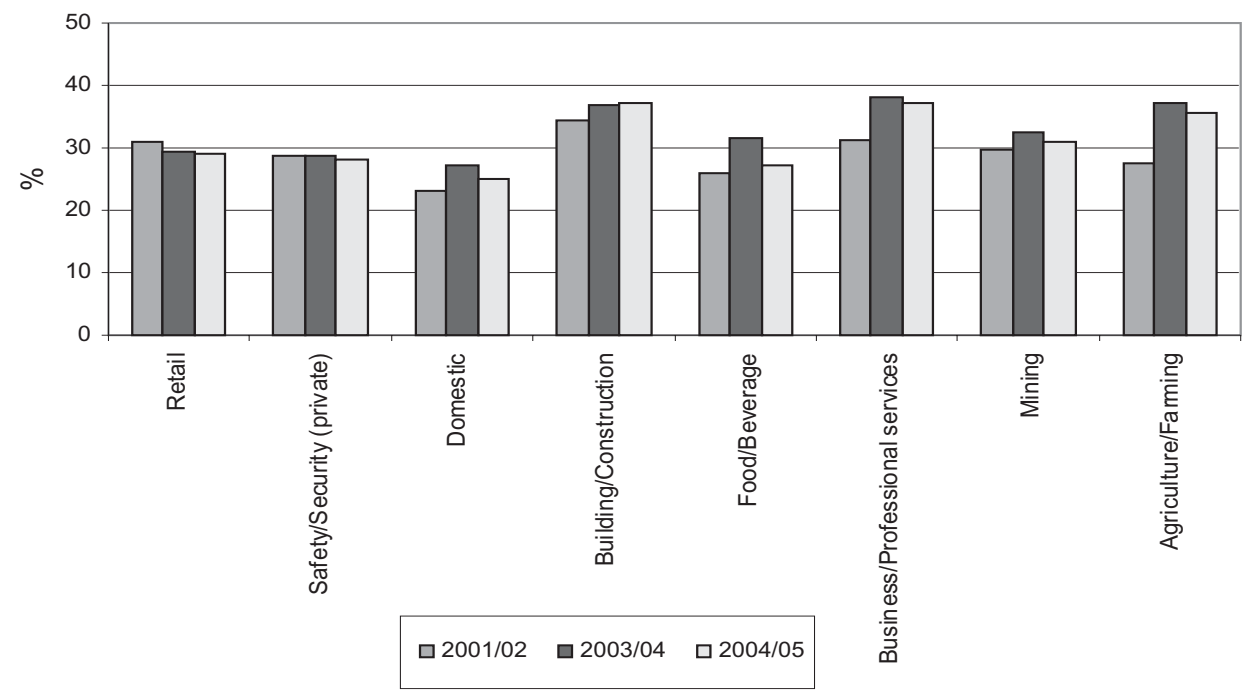

\section{Sectoral Variation}

There are significant sectoral variations. For instance, in 2004-5, the highest rate of "out of jurisdiction" referral are in sectors with bargaining councils (eg: metal 53\%, local government 41 per cent). The lowest rate of "out of jurisdiction" referrals are in respect of "high tech" sectors such as computing (16 per cent), media (20 per cent) and pharmaceutical (19 per cent). In a large sector with high levels of unskilled workers and high levels of unionisation such as mining the rate is 29.75 per cent while in a sector with a relatively low level of union density, such as agriculture, it is 27 per cent. 


\section{Comment}

The referral of a large number of "out of jurisdiction" cases to the CCMA imposes a considerable administrative burden on the CCMA. At the same time, the fact that such a high proportion are screened out at the referral stage prevents these cases from consuming more resources by being enrolled for conciliation or arbitration. One explanation is that the CCMA enjoys a relatively high profile compared to other dispute resolution agencies such as the Department of Labour and bargaining councils. The screening out of "out of jurisdiction " cases must be viewed in conjunction with the number of in limine applications being brought during proceedings discussed below.

\section{Table 6: Open Cases}

\begin{tabular}{|l|r|r|r|r|r|r|}
\hline & \multicolumn{2}{|c|}{$2001 / 02$} & \multicolumn{2}{|c|}{$\mathbf{2 0 0 3 / 0 4}$} & \multicolumn{2}{|c|}{ 2004/05 } \\
\hline & Frequency & Percent & Frequency & Percent & Frequency & Percent \\
\hline Case closed & 74,590 & 99.85 & 80,478 & 98.56 & 76,066 & 92.29 \\
\hline Outcome & 53 & 0.07 & 534 & 0.65 & 3,044 & 3.69 \\
Arrangement & 31 & 0.04 & 311 & 0.38 & 1,776 & 2.15 \\
Scheduled & 21 & 0.03 & 271 & 0.33 & 1,200 & 1.46 \\
\hline Activated & 4 & 0.01 & 56 & 0.07 & 331 & 0.40 \\
\hline Total & $\mathbf{7 4 , 6 9 9}$ & $\mathbf{1 0 0 . 0}$ & $\mathbf{8 1 , 6 5 0}$ & $\mathbf{1 0 0 . 0}$ & $\mathbf{8 2 , 4 1 7}$ & $\mathbf{1 0 0 . 0}$ \\
\hline
\end{tabular}

The CMS captures information about the status of disputes. The information is purely administrative ${ }^{5}$. Cases are considered to be closed when the dispute has been settled but can be opened again if a party decides to, for example, contest a particular ruling. If a case has not been closed it is open either waiting to be scheduled or waiting to be closed (Outcome) or to be "taken back to 'Activated' or 'Arrangement' to await rescheduling" (Review of Operations, 2004/2005, p. 13). 


\section{Unfair Dismissals and Unfair Labour Practices}

Table 7: Main Disputes under CCMA Jurisdiction ${ }^{6}$

\begin{tabular}{|l|r|r|r|r|r|r|}
\hline & \multicolumn{2}{|c|}{$\mathbf{2 0 0 1 / 0 2}$} & \multicolumn{2}{c|}{ 2003/04 } & \multicolumn{2}{c|}{ 2004/05 } \\
\hline & Frequency & Percent & Frequency & Percent & Frequency & Percent \\
\hline Unfair dismissal & 61,156 & 82.17 & 68,459 & 84.22 & 68,779 & 83.93 \\
Unfair labour practice & 4,525 & 6.08 & 4,986 & 6.13 & 5,094 & 6.22 \\
\hline Mutual interest & 1,858 & 2.50 & 1,070 & 1.32 & 1,341 & 1.64 \\
\hline Severance pay & 2,431 & 3.27 & 2,056 & 2.53 & 1,707 & 2.08 \\
\hline Cumulative & $\mathbf{6 9 , 9 7 0}$ & $\mathbf{9 4 . 0 2}$ & $\mathbf{7 6 , 5 7 1}$ & $\mathbf{9 4 . 2 0}$ & $\mathbf{7 6 , 9 2 1}$ & $\mathbf{9 3 . 8 7}$ \\
\hline
\end{tabular}

Figure 13: Unfair Dismissal Disputes by Region

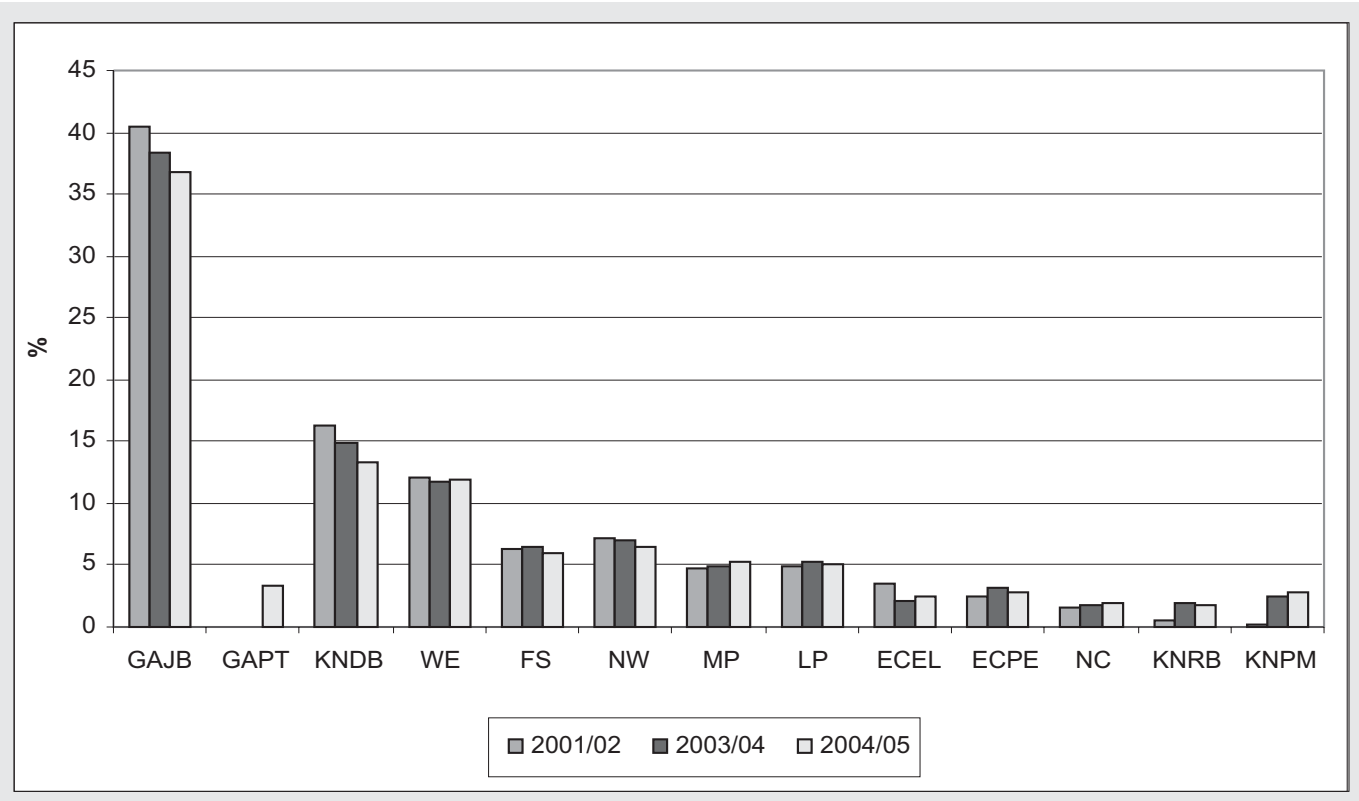

6 Similar to Table 4, referrals not considered as disputes are excluded from this calculation. Categories unfair dismissal and unfair labour practice subsume all relevant cases. 
Figure 14: Unfair Dismissal Disputes by Main Sector

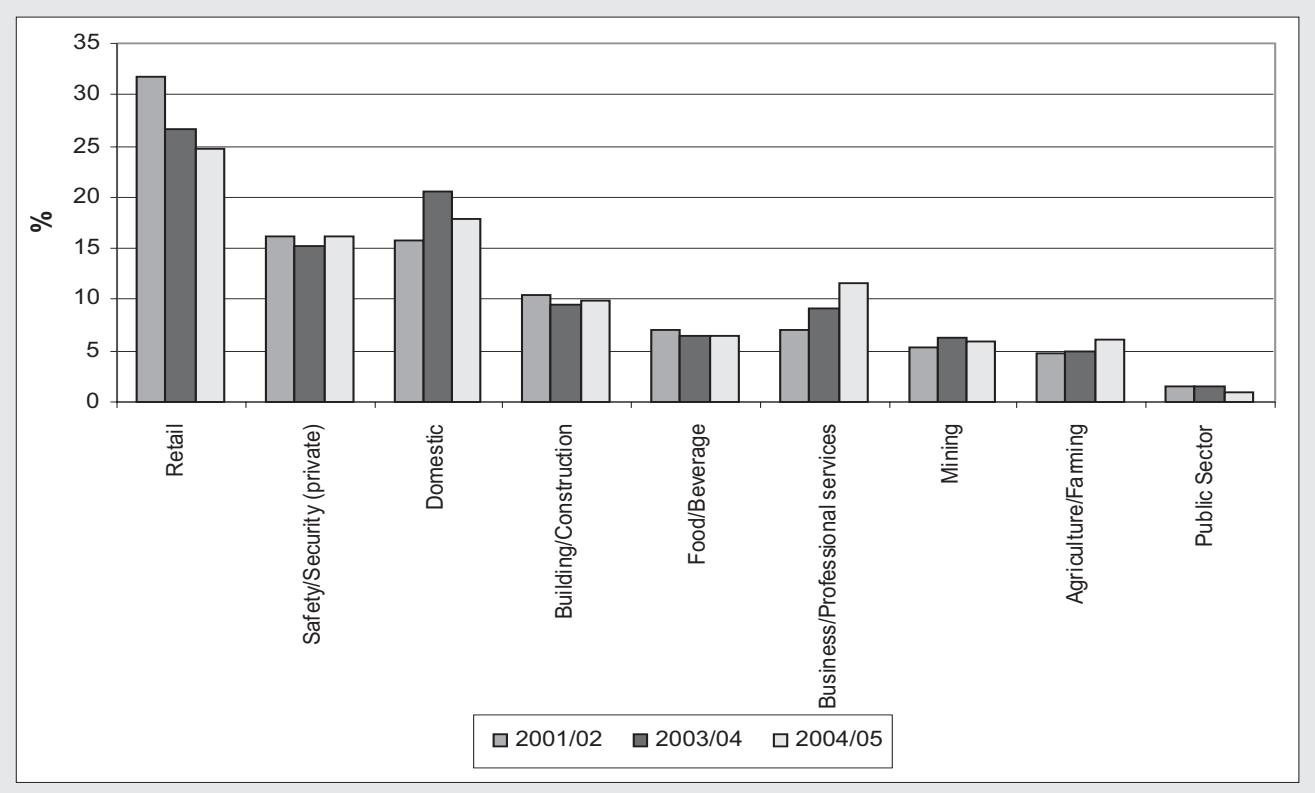

Figure 15: Unfair Labour Practice Disputes by Region

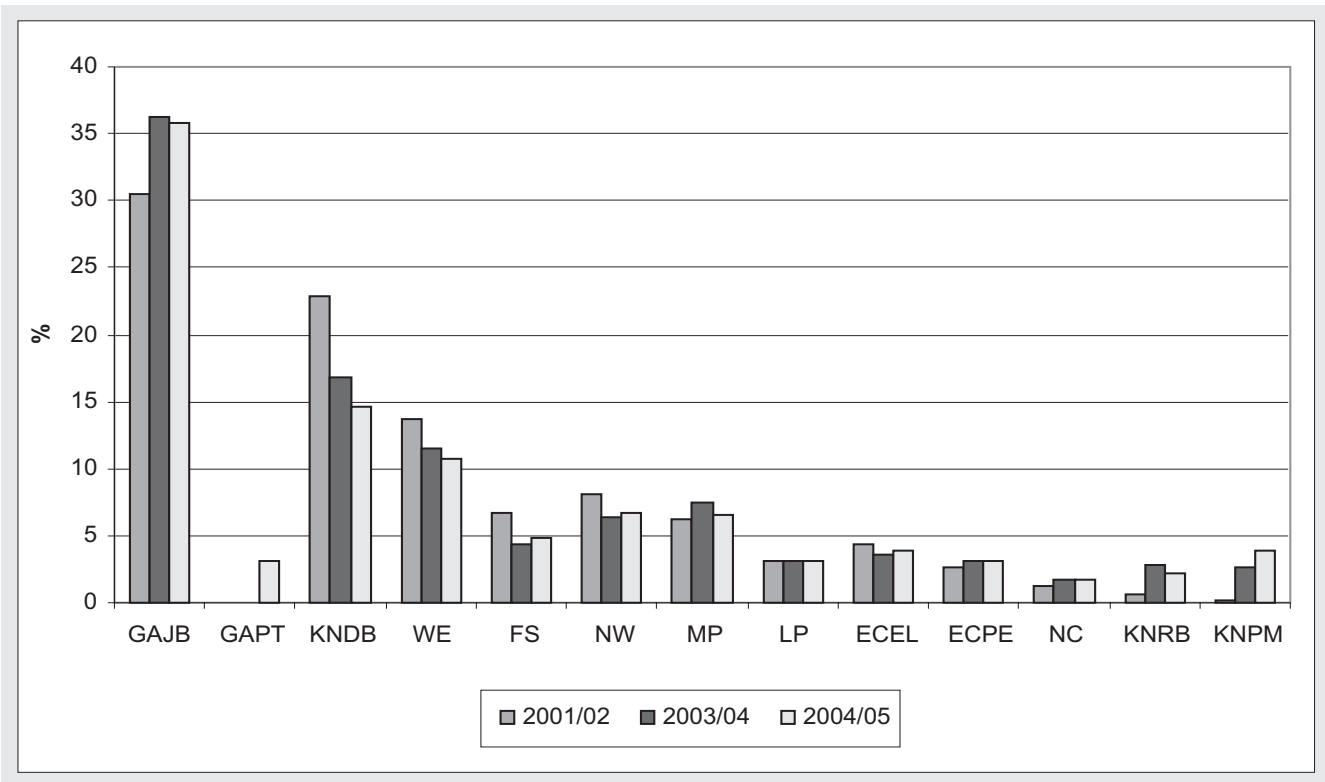


Figure 16: Unfair Labour Practice Disputes by Main Sector

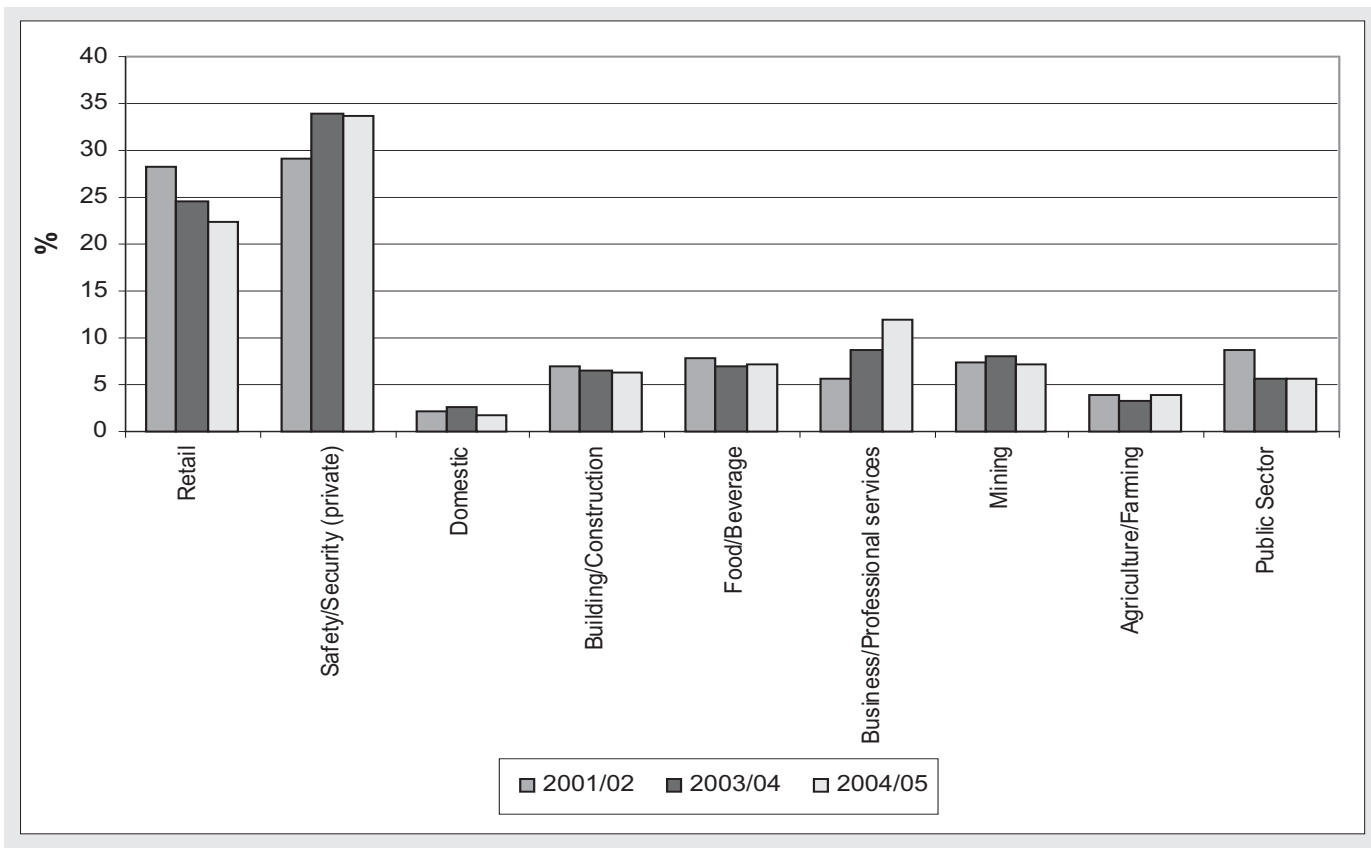

Figure 17: Unfair Dismissal Disputes by Region

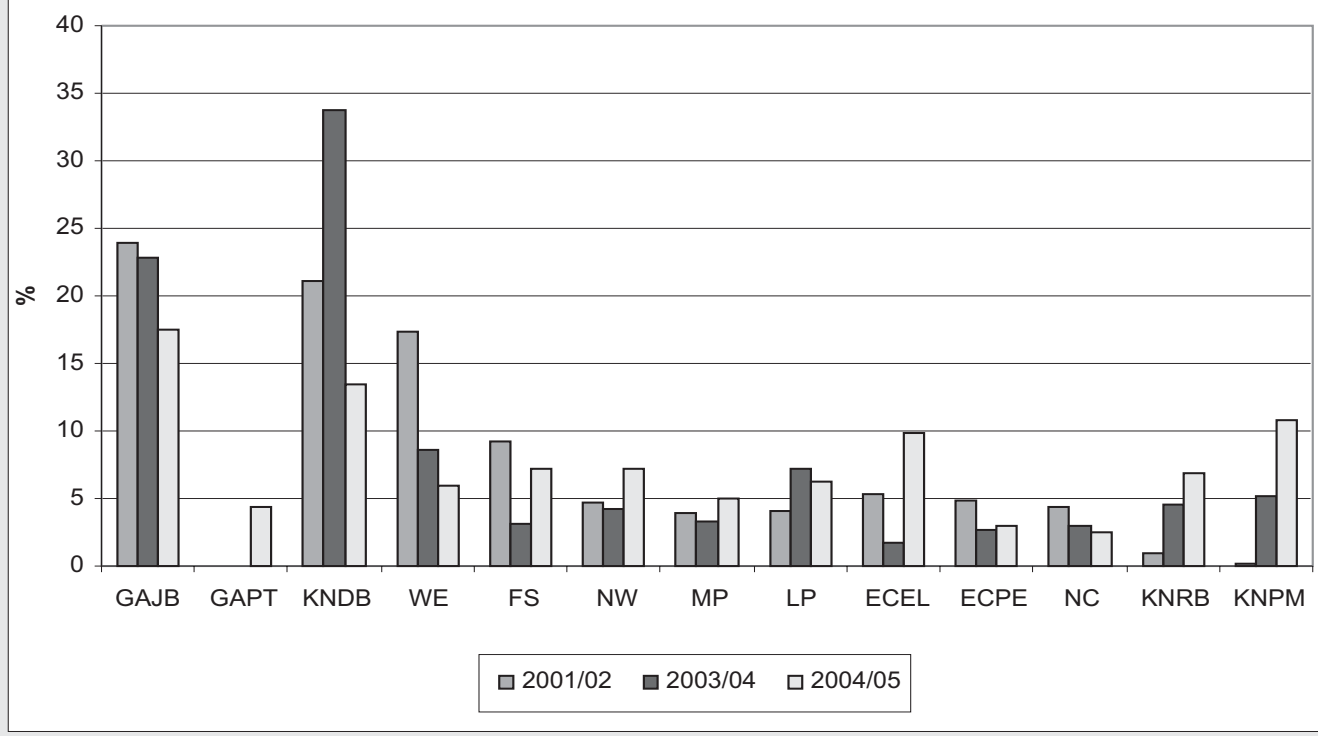


Figure 18: Unfair Labour Practice by Region

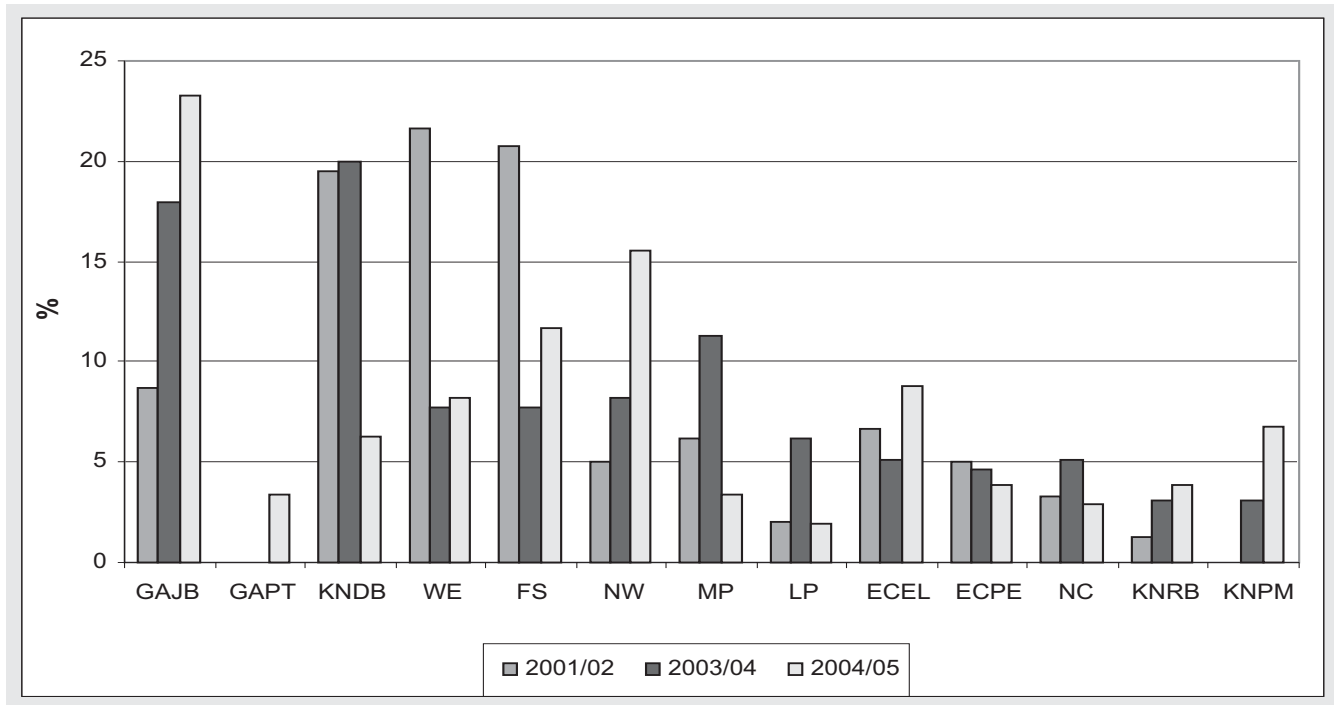

\section{Interpretation}

Regarding main sectors for all dismissal cases, the distribution across sectors is very similar to the sector-specific breakdown for all disputes (Table 2). The retail sector accounts for 20 per cent in 2001/02 and 18 per cent in 2004/05, respectively, followed by private security and the domestic sector. Those two sectors have traded places in terms of significance between the two years. The contribution from the building/construction sector as well as the manufacturing/processing branch of the food/beverage sector has been relatively stable over time. The share of dismissal disputes in business services has nearly doubled. Altogether, two thirds of all dismissal cases referred to the CCMA in $2004 / 05$ occurred in the seven main sectors.

It is notable that there has been an increase in the number of disputes referred to the CCMA from both the domestic worker sector and the agricultural sector. One issue for consideration is whether these figures indicate the response of employers to the introduction of sectoral determinations in the domestic and agricultural sectors. For the first time, sectoral determinations establishing minimum wages were extended to the domestic sector on 15 August 2002 and the farm worker sector in December 2002. While the CCMA has recorded figures indicating the number of referred cases which are related to the introduction of the sectoral determinations, these only account for a small part of the increase. An alternative explanation is that the publicity attendant on the introduction of the sectoral determinations, raised worker awareness of their rights in these sectors leading to a greater number of referrals. 
Further research would be required to ascertain whether the increase in the number of dismissals in these two sectors is attributable to the introduction of sectoral determinations. A 2004 paper concludes that the minimum wages for domestic workers are making a difference despite substantial non-compliance and that figures show that hours of work have decreased and earnings have increased without a negative employment response (Hertz 2004).

An initial attempt is made to make a comparison between referrals of unfair labour practices and unfair dismissal cases. This is done in the light of the argument advanced by Halton Cheadle that there is "no need for the judicial regulation through the prohibition of unfair labour practices of the selection decisions (hiring, training, promotion) and those aspects of discipline short of dismissal (suspension, demotion and other disciplinary measures)" (Cheadle 2005).

A comparison of Figures 14 and 16 indicates that there are significant sectoral variation in the referral of dismissal and unfair labour practice disputes. As might be expected, unfair labour practice referrals are insignificant in the domestic sector. The share of unfair labour practices referred by employees in safety/security (private) and the public sector is significantly higher than the share of dismissals referred from those sectors. This suggests that a range of factors might contribute to the level of unfair labour practice referrals in a particular sector.

\section{Unfair Labour Practice}

Table 8: Categories of Unfair Labour Practice

\begin{tabular}{|l|r|r|r|}
\hline & $\mathbf{2 0 0 1 / 0 2}$ & $\mathbf{2 0 0 3 / 0 4}$ & $\mathbf{2 0 0 4 / 0 5}$ \\
\hline Unfair labour practice (default) & 2,775 & 1,856 & 1,784 \\
\hline Unfair suspension or discipline & 866 & 1,531 & 1,694 \\
\hline $\begin{array}{l}\text { Unfair conduct regarding promotion, demotion, training, } \\
\text { benefits }\end{array}$ & 884 & 1,556 & 1,580 \\
\hline Unfair labour practice relating to probation & -- & 22 & 25 \\
\hline Unfair labour practice related to a protected disclosure & -- & 21 & 11 \\
\hline Total number & $\mathbf{4 , 5 2 5}$ & $\mathbf{4 , 9 8 6}$ & $\mathbf{5 , 0 9 4}$ \\
\hline
\end{tabular}

The categories of unfair labour practices are broken down into four categories. In each year, there is an almost equal referral of under the two main categories (unfair suspension and dismissal, promotion, demotion, training and benefits). Any analysis of the significance 
of the unfair labour practice jurisdiction will require a further disaggregation of the data within these broad categories. 


\section{Reasons for Dismissal}

\section{Table 9: Unfair Dismissal Cases ${ }^{7}$}

\begin{tabular}{|c|c|c|c|}
\hline & $2001 / 02$ & $2003 / 04$ & $2004 / 05$ \\
\hline Constructive dismissal & 799 & 2,190 & 2,759 \\
\hline Constructive dismissal related to transfer of contract [s197/s197A] & -- & 33 & 45 \\
\hline Dismissal due to participation in unprocedural strike & 1 & 13 & 32 \\
\hline Dismissal due to participation in/supported protected strike/protest & -- & 28 & 11 \\
\hline Dismissal related to a protected disclosure & -- & 2 & 4 \\
\hline Dismissal related to employee exercising right in terms of Act & -- & 49 & 58 \\
\hline Dismissal related to freedom of association & -- & 15 & 9 \\
\hline Dismissal related to incapacity & 2 & 1,516 & 1,861 \\
\hline Dismissal related to misconduct & 12 & 14,314 & 16,895 \\
\hline Dismissal related to pregnancy/maternity & -- & 133 & 138 \\
\hline Dismissal related to probation & -- & 137 & 116 \\
\hline Dismissal related to sectoral determination Domestic & -- & 87 & 32 \\
\hline Dismissal related to sectoral determination Farming & -- & 5 & 10 \\
\hline Dismissal related to transfer of contract [s197] & -- & 26 & 18 \\
\hline Dismissal related to unfair discrimination & -- & 156 & 125 \\
\hline Dismissals from closed shop & 3 & -- & - \\
\hline Failure to reinstate or re-employ in terms of any agreement & 78 & 81 & 75 \\
\hline Non-renewal of fixed term contract & -- & 162 & 138 \\
\hline Operational requirements & 222 & 3,143 & 3,341 \\
\hline Operational requirements (employer with more than 50 employees) & 5 & 175 & 173 \\
\hline Reason for dismissal not known & 7 & 17,008 & 20,036 \\
\hline Refusal to reinstate after maternity leave & 2 & 46 & 49 \\
\hline Refused to accept demand (matter of mutual interest) & -- & 3 & 3 \\
\hline Refused to join/refused membership closed shop & -- & 2 & 6 \\
\hline Refused to perform work of a striker & 1 & 3 & 1 \\
\hline Selective Re-employment & 1 & 5 & 7 \\
\hline Termination of contract with/without notice & 4 & 1,519 & 1,044 \\
\hline Unfair dismissal disputes (not further classified) & 60,029 & 27,611 & 21,794 \\
\hline Total number & 61,156 & 68,459 & 68,779 \\
\hline
\end{tabular}

7 To separate unfair dismissal cases from other types of referral, we rely on the definition of unfair dismissal cases used by the CCMA. The exact definition given in the data sometimes differs somewhat from the above given description. Only referrals that fall under CCMA jurisdiction are considered. 
The table shows that there has been a significant change in method of recording. In 2003/4 and 2004/05, a number of new categories have been added to the database. Specific reasons for a dismissal have been recorded in a greater number of cases. However, a significant number of cases are still recorded merely as unfair dismissals. For this reason, no meaningful comparison can be made between the years in respect of specific sub-categories.

Also, it is important to note how the type or reason of dismissal enters the CMS. The referring party indicates on the LRA form 7.11 the nature of the dispute. This information will enter the database. Even if new information about the type of dispute becomes available during the hearings, the data record will not necessarily be updated. An update of the nature of dispute might happen, but is not required. Hence, the reason for dismissal seems inaccurately recorded and a detailed analysis is not suggested. The analysis will only look at the aggregated (total number) of unfair dismissal cases. 


\section{Process of Dismissal Cases}

Table 10: Determinative Process of Dismissal Cases ${ }^{8}$

\begin{tabular}{|l|rr|rr|rr|}
\hline & \multicolumn{2}{|c|}{$\mathbf{2 0 0 1 / 0 2}$} & \multicolumn{2}{|c|}{$\mathbf{2 0 0 3 / 0 4}$} & \multicolumn{2}{c|}{$\mathbf{2 0 0 4 / 0 5}$} \\
\cline { 2 - 7 } & Frequency & Percent & Frequency & Percent & Frequency & Percent \\
\hline Pre-Conciliation & 2,829 & 4.63 & 3,056 & 4.46 & 2,305 & 3.35 \\
Conciliation & 27,716 & 45.32 & 16,157 & 23.60 & 12,567 & 18.27 \\
Arbitration & 22,376 & 36.59 & 26,458 & 38.65 & 23,517 & 34.19 \\
In Limine & 1,638 & 2.68 & 1,274 & 1.86 & 2,288 & 3.33 \\
Rescission & 1,042 & 1.70 & 2,763 & 4.04 & 2,378 & 3.46 \\
Taxation & 31 & 0.05 & 39 & 0.06 & 19 & 0.03 \\
Con/Arb & 3 & 0.00 & 13,873 & 20.26 & 22,109 & 32.14 \\
Facilitation & 3 & 0.00 & 70 & 0.10 & 66 & 0.10 \\
Training & 1 & 0.00 & -- & -- & -- & -- \\
Ruling Rescission & -- & -- & 9 & 0.01 & 19 & 0.03 \\
189A Facilitation & -- & -- & 79 & 0.12 & 72 & 0.10 \\
Pre-Dismissal & -- & -- & 2 & 0.00 & 2 & 0.00 \\
Arbitration & -- & -- & 2 & 0.00 & -- & -- \\
Review & -- & -- & 1 & 0.00 & -- & -- \\
Ballot & 5,515 & 9.02 & 4,676 & 6.83 & 3,437 & 5.00 \\
Unknown & $\mathbf{6 1 , 1 5 4}$ & $\mathbf{1 0 0 . 0 0}$ & $\mathbf{6 8 , 4 5 9}$ & $\mathbf{1 0 0 . 0 0}$ & $\mathbf{6 8 , 7 7 9}$ & $\mathbf{1 0 0 . 0 0}$ \\
\hline Total number & & & & &
\end{tabular}

Table 10 indicates the final process recorded for each dispute. For the vast majority of cases it reflects the type of process at which a particular dispute has been resolved. If the case had not been closed at the time the data was retrieved from the CMS, it indicates the current process that the dispute has read.

Cases resolved on the basis of 189A Facilitation refer to dismissals based on operational requirements for employers employing more than 50 employees. Facilitation relates to matters of mutual interest, organisational rights and wage disputes. Rescission means that a party applied for an award to be rescinded because it is believed that the award has an error, is ambiguous or has omitted certain information. Ruling rescission means a party has applied to have the ruling of rescission (as described earlier) rescinded.

8 For a regional and sectoral breakdown of the information in Table 10 see Tables A1-A6 in the Statistical Annex. 
This table indicates a single process in respect of each case. A number of noteworthy features:

a) the provision for con-arb introduced by the 2002 Amendments has been used extensively with 20 per cent (in 2003/4) and 32 per cent (in 2004/5) of cases being dealt with through con-arb proceedings.

b) there has been a significant rise in the number of cases in which in limine points are taken.

c) there has been a significant rise in the number of rescission applications.

d) there are a minimal number of taxations in any year.

The significance of these features is explored in greater detail below. 


\section{Hearings, Conciliation, Arbitration and Con-Arb}

\section{Conciliation: Number of Hearings}

Table 11: Conciliation: Number of Hearings

\begin{tabular}{|c|rr|rr|rr|}
\hline & \multicolumn{2}{|c|}{$\mathbf{2 0 0 1 / 0 2}$} & \multicolumn{2}{|c|}{$\mathbf{2 0 0 3 / 0 4}$} & \multicolumn{2}{c|}{ 2004/05 } \\
\cline { 2 - 7 } & Frequency & Percent & Frequency & Percent & Frequency $^{9}$ & Percent \\
\hline 1 & 24,571 & 88.65 & 13,647 & 84.46 & 10,513 & 83.66 \\
2 & 2,710 & 9.78 & 2,163 & 13.39 & 1,749 & 13.92 \\
3 & 365 & 1.32 & 270 & 1.67 & 259 & 2.06 \\
4 & 59 & 0.21 & 70 & 0.43 & 42 & 0.33 \\
5 & 9 & 0.03 & 5 & 0.03 & 4 & 0.03 \\
6 & 2 & 0.01 & 2 & 0.01 & -- & -- \\
\hline Total number & $\mathbf{2 7 , 7 1 6}$ & $\mathbf{1 0 0 . 0 0}$ & $\mathbf{1 6 , 1 5 7}$ & 100.00 & $\mathbf{1 2 , 5 6 7}$ & $\mathbf{1 0 0 . 0 0}$ \\
\hline
\end{tabular}

The vast majority of cases resolved at conciliation continue to be dealt with in a single conciliation meeting. (As pointed out above, these figures only refer to cases in which conciliation was the final (determinative) stage).

9 The difference in figures is explained by the use of Con/Arbs in 2004/05. See Table 10. 


\section{Arbitration: Number of Hearings}

However, the statistics shown in Table 12 indicate that less than 10 per cent of all arbitrations are settled in a single meeting. 55 per cent of all arbitrations are dealt with in two hearings. ${ }^{10}$ The average length of arbitration hearings shows a high level of consistency.

Table 12: Arbitration: Number of Hearings

\begin{tabular}{|c|rr|rr|rr|}
\hline & \multicolumn{2}{|c|}{$\mathbf{2 0 0 1 / 0 2}$} & \multicolumn{2}{|c|}{$\mathbf{2 0 0 3 / 0 4}$} & \multicolumn{2}{|c|}{$\mathbf{2 0 0 4 / 0 5}$} \\
\cline { 2 - 7 } & Frequency & Percent & Frequency & Percent & Frequency & Percent \\
\hline 1 & 1,790 & 8.00 & 1,583 & 5.98 & 1,916 & 8.15 \\
3 & 12,364 & 55.26 & 14,633 & 55.31 & 13,110 & 55.75 \\
4 & 4,488 & 20.06 & 5,287 & 19.98 & 4,593 & 19.53 \\
5 & 2,066 & 9.23 & 3,026 & 11.44 & 2,757 & 11.72 \\
6 & 874 & 3.91 & 1,175 & 4.44 & 775 & 3.30 \\
7 & 422 & 1.89 & 464 & 1.75 & 264 & 1.12 \\
8 & 189 & 0.84 & 170 & 0.64 & 73 & 0.31 \\
9 & 90 & 0.40 & 73 & 0.28 & 26 & 0.11 \\
10 & 53 & 0.24 & 29 & 0.11 & 2 & 0.01 \\
11 & 21 & 0.09 & 11 & 0.04 & 1 & 0.00 \\
12 & 12 & 0.05 & 3 & 0.01 & -- & -- \\
14 & 4 & 0.02 & 3 & 0.01 & -- & -- \\
13 & 1 & 0.00 & 1 & 0.00 & -- & -- \\
15 & -- & -- & -- & -- & -- & -- \\
24 & 1 & 0.00 & -- & -- & -- & -- \\
\hline Total number & $\mathbf{2 2 , 3 7 6}$ & $\mathbf{1 0 0 . 0 0}$ & $\mathbf{2 6 , 4 5 8}$ & $\mathbf{1 0 0 . 0 0}$ & $\mathbf{2 3 , 5 1 7}$ & $\mathbf{1 0 0 . 0 0}$ \\
\hline
\end{tabular}

10 This outcome is unexpected, but has been verified with the CCMA. 


\section{Con/Arb: Number of Hearings}

The 2002 Amendments (in section 191(5A)) provided for a "con-arb" hearing in which the arbitration could be conducted immediately on conclusion of the arbitration hearing. As Tables A1-A3 indicate there are very significant regional varieties in the extent to which con-arb is utilised. These reflect differing administrative policies in the different regions. It is not known to what extent these figures are influences by parties objecting to con-arb proceedings.

In 2003/4 seventy-two per cent were finalised in a single hearing and in 2004/5 sixty-six per cent were finalised in one hearing. The Act provides that, except in cases concerning probation, either party has a right to object to the arbitration continuing immediately on completion of the conciliation phase. The statistics, do not reflect the extent to which objections are made. The fact that the right to object is recorded in the Act precludes the CCMA adopting any arrangements to deal with this problem. The high number of conarbs resolved in a single hearing contrasts strongly with the very much lower figure (10 per cent) for arbitration. The efficiency of con-arb is also reflected in the shorter average 'turnaround' times discussed below.

Table 13: Con/Arb: Number of Hearings

\begin{tabular}{|c|r|r|r|r|r|r|}
\hline \multirow{2}{*}{} & \multicolumn{2}{|c|}{$2001 / 02$} & \multicolumn{2}{c|}{$2003 / 04$} & \multicolumn{2}{c|}{$2004 / 05$} \\
\cline { 2 - 7 } & Frequency & Percent & Frequency & Percent & Frequency & Percent \\
\hline 1 & 1 & 33.33 & 10,058 & 72.50 & 14,702 & 66.50 \\
2 & 2 & 66.67 & 3,348 & 24.13 & 6,640 & 30.03 \\
3 & -- & -- & 404 & 2.91 & 681 & 3.08 \\
4 & -- & -- & 50 & 0.36 & 66 & 0.30 \\
5 & -- & -- & 10 & 0.07 & 20 & 0.90 \\
6 & -- & -- & 2 & 0.01 & -- & -- \\
7 & -- & -- & 1 & 0.01 & -- & -- \\
\hline Total number & 3 & 100.00 & 13,873 & 100.00 & $\mathbf{2 2 , 1 0 9}$ & 100.00 \\
\hline
\end{tabular}




\section{Outcome of Dismissal Cases}

Table 14: Outcome of Unfair Dismissal Cases ${ }^{11}$

\begin{tabular}{|r|rr|rr|rr|}
\hline & \multicolumn{2}{|c|}{$2001 / 02$} & \multicolumn{2}{|c|}{$\mathbf{2 0 0 3 / 0 4}$} & \multicolumn{2}{|c|}{$\mathbf{2 0 0 4 / 0 5}$} \\
\cline { 2 - 7 } & Frequency & Percent & Frequency & Percent & Frequency & Percent \\
\hline SETTLED & 21,532 & 35.21 & 26,251 & 38.34 & 25,259 & 36.73 \\
NOT SETTLED AND COMPLETED & 14,635 & 23.93 & 5,923 & 8.66 & 4,805 & 6.99 \\
CONTINUING IN PROCESS & 335 & 0.55 & 524 & 0.76 & 977 & 1.41 \\
Arbitration Award Rendered & 10,921 & 17.86 & 11,022 & 16.10 & 10,720 & 15.59 \\
Default Award & 1,389 & 2.27 & 4,369 & 6.38 & 5,630 & 8.19 \\
Settlement Agreement Made an & 4 & 0.01 & 154 & 0.22 & 226 & 0.33 \\
Arbitration Award & & & & & & \\
Pending Labour Court Appeal & -- & -- & 2 & 0.00 & -- & - \\
Not Rescinded & 832 & 1.36 & 2,355 & 3.44 & 1,564 & 2.27 \\
Ruling Not Rescinded & -- & -- & 8 & 0.01 & 16 & 0.02 \\
Case Dismissed: Non-Attendance & 3,427 & 5.60 & 11,466 & 16.75 & 11,456 & 16.66 \\
Out of Jurisdiction & 1,741 & 2.85 & 45 & 0.07 & 20 & 0.03 \\
In Jurisdiction & 637 & 1.04 & 757 & 1.11 & 1,346 & 1.96 \\
Rescinded & 115 & 0.19 & 264 & 0.39 & 400 & 0.58 \\
Completed & 35 & 0.06 & 172 & 0.25 & 134 & 0.19 \\
Ruling Rescinded & -- & -- & 1 & 0.00 & 2 & 0.00 \\
Unknown & 5,553 & 9.08 & 5,146 & 7.52 & 6,224 & 9.05 \\
\hline Total number & 61,156 & 100.00 & 68,459 & 100.00 & 68,779 & 100.00 \\
\hline
\end{tabular}

Possible outcomes of unfair dismissal cases are given in Table 14. The outcome "Not settled and completed" refers to cases that will have to go to a different forum. Parties will most likely not come back to the CCMA to resolve the respective dispute.

11 Categories in capital letters indicate that several outcomes have been summed up. For a regional and sectoral breakdown of the information in this table see Tables A7-A12 in the Statistical Annex. 


\section{Non-Attendance by Parties}

It is a striking feature of the operation of the CCMA that a large number of disputes involve failure of one of the parties to attend. Where it is the employer party who has failed to attend this, it is reflected as a 'default' award; where it is the employee party, it is reflected as case dismissed - non-attendance. Significantly, the number of cases falling under these two headings is very much lower for the 2001/2 eight per cent than in the two latter years where it is approximately 25 per cent. Tables A7-A9 show that there are very significant regional variations in non-attendance by parties. The highest level of default judgments are found in the domestic sector; with very low levels in sectors such as ruling which are dominated by large employers. Dismissal of cases for non-attendance by applicants is relatively consistent between sectors (Tables A10-12).

\section{Pre-Dismissal Arbitration}

The 2002 amendments to the LRA introduced a provision for pre-dismissal arbitration where a disciplinary hearing is in effect conducted by an arbitrator's reply by the CCMA. This amendment was motivated by the logic that it would allow for a single hearing to replace the internal hearing followed by an arbitration. The award made it a pre-dismissal arbitration at the same status as that of an ordinary arbitration. As Table 10 indicates the statistics shows the impact of this amendment has been marginal with very few predismissal arbitrations conducted in either $2003 / 4$ or 2004 . The reason for this is the requirement for agreement between employer and employee over the hearing of a predismissal arbitration and the fact that the employer is required to pay the fees of an arbitrator.

\section{In Limine Points}

An in limine application refers to a legal proceeding where the party seeks to have a case dismissed on a technical basis that does not relate to the merits of the case. Instances where in limine proceedings could be brought would be to allege that a case was brought outside of the applicable time period or not in accordance with the appropriate procedure or that the applicant is not an employee or was not dismissed but in fact resigned. The CMS database reflects the number of cases in which an in limine application disposes of the matter (rather than how many are brought). As Table 10 indicates, there is a significant increase in the number of cases resolved in this manner. 


\section{Sectoral Variations}

There are no sectors in which the number of in limine applications are significantly disproportionate to the number of cases in that sector. However, between the periods, there is a substantial increase in the number of in limine applications brought in respect of domestic workers.

\section{Regional Variations}

The distribution of in limine applications is consistent with the distribution of arbitration hearings between the different regional offices.

\section{Comment}

The increasing number of in limine applications could be the result of difficulties in the screening of cases. A further more substantive explanation could be that it is the result of increasing difficulties in categorising employment relationships.

A series of studies by the ILO suggests that internationally disputes or uncertainty concerning the legal nature of the employment relationship are increasingly frequent. They attribute this to two factors: the rise of strategies to disguise employment and the rise of objectively ambiguous employment relationships (ILO (2003 and 2005)). A research project by Department of Labour on the changing nature of work and atypical forms of employment changes in the labour market have taken the form of externalisation driven by an exponential increase in the incidence of labour broking (temporary employment services) (Department of Labour 2004).

In the light of this, consideration should be given to whether the CMS should include fields to identify non-standard employment, in particular whether persons are employed through a temporary employment service. 
Table 15: Breakdown of Awards Referred

\begin{tabular}{|c|rr|rr|rr|}
\hline & \multicolumn{2}{|c|}{$\mathbf{2 0 0 1 / 0 2}$} & \multicolumn{2}{|c|}{$\mathbf{2 0 0 3 / 0 4}$} & \multicolumn{2}{|c|}{$\mathbf{2 0 0 4 / 0 5}$} \\
\cline { 2 - 8 } & Frequency & Percent & Frequency & Percent & Frequency & Percent \\
\hline Employer & 5,135 & 47.02 & 5,664 & 51.39 & 5,765 & 53.78 \\
Employee & 4,847 & 44.38 & 4,771 & 43.29 & 4,427 & 41.30 \\
Other $^{12}$ & 933 & 8.54 & 537 & 4.87 & 285 & 2.66 \\
Unknown & 6 & 0.05 & 50 & 0.45 & 243 & 2.27 \\
\hline Total number & $\mathbf{1 0 , 9 2 1}$ & $\mathbf{1 0 0 . 0 0}$ & $\mathbf{1 1 , 0 2 2}$ & $\mathbf{1 0 0 . 0 0}$ & $\mathbf{1 0 , 7 2 0}$ & $\mathbf{1 0 0 . 0 0}$ \\
\hline
\end{tabular}

The CMS records the number of cases in respect of which arbitration awards are given and breaks this down between those that are given in favour of employees and those that are in favour of employers.

Table 15 provides a breakdown of arbitration awards for unfair dismissal cases. The Table also shows that the proportion of awards in favour of employers has been steadily increasing from 47 per cent to almost 54 per cent.

The database also provides information about the status of compensation (Yes/No) and the amount of the compensation. However, these items do not reflect mandatory fields in the CMS, and the records are incomplete. Additionally, the data capture problems as the database reflects that both employees and employers seem to receive compensation payments. In agreement with CCMA, all compensation amounts recorded in the data are assumed to be awarded to employees. Table 16 provides an overview.

With effect from the financial year 2005-6, the CMS will also seek to record the nature of awards in dismissal cases, in particular, whether reinstatement or re-employment was ordered and the amount of any compensation that is awarded. However, for years prior to the 2005-6 financial year, it is therefore necessary to analyse individual awards to determine the relief granted to employees. Such an analysis was beyond the terms of this project.

12 'Other' refers to cases that were deemed to be out of jurisdiction at the arbitration phase. 


\section{Sectoral Variations}

The figures obtained form the CMS do not show any significant variation between economic sectors in the outcome of arbitrations.

\section{Regional Variations}

A break-down of arbitration outcomes by region reveals a variation in the outcome of awards in favour of employees and employers is striking ranging from Durban (69 per cent for employees; 29 per cent for employees) to Cape Town (47 for employees; 42 per cent for employees). In the previous financial year, the range was even greater: Durban (71 per cent for employees; 25 per cent for employers) to Cape Town (42 per cent for employees; 52 per cent for employers) ${ }^{13}$

Table 16: Compensation Amount

\begin{tabular}{|ccc|ccc|ccc|}
\hline \multicolumn{2}{|c|}{$2001 / 02$} & \multicolumn{3}{c|}{ 2003/04 } & \multicolumn{3}{c|}{ 2004/05 } \\
\hline Mean & Median & Std. Dev. & Mean & Median & Std. Dev. & Mean & Median & Std. Dev. \\
22,135 & 9,000 & 65,516 & 18,938 & 7,600 & 105,673 & 20,671 & 7,575 & 193,824 \\
\hline \multicolumn{2}{|c|}{ Observations: 3,158} & \multicolumn{2}{|c|}{ Observations: 4,239} & \multicolumn{2}{c|}{ Observations: 4,042 } \\
\hline
\end{tabular}

As the difference between the mean and median amount as well as the standard deviation indicates, there is also a lot of variation across compensation payments. This is probably explained by the fact that the "cap" on jurisdiction is expressed in 12 months' earnings. As a result, the compensation that an employee may receive in monetary terms is dependent on their incomes. The high standard deviation is probably a result of those cases in which high-earning employees receive financial compensation. It would be informative to analyse the variation across sectors, regions and type of disputes. At the moment, however, such an exercise is likely to yield biased results as the sample size is too small. A comprehensive survey of court decision and arbitration awards dealing with the determination of compensation concludes that "there has been very little attempt to formulate principles as to how the compensation to be paid should be determined" (Mischke 2005). Factors that are taken into account in determining 'just and equitable'

13 Based on CCMA Annuals Operations Report (2004/5). 
compensation include: the employees length of service, the employee's prospect of finding alternative employment, the circumstances and consequences of the dismissal; whether the dismissal was procedurally or substantively unfair. The employer's circumstances, including the size of the employer's business is rarely used as a consideration. Mischke suggests that the most common award of compensation is six months' wages.

\section{Reviews}

The CCMA is subject to the review jurisdiction of the Labour Court. Statistics on reviews are not retained as part of the CMS system. While the CCMA is cited as a party to the review, its policy is, accepted in exceptional cases not to oppose reviews. Figures available for the period April 2003 to February 2004 contained in the Table 17 indicate that 1893 reviews were instituted in this period. This approximates to almost 1 in 10 arbitration awards being subjected to review.

Table 17: Reviews Recorded April 2003 - February 2004 ${ }^{14}$

\begin{tabular}{|l|l|l|}
\hline Eastern Cape & 86 & $(4,543)$ \\
Free State & 62 & $(3,275)$ \\
Gauteng & 1114 & $(58,848)$ \\
Kwazulu Natal & 213 & $(11,251)$ \\
Limpopo & 60 & $(3,169)$ \\
Mpumulanga & 94 & $(4,965)$ \\
Northern Cape & 16 & $(0,845)$ \\
North West & 113 & $(5,969)$ \\
Western Cape & 135 & $(7,131)$ \\
TOTAL: & & \\
\hline
\end{tabular}

No comprehensive figures are available in respect of how many of these reviews were pursued to the point of a decision in the Labour Court or Labour Appeal Court. This is significant as many reviews are instituted for the purposes of delaying implementation of judgments. In Gauteng, 58 per cent of reviews were instituted whereas only 48 per cent of arbitration awards were rendered there. Read with the statistics for rescission applications this may again indicate a tendency to a more legalistic approach in Gauteng.

14 Source of information: CCMA Dispute Resolution Department. 
Recently Judge Dhaya Pillay in the Labour Court case of Shoprite Checkers (Pty) Ltd V CCMA and others (Unreported; Case No.: P394/2004) in a judgment delivered on 5 May 2005 made certain wide ranging comments:

"[22] In my view there is an emerging consensus in the industrial relations community that the systems and institutions established under the LRA eight years ago, in particular the CCMA and the labour courts, are not functioning optimally. Originally, these institutions were conceived as providing a quick, efficient and free public service. The CCMA was devised as a one stop dispute resolution shop. Dismissals which constitute the bulk of the disputes were meant to be resolved by a two stage process of conciliation and arbitration. An attempt was made by introducing the con-arb in the 2002 amendment to the LRA to make the two stage process seamless. As it is used so infrequently, it has not succeeded in improving the efficiency of dispute resolution.

[23] Whereasthereviewwasintendedtobeexceptional, itisnowfastbecoming the norm. This change was brought about somewhat unexpectedly when the new Constitution (Act 108 of 1996), which was adopted after the LRA was drafted, wassointerpreted by the LabourAppealCourtasto introduce rationality as an additional ground of review. However, the rationality test has become so distorted, that it has blurred the distinction between appeals and reviews.

[24] A critical stage has been reached in our labour law jurisprudence. A serious attempt must be made to restore dispute resolution to the two stage process as originally intended, instead of the five stage process that it is fast becoming. If this is not done urgently the efficiency of the CCMA and the labour courts are at stake. Needless to say the impact of that on the economy can only be adverse. To reverse the current trends, responsibility rests on the litigants to be circumspect about the cases they prosecute to avoid abusing the free dispute resolution services. Equally, the courts have a duty to discourage appeals that present in the guise of reviews."

The writer John Grogan has commented that the failure by the LRA to specify a time limit for the conclusion of matters set in motion by review proceedings is a "gaping omission" (Grogan 2005). This enables employers to utilise a review to stave off the enforcement of awards. While the Labour court has on several occasions expressed frustration with this practice. One of the principal causes of these delays can be the time period taken by the CCMA or bargaining councils to file the record of review proceedings. 


\section{Taxation}

As Table 10 indicates, the number of taxation hearings is virtually negligible. This is because arbitrators are only able to award costs against unsuccessful litigants in exceptional cases. Proposals in the 2000 LRA Amendment Bill to expand the discretion of arbitrators to make costs awards as a disincentive for the inappropriate referral of cases to the CCMA were not included in the amending Act.

\section{Certification of Awards}

Section 143 of the LRA permits CCMA awards to be enforced as if they were Labour Court orders once they have been certified. Prior to this amendment, a separate application in the Labour Court had to be made to enforce an award. Certification is therefore required where an employer fails to comply voluntarily with an arbitration award. The number of section 143 certificates is not recorded as part of the CMS and comprehensive information on this issue could not be obtained. The number of certifications is an indication of the extent to which awards are not voluntarily complied with. 


\section{Indicators of Administrative Efficiency ${ }^{15}$}

\section{Conciliation: Average Number of Days between Referral and} Activation Date

Table 18: Conciliation: Average Turnaround Times (Referral to Activation)

\begin{tabular}{|l|r|r|r|}
\hline & $\mathbf{2 0 0 1 / 0 2}$ & $\mathbf{2 0 0 3 / 0 4}$ & $\mathbf{2 0 0 4 / 0 5}$ \\
\hline By region: & & & \\
ECEL & 4.5 & 8.3 & 8.5 \\
ECPE & 4.8 & 0.9 & 3.3 \\
FS & 3.2 & 3.7 & 3.7 \\
GAJB & 5.2 & 13.6 & 7.5 \\
GAPT & -- & 128.0 & 12.2 \\
KNDB & 2.2 & 1.1 & 2.1 \\
KNPM & 1.2 & 0.6 & 5.0 \\
KNRB & 2.6 & 1.1 & 5.0 \\
LP & 2.8 & 11.2 & 11.2 \\
MP & 11.2 & 8.4 & 6.2 \\
NC & 8.3 & 3.0 & 9.0 \\
NW & 15.4 & 14.4 & 14.9 \\
WE & 9.9 & 5.9 & 5.0 \\
By main sector: & & & \\
Agriculture/Farming & 9.1 & 9.3 & 8.9 \\
Building/Construction & 4.8 & 9.4 & 6.5 \\
Business/Professional services & 6.2 & 10.8 & 8.5 \\
Domestic & 4.1 & 9.9 & 6.8 \\
Food/Beverage & 7.1 & 9.2 & 6.4 \\
Mining & 8.2 & 10.0 & 10.0 \\
Retail & 5.7 & 7.9 & 6.4 \\
Safety/Security (private) & 5.0 & 9.5 & 6.1 \\
\hline National average & 5.9 & 9.3 & 7.0 \\
\hline
\end{tabular}

15 Occasionally, the dates recorded at the CMS contradict each other. For example, the activation date would date farther back than the referral date. This led to individual negative turnaround times which were excluded from the calculation of the average turnaround times. 
The time between referral date and activation date reflects the time needed to complete information. The 30 day period to resolve the dispute only commences after a case has been activated.

Figure 19: Conciliation: Average Turnaround (Referral to Activation) Times by Region ${ }^{16}$

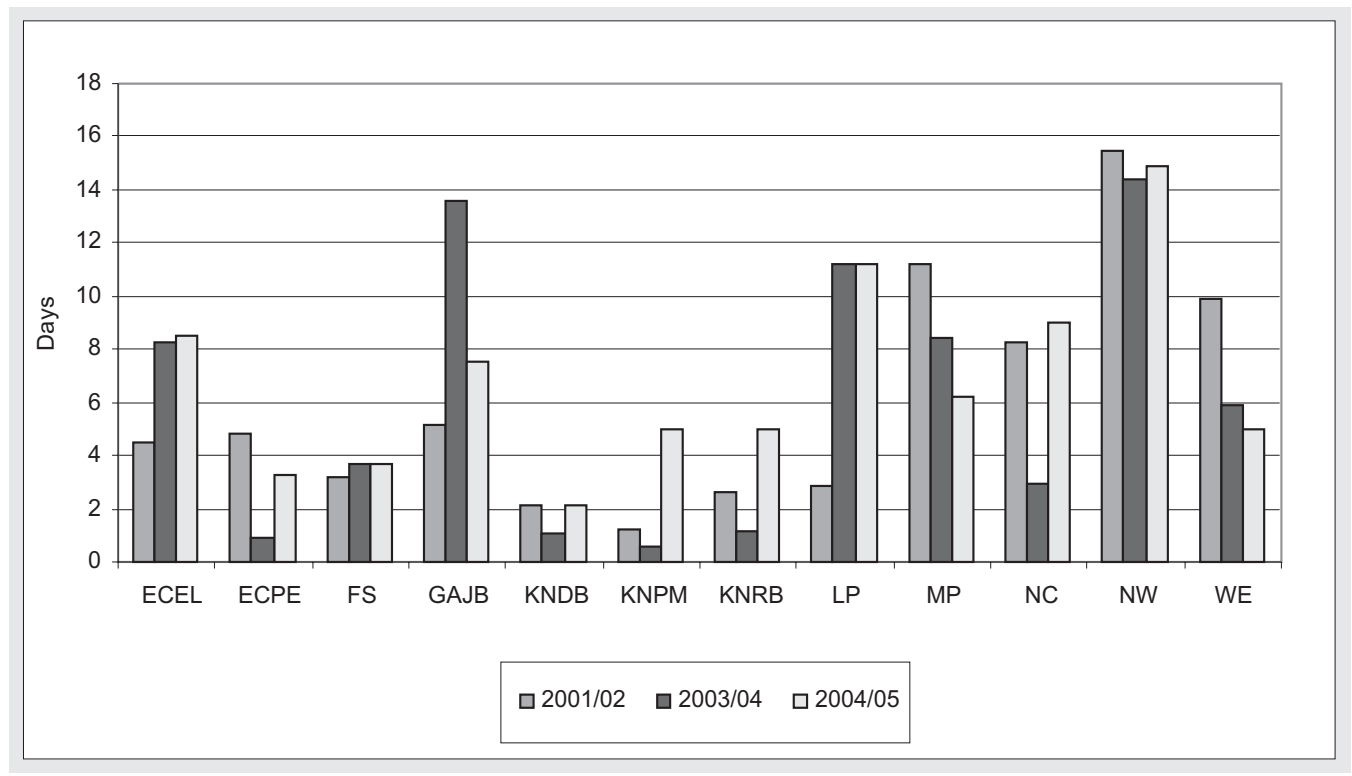

Figure 20: Conciliation: Average Turnaround Times (Referral to Activation) by Main Sector

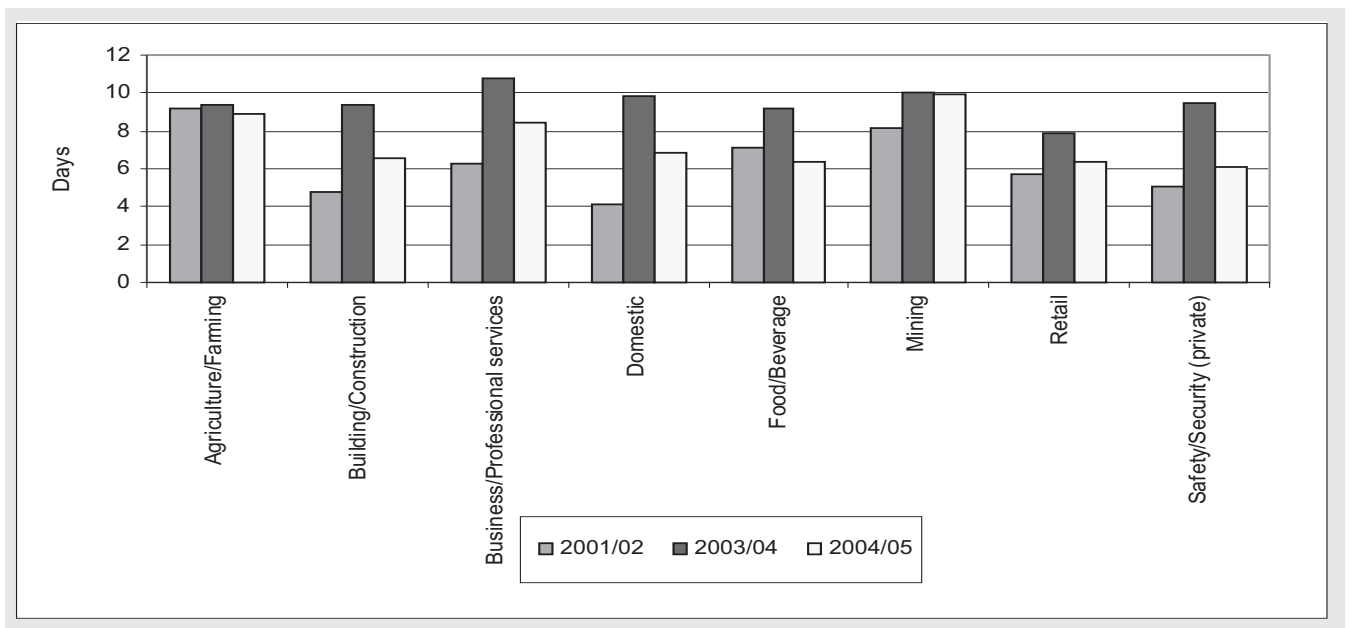

16 Please note that region GAPT has been excluded from the graph. When included, the unusual high turnaround time in $2004 / 05$ led to biased view on all the other regions. 


\section{Conciliation: Average Number of Days between Activation and End Date}

Table 19: Conciliation: Average Turnaround Times (Activation to End)

\begin{tabular}{|l|r|r|r|}
\hline & $\mathbf{2 0 0 1 / 0 2}$ & $\mathbf{2 0 0 3 / 0 4}$ & $\mathbf{2 0 0 4 / 0 5}$ \\
\hline By region: & & & \\
ECEL & 37.9 & 37.7 & 33.9 \\
ECPE & 42.7 & 37.5 & 40.3 \\
FS & 40.5 & 27.4 & 30.5 \\
GAJB & 55.3 & 58.0 & 60.0 \\
GAPT & -- & 141.8 & 50.7 \\
KNDB & 31.5 & 28.5 & 32.0 \\
KNPM & 44.4 & 26.5 & 31.1 \\
KNRB & 42.0 & 31.9 & 30.7 \\
LP & 35.8 & 40.8 & 41.9 \\
MP & 37.2 & 41.8 & 55.0 \\
NC & 28.1 & 28.3 & 32.0 \\
NW & 41.2 & 39.4 & 35.0 \\
WE & 37.7 & 34.6 & 34.4 \\
By main sector: & & & \\
Agriculture/Farming & 43.1 & 43.5 & 45.1 \\
Building/Construction & 42.4 & 46.5 & 46.5 \\
Business/Professional services & 43.3 & 49.6 & 42.9 \\
Domestic & 48.4 & 46.6 & 51.0 \\
Food/Beverage & 41.5 & 41.0 & 40.6 \\
Mining & 44.5 & 44.9 & 45.0 \\
Retail & 39.8 & 40.6 & 40.8 \\
Safety/Security (private) & 47.2 & 46.1 & 48.0 \\
National average & 44.2 & 44.0 \\
\hline
\end{tabular}

Table 19 indicates that there are significant regional variations in the average turn around times with the largest office (Johannesburg) having consistently the longest request turnaround. The range of sectoral varieties is considerably narrower.

The national average for conciliations that are successfully resolved has been remarkably consistent. 
Figure 21: Conciliation: Average Turnaround Times (Activation to End) by Region

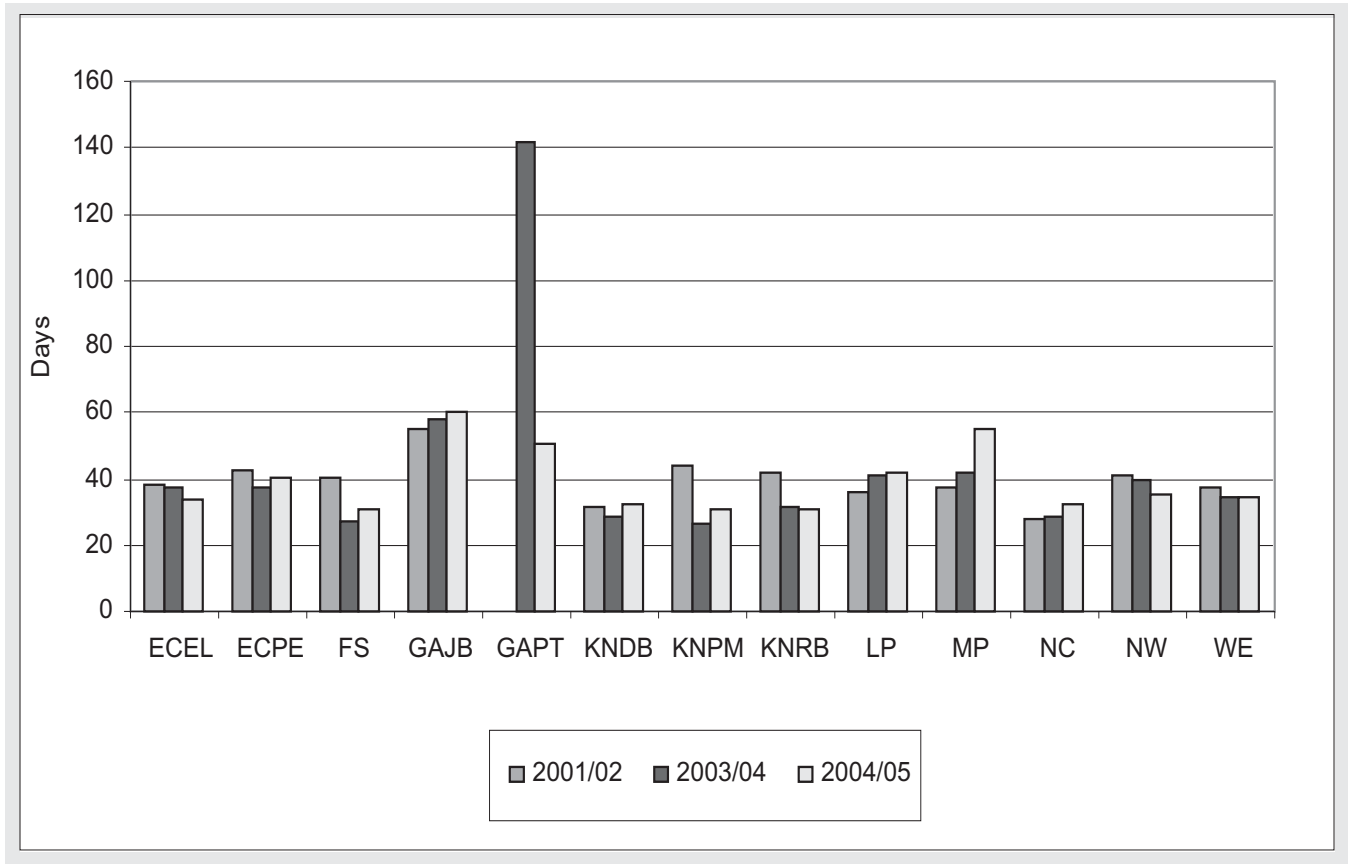

Figure 22: Conciliation: Average Turnaround Times (Activation to End) by Main Sector

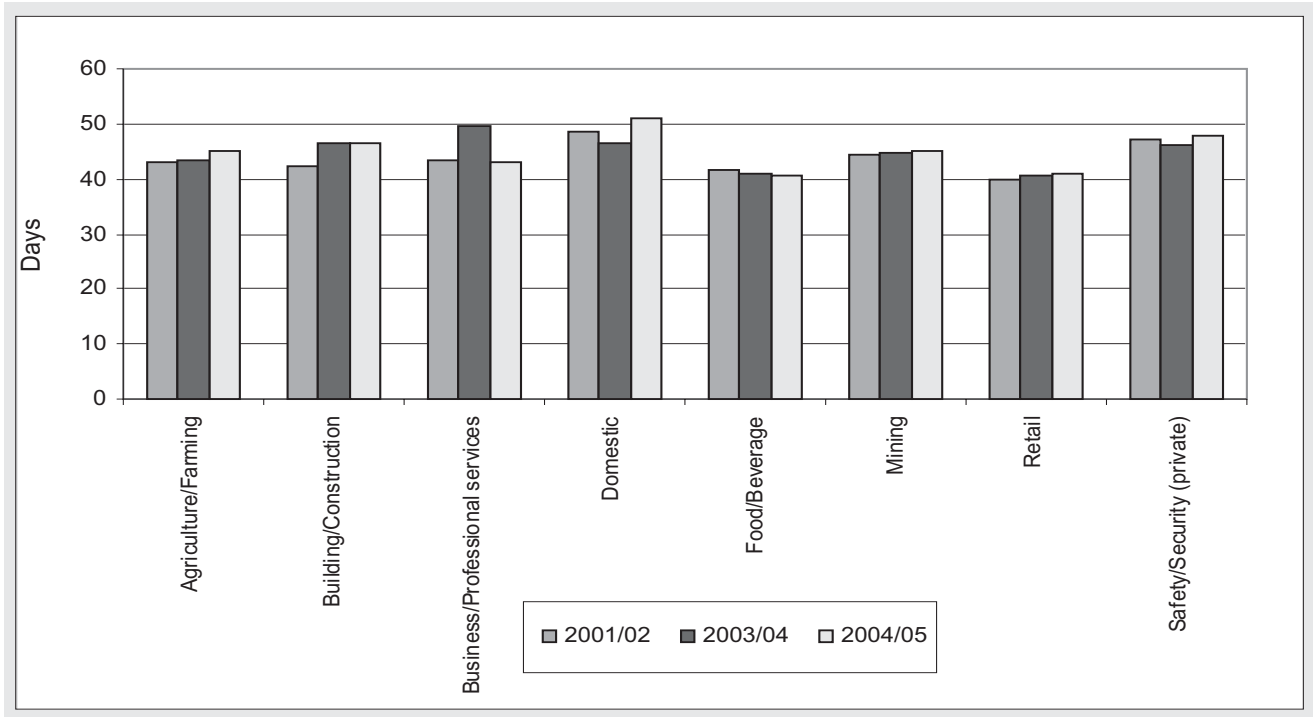




\section{Arbitration: Average Number of Days between Referral and Activation} Date

Table 20: Arbitration: Average Turnaround Times (Referral to Activation)

\begin{tabular}{|c|c|c|c|}
\hline & $2001 / 02$ & $2003 / 04$ & $2004 / 05$ \\
\hline \multicolumn{4}{|l|}{ By region: } \\
\hline ECEL & 12.1 & 16.9 & 14.7 \\
\hline ECPE & 7.1 & 2.2 & 7.8 \\
\hline FS & 8.5 & 10.4 & 11.5 \\
\hline GAJB & 6.8 & 14.9 & 7.8 \\
\hline GAPT & -- & 57.5 & 5.3 \\
\hline KNDB & 3.5 & 1.1 & 1.4 \\
\hline KNPM & 6.7 & 0.5 & 1.7 \\
\hline KNRB & 3.1 & 1.9 & 3.4 \\
\hline LP & 6.3 & 10.5 & 5.6 \\
\hline MP & 17.7 & 8.9 & 6.7 \\
\hline NC & 8.5 & 7.9 & 10.4 \\
\hline NW & 10.5 & 11.9 & 14.7 \\
\hline WE & 10.9 & 10.6 & 7.5 \\
\hline \multicolumn{4}{|l|}{ By main sector: } \\
\hline Agriculture/Farming & 8.6 & 12.5 & 8.9 \\
\hline Building/Construction & 5.9 & 11.0 & 6.7 \\
\hline Business/Professional services & 6.4 & 14.3 & 7.7 \\
\hline Domestic & 3.8 & 9.1 & 6.0 \\
\hline Food/Beverage & 8.3 & 9.0 & 6.2 \\
\hline Mining & 11.0 & 9.5 & 11.1 \\
\hline Retail & 7.0 & 9.4 & 6.2 \\
\hline Safety/Security (private) & 6.7 & 9.6 & 5.6 \\
\hline National average & 7.8 & 10.6 & 7.1 \\
\hline
\end{tabular}


Figure 23: Arbitration: Average Turnaround (Referral to Activation) Times by Region

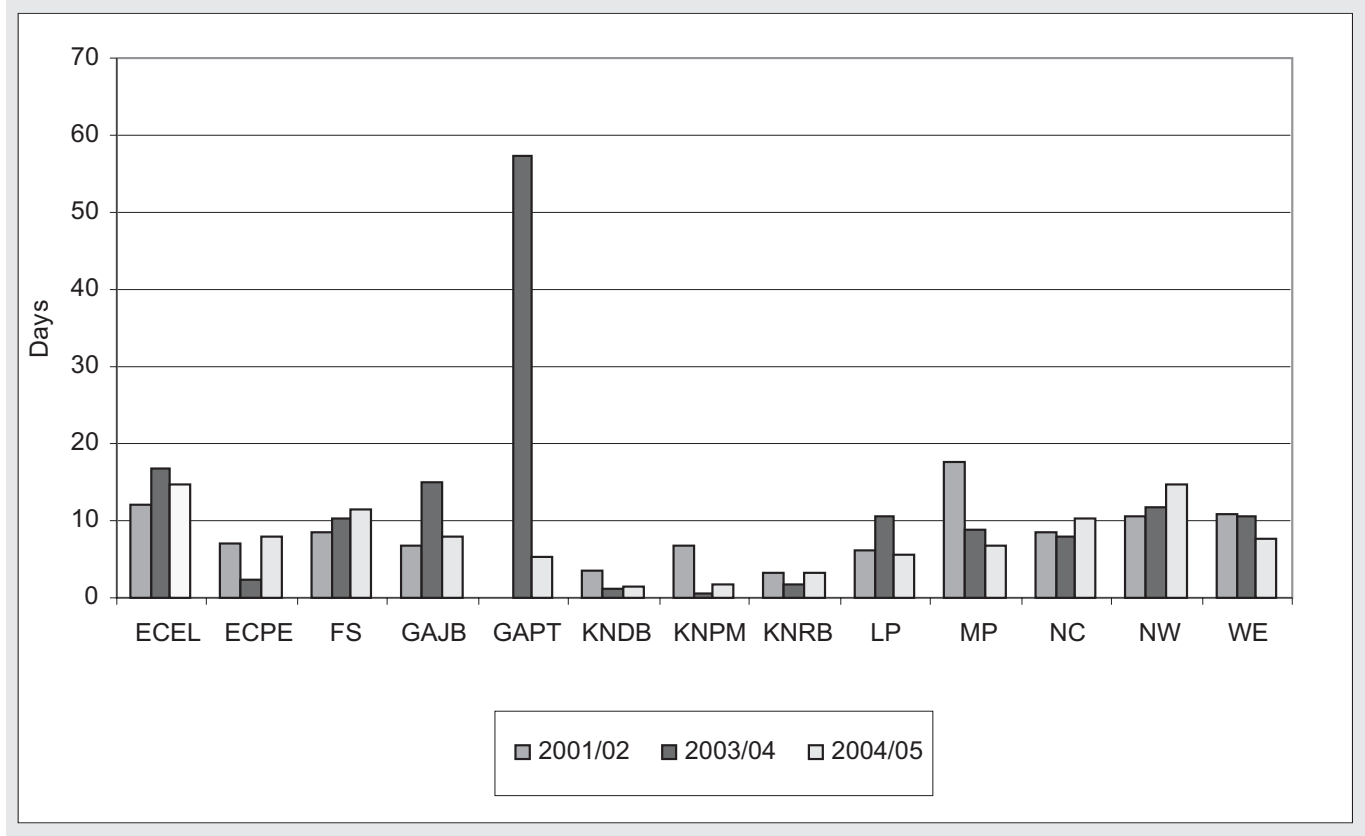

Figure 24: Arbitration: Average Turnaround Times (Referral to Activation) by Main Sector

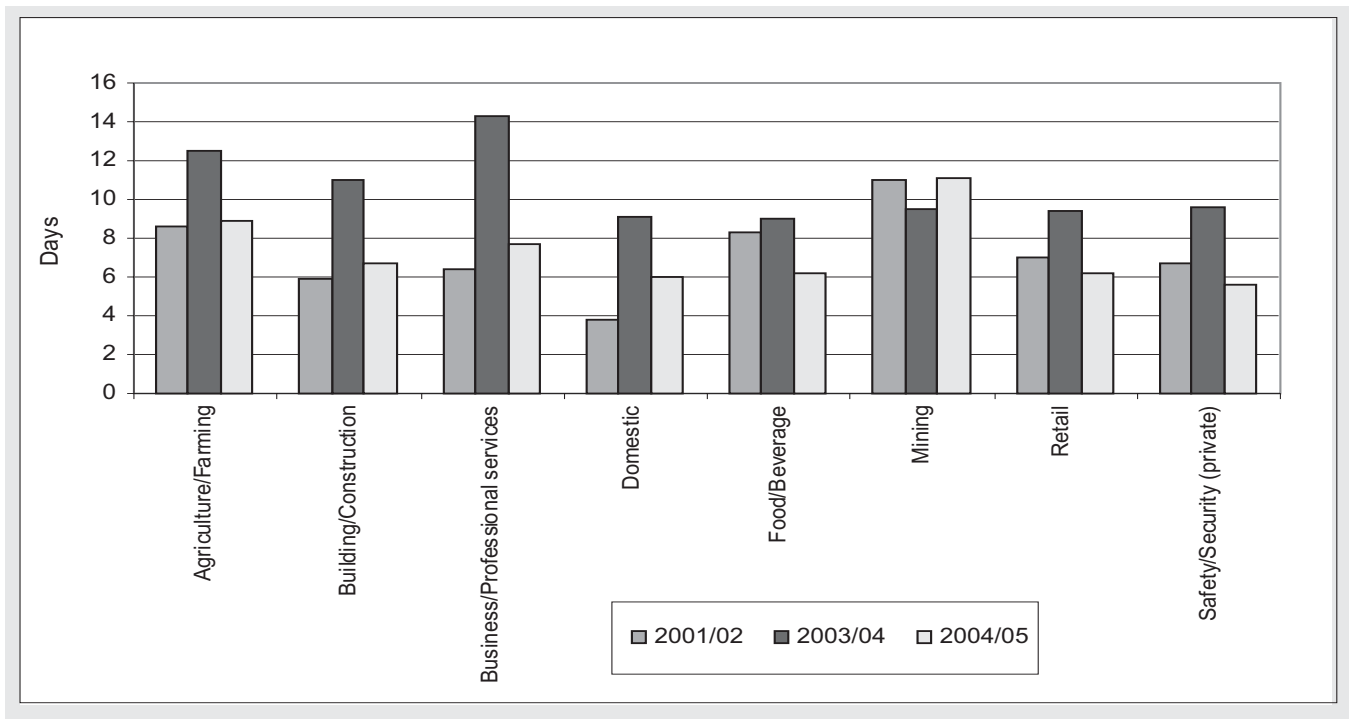




\section{Arbitration: Average Number of Days between Activation and Arbitration Request Date}

Table 21: Arbitration: Average Turnaround Times (Activation to Arbitration Request)

\begin{tabular}{|l|r|r|r|}
\hline & $\mathbf{2 0 0 1 / 0 2}$ & $\mathbf{2 0 0 3 / 0 4}$ & $\mathbf{2 0 0 4 / 0 5}$ \\
\hline By region: & & & \\
ECEL & 126.8 & 179.2 & 81.8 \\
ECPE & 99.8 & 83.5 & 74.1 \\
FS & 93.1 & 69.0 & 76.9 \\
GAJB & 163.6 & 96.7 & 100.0 \\
GAPT & -- & 216.1 & 64.6 \\
KNDB & 82.4 & 58.7 & 56.8 \\
KNPM & 95.5 & 86.6 & 62.6 \\
KNRB & 81.2 & 43.0 & 57.0 \\
LP & 112.0 & 97.4 & 86.0 \\
MP & 110.4 & 61.5 & 61.8 \\
NC & 67.0 & 56.9 & 54.2 \\
NWW & 101.5 & 68.3 & 68.2 \\
WE & 86.1 & 59.8 & 59.5 \\
By main sector: & & & \\
Agriculture/Farming & 103.9 & 84.9 & 79.7 \\
Building/Construction & 125.4 & 88.4 & 87.4 \\
Business/Professional services & 134.9 & 93.8 & 82.1 \\
Domestic & 125.8 & 85.7 & 89.3 \\
Food/Beverage & 120.0 & 85.3 & 71.8 \\
Mining & 144.3 & 83.8 & 82.4 \\
Retail & 124.5 & 81.4 & 76.0 \\
Safety/Security (private) & 134.2 & 84.7 & 79.6 \\
\hline National average & 130.0 & 86.4 & 81.2 \\
\hline
\end{tabular}

Section 136(1)(b) provides that an employee who wishes to refer a dispute to arbitration must do so within 90 days of the conclusion of the conciliation phase. A comparison between Tables 19 and 21 show that in 2003/4 and 2004/5 on average the period between the referral is made on average approximately 40 days after the end of the conciliation phase. It also shows that the time period for making the request has dropped from approximately 86 in 2001-2002. 
Figure 25: Arbitration: Average Turnaround (Activation to Arbitration Request) Times by Region

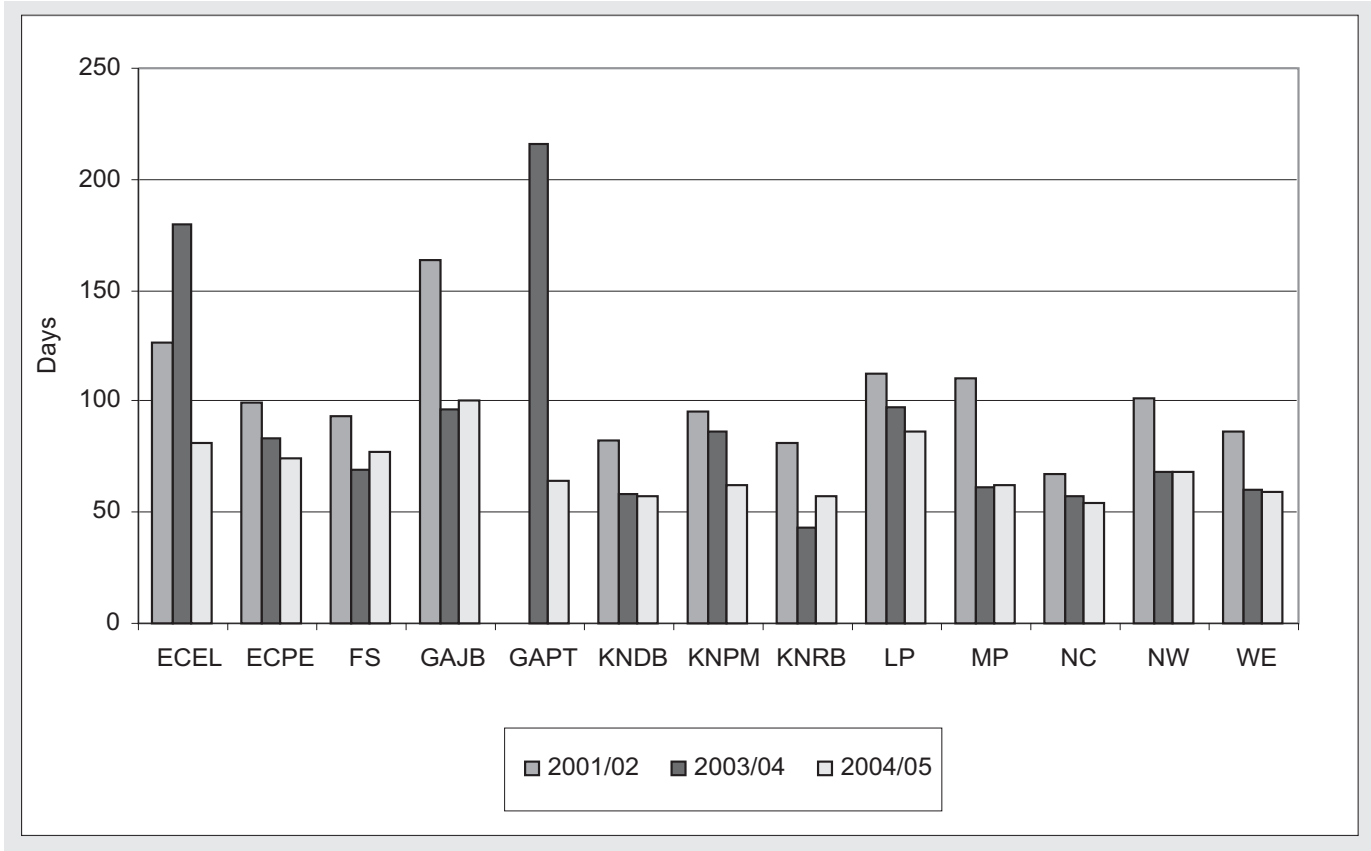

Figure 26: Arbitration: Average Turnaround Times (Activation to Arbitration Request) by Main Sector

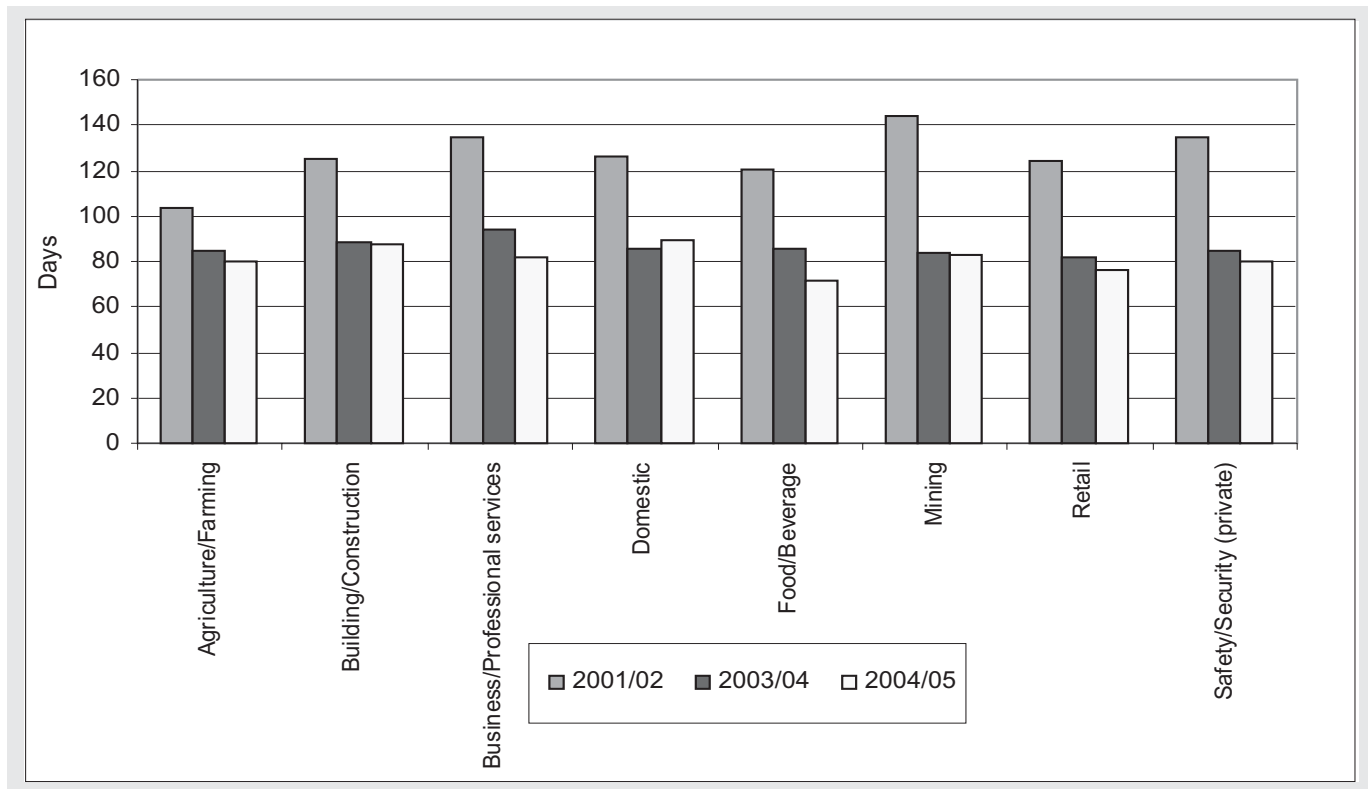


Arbitration: Average Number of Days between Arbitration Request and Award Date

Table 22: Arbitration: Average Turnaround Times (Arbitration Request to Award)

\begin{tabular}{|l|r|r|r|}
\hline & $\mathbf{2 0 0 1 / 0 2}$ & $\mathbf{2 0 0 3 / 0 4}$ & $\mathbf{2 0 0 4 / 0 5}$ \\
\hline By region: & & & \\
ECEL & 228.2 & 209.4 & 156.5 \\
ECPE & 177.0 & 161.0 & 117.8 \\
FS & 204.6 & 237.1 & 166.0 \\
GAJB & 206.9 & 175.3 & 125.1 \\
GAPT & -- & 94.4 & 88.8 \\
KNDB & 122.2 & 132.9 & 114.5 \\
KNPM & 134.6 & 304.1 & 120.3 \\
KNRB & 114.0 & 92.8 & 101.6 \\
LP & 141.5 & 142.7 & 119.1 \\
MP & 139.1 & 147.2 & 103.9 \\
NC & 77.2 & 81.0 & 88.8 \\
NW & 115.3 & 115.9 & 114.8 \\
WE & 150.0 & 180.5 & 138.3 \\
By main sector: & 179.0 & 174.3 & 126.2 \\
Agriculture/Farming & 1767.6 & 171.6 & 133.5 \\
Building/Construction & 192.0 & 190.1 & 131.2 \\
Business/Professional services & 168.3 & 177.2 & 121.6 \\
Domestic & 176.3 & 181.7 & 132.7 \\
Food/Beverage & 182.0 & 168.8 & 125.8 \\
Mining & 156.4 & 118.6 \\
Retail & 163.8 & 117.4 \\
Safety/Security (private) & & & \\
\hline National average & 112.0 \\
\hline
\end{tabular}


The average turn around times for arbitrations as measured between the arbitration request (referral) and the award have decreased very significantly (by 48 days) between $2003 / 4$ and 2004/5.

Figure 27: Arbitration: Average Turnaround (Arbitration Request to Award) Times by Region

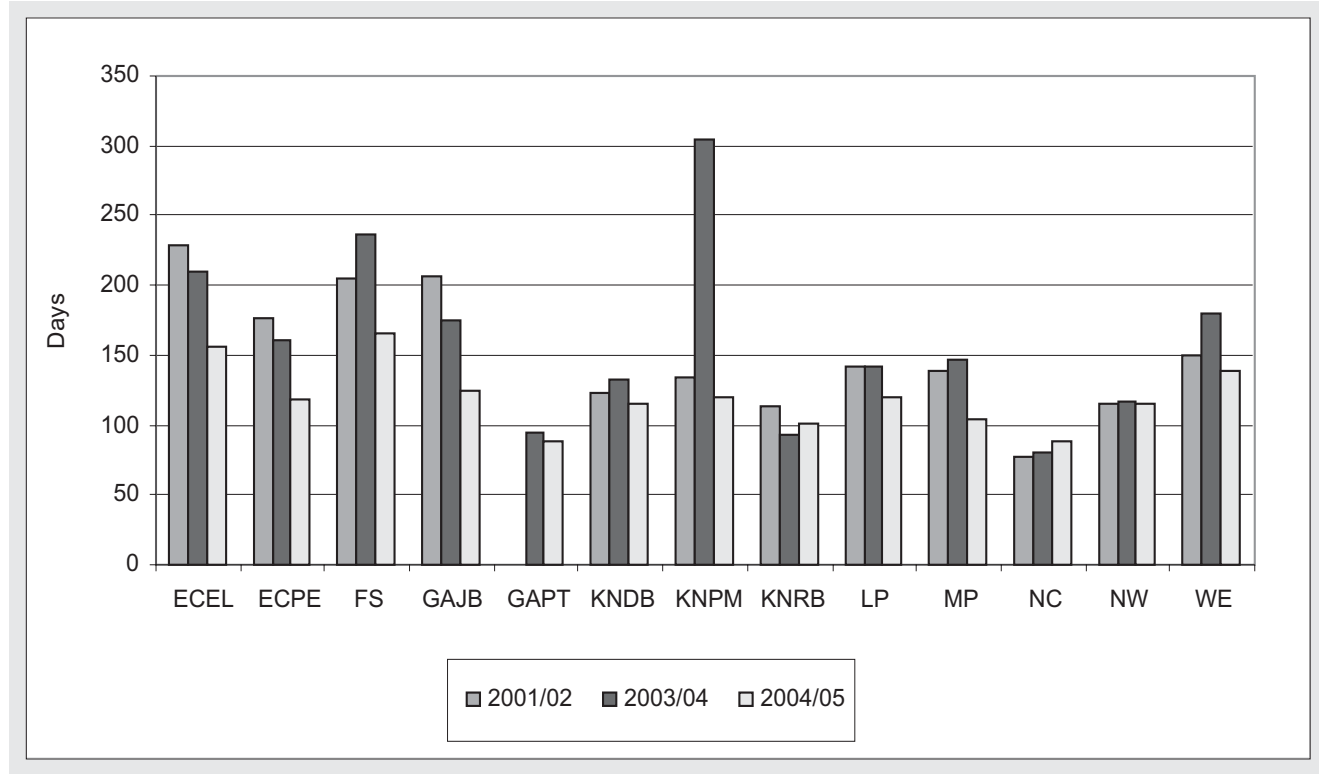

Figure 28: Arbitration: Average Turnaround Times (Arbitration Request to Award) by Main Sector

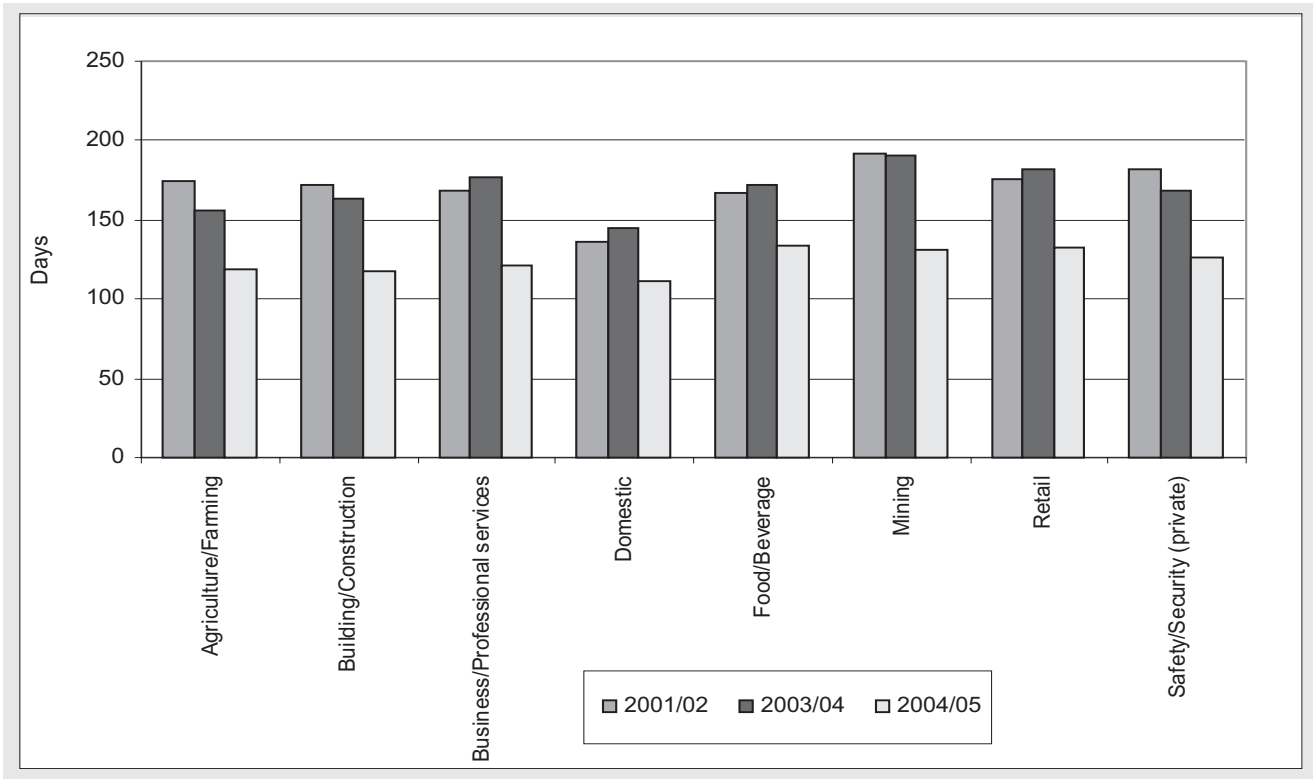




\section{Arbitration: Average Number of Days between Activation and End Date}

Table 23: Arbitration: Average Turnaround Times (Activation to End)

\begin{tabular}{|l|r|r|r|}
\hline & $\mathbf{2 0 0 1 / 0 2}$ & $\mathbf{2 0 0 3 / 0 4}$ & $\mathbf{2 0 0 4 / 0 5}$ \\
\hline By region: & & & \\
ECEL & 222.4 & 362.0 & 219.1 \\
ECPE & 192.2 & 204.4 & 189.0 \\
FS & 236.7 & 277.1 & 226.5 \\
GAJB & 271.4 & 243.7 & 208.8 \\
GAPT & -- & 507.9 & 137.5 \\
KNDB & 132.0 & 125.4 & 140.8 \\
KNPM & 215.4 & 108.1 & 171.9 \\
KNRB & 172.8 & 121.2 & 144.3 \\
LP & 159.3 & 223.8 & 213.9 \\
MP & 196.4 & 153.6 & 159.4 \\
NC & 108.3 & 99.9 & 115.0 \\
NW & 152.6 & 131.8 & 163.8 \\
WE & 166.3 & 199.4 & 177.7 \\
By main sector: & & & \\
Agriculture/Farming & 199.4 & 196.9 & 189.2 \\
Building/Construction & 204.3 & 198.1 & 183.8 \\
Business/Professional services & 231.5 & 232.0 & 186.8 \\
Domestic & 188.2 & 182.7 & 183.9 \\
Food/Beverage & 209.4 & 200.5 & 180.5 \\
Mining & 228.7 & 209.9 & 201.0 \\
Retail & 208.4 & 202.7 & 184.6 \\
Safety/Security (private) & 218.5 & 198.2 & 184.3 \\
\hline National average & 212.9 & 206.3 & 187.3 \\
\hline
\end{tabular}

Table 23 measures the time taken for those cases that are determined by arbitration measured from the activation of the matter to the final outcome of the arbitration. Again, there is a significant decrease (19 days) in the period involved between 2003/4 and $2004 / 5$. 
Figure 29: Arbitration: Average Turnaround (Activation to End) Times by Region

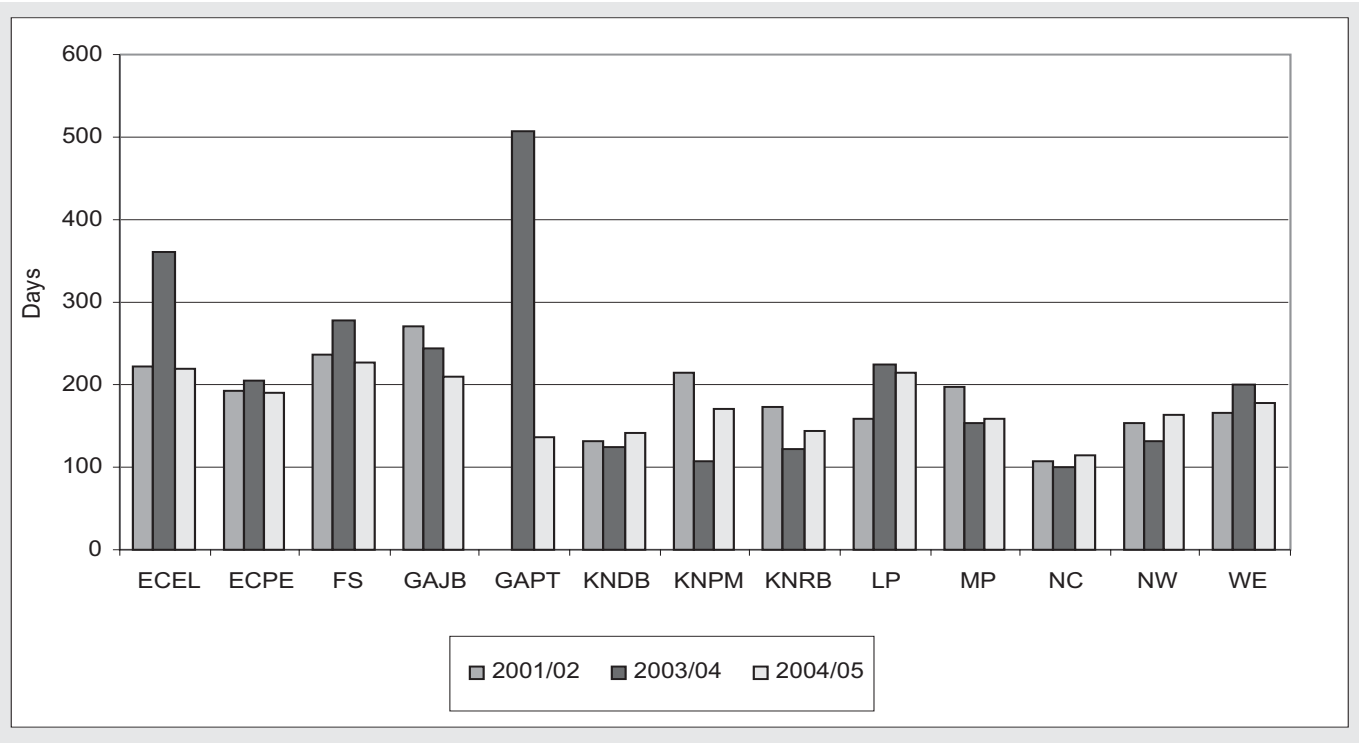

Figure 30: Arbitration: Average Turnaround Times (Activation to End) by Main Sector

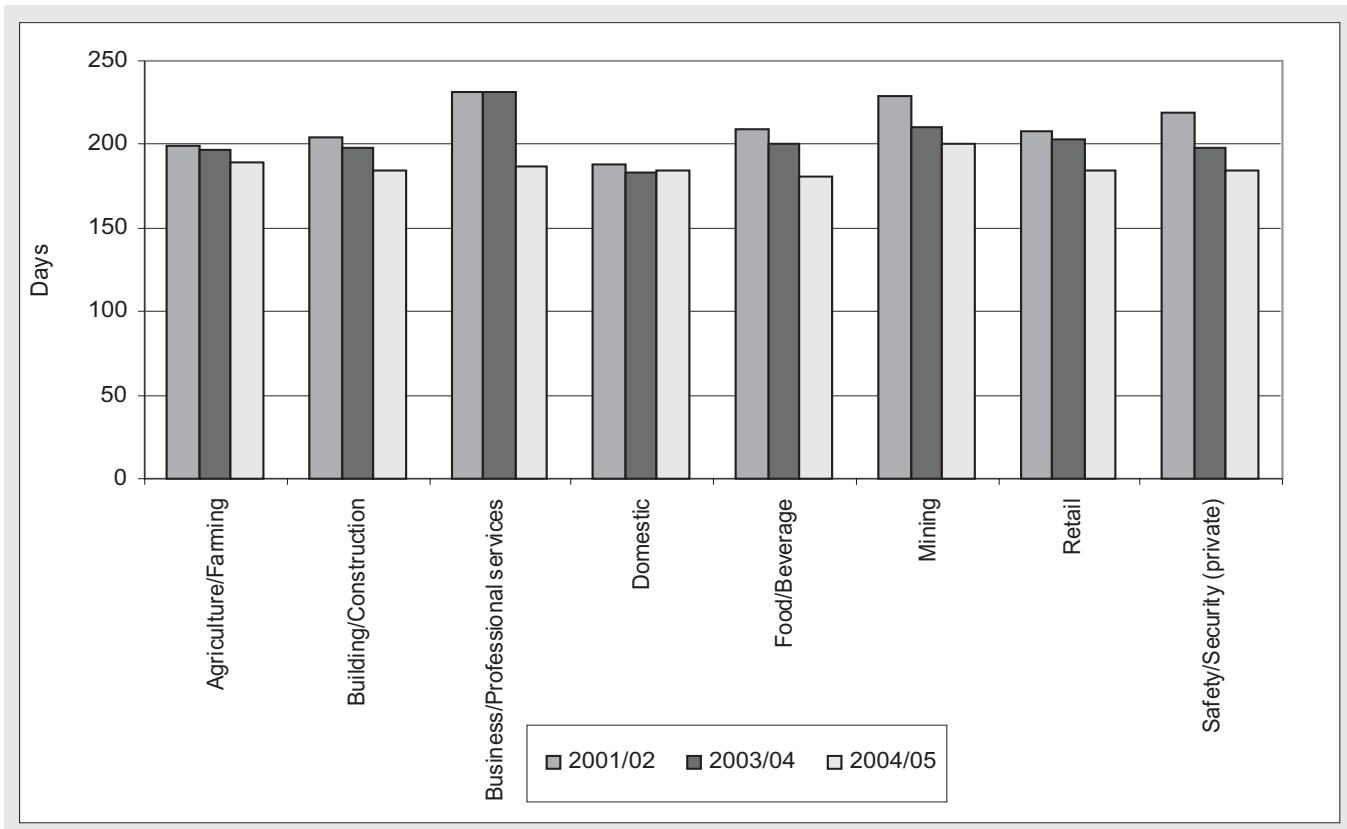




\section{Con/Arb: Average Number of Days between Referral and Activation} Date $^{17}$

Table 24: Con/Arb: Average Turnaround Times (Referral to Activation)

\begin{tabular}{|l|r|r|r|}
\hline & $\mathbf{2 0 0 1 / 0 2}$ & $\mathbf{2 0 0 3 / 0 4}$ & $\mathbf{2 0 0 4 / 0 5}$ \\
\hline By region: & & & \\
ECEL & -- & 10.8 & 9.8 \\
ECPE & -- & 0.9 & 4.7 \\
FS & -- & 7.7 & 10.7 \\
GAJB & 961.0 & 15.4 & 6.5 \\
GAPT & -- & 3.0 & 2.8 \\
KNDB & -- & 0.9 & 0.7 \\
KNPM & -- & 0.7 & 1.2 \\
KNRB & -- & 4.1 & 3.0 \\
LP & -- & 18.3 & 4.3 \\
MP & -- & 7.7 & 4.6 \\
NC & -- & 3.7 & 7.5 \\
NW & -- & 9.6 & 10.0 \\
WE & -- & 17.4 & 4.4 \\
By main sector: & & & \\
Agriculture/Farming & -- & 10.7 & 5.1 \\
Building/Construction & -- & 6.9 & 4.6 \\
Business/Professional services & -- & 11.8 & 5.1 \\
Domestic & -- & 7.3 & 4.8 \\
Food/Beverage & -- & 7.3 & 3.9 \\
Mining & -- & 6.7 & 10.2 \\
Retail & -- & 6.2 & 4.3 \\
Safety/Security (private) & -- & 6.8 & 4.3 \\
\hline National average & 320.3 & 7.7 & 4.9 \\
\hline
\end{tabular}

17 Due to the limited number of observations regarding Con/Arb especially in the early sample years, the figures will only show relevant regions and sectors for 2003/04 and 2004/05. 
Figure 31: Con/Arb: Average Turnaround (Referral to Activation) Times by Region



Figure 32: Con/Arb: Average Turnaround Times (Referral to Activation) by Main Sector




Table 25: Con/Arb: Average Turnaround Times (Arbitration Request to Award)

\begin{tabular}{|l|r|r|r|}
\hline & $2001 / 02$ & $2003 / 04$ & $2004 / 05$ \\
\hline By region: & -- & & \\
ECEL & -- & - & -- \\
ECPE & -- & - & 17.0 \\
FS & -- & 8.5 & 8.0 \\
GAJB & -- & -- & -- \\
GAPT & -- & -- & -- \\
KNDB & -- & -- & - \\
KNPM & -- & - & - \\
KNRB & -- & - & - \\
LP & -- & 52.3 & 280.0 \\
MP & -- & -- & -- \\
NC & -- & 2.0 & -- \\
NW & -- & -- & -- \\
WE & & & \\
By main sector: & -- & -- & -- \\
Agriculture/Farming & -- & 2.0 & -- \\
Building/Construction & -- & 2.0 & -- \\
Business/Professional services & -- & - \\
Domestic & - & - \\
Food/Beverage & -- & 48.0 & 8.0 \\
Mining & -- & -- \\
Retail & -- & 61.0 & 17.0 \\
Safety/Security (private) & -- & -- \\
\hline National average & -- & 86.5 \\
\hline
\end{tabular}

Table 25 shows that the average turnaround time for con-arb is approximately 30 days. This compares very favourably with the time period for conciliations and arbitrations. These figures appear to include matters referred to con-arb where there is no objection to the arbitration phase, commencing immediately after the conciliation is completed. In contrast, Tables 26 reflect a much larger turn around times for cases in which a party objects to con-arb and there is then a separate referral to arbitration. 
Figure 33: Con/Arb: Average Turnaround (Activation to End) Times by Region

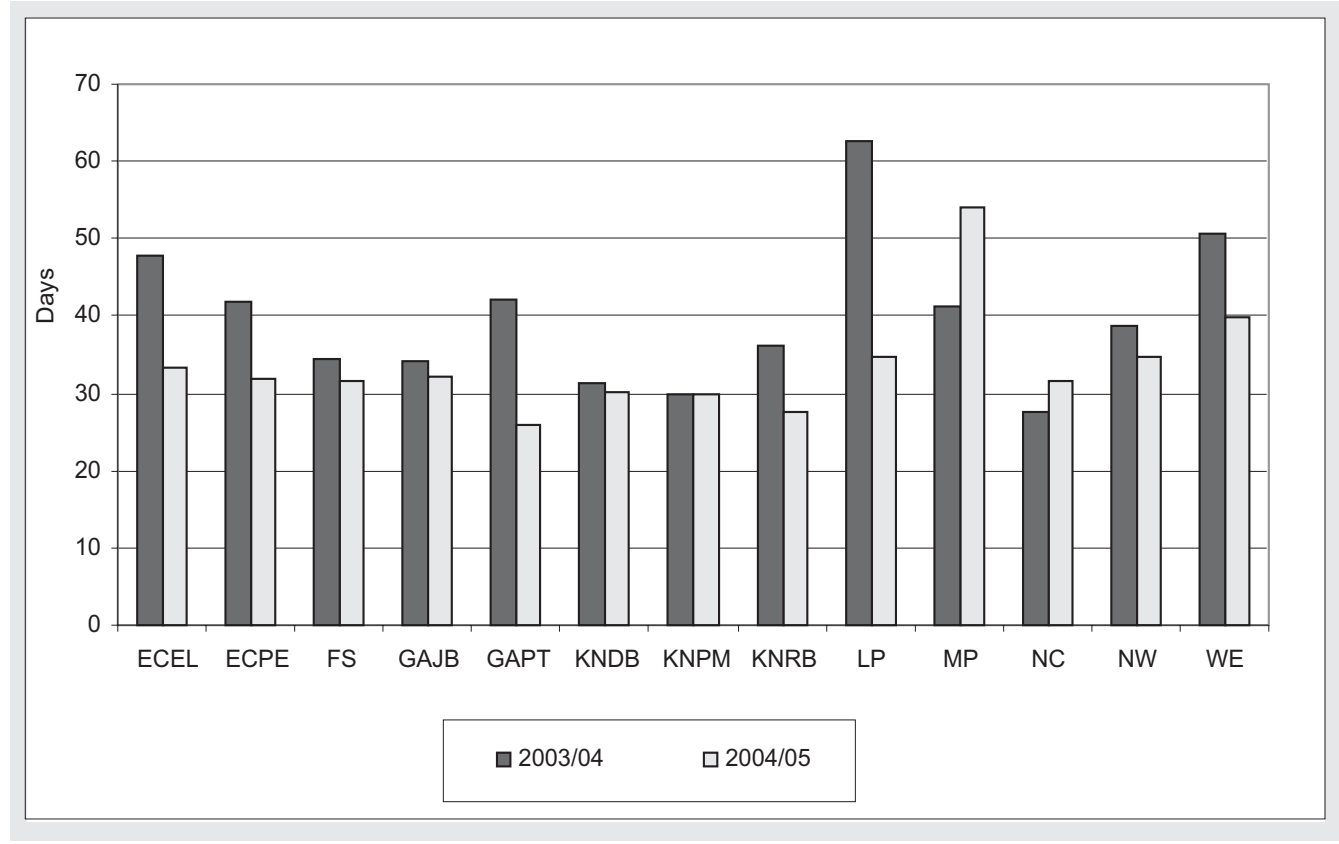

Figure 34: Con/Arb: Average Turnaround Times (Activation to End) by Main Sector




Figure 35: Con/Arb: Average Turnaround (Activation to Arbitration Request) Times by Region

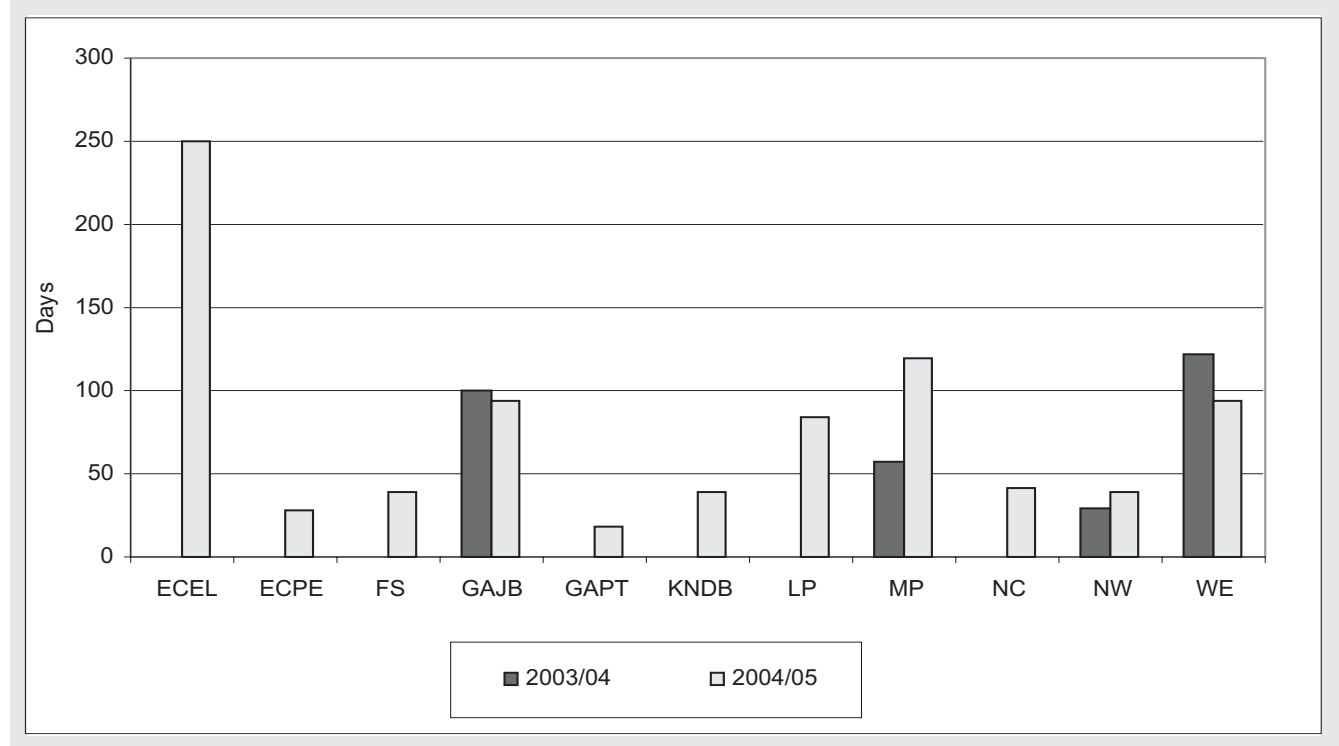

Figure 36: Con/Arb: Average Turnaround Times (Activation to Arbitration Request) by Main Sector

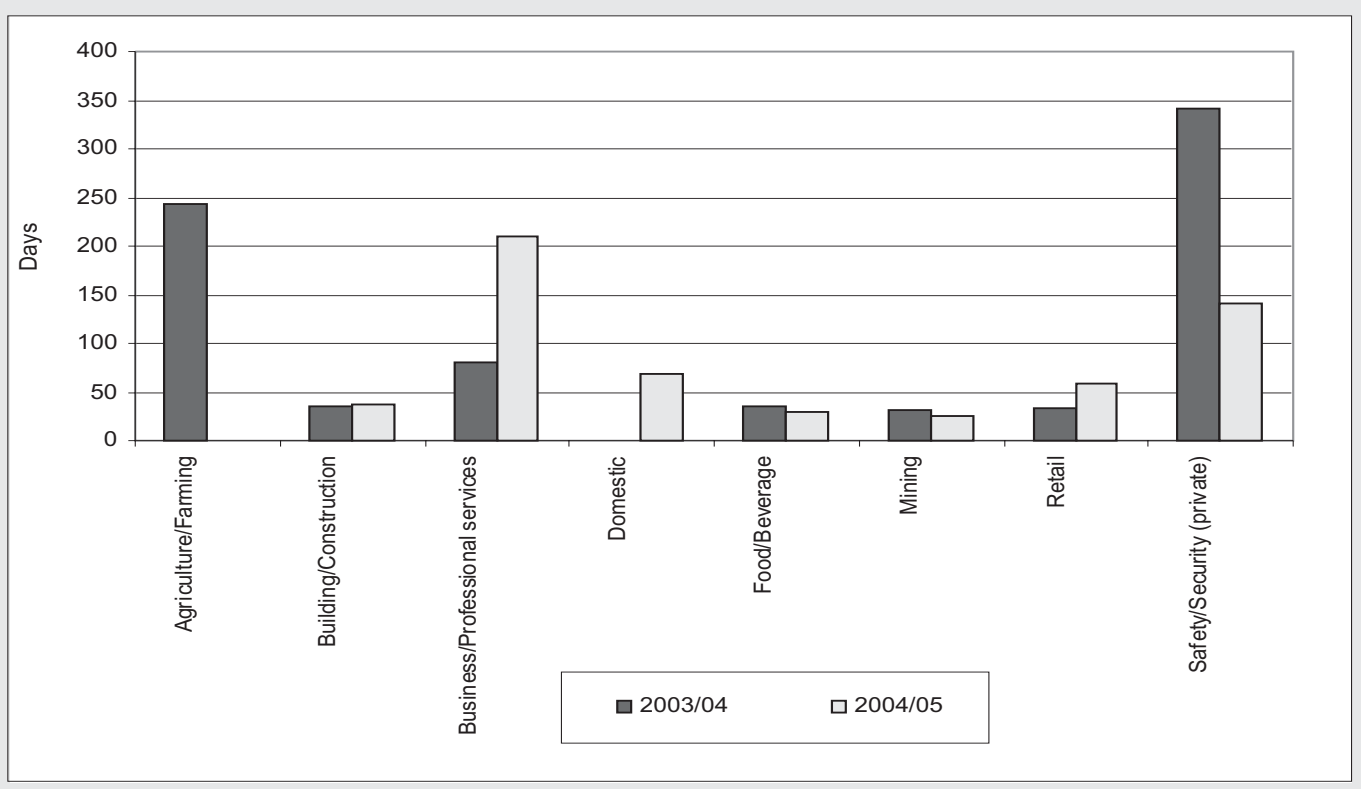


Con/Arb: Average Number of Days between Arbitration Request and Award Date

Table 26: Con/Arb: Average Turnaround Times (Activation to End)

\begin{tabular}{|l|r|r|r|}
\hline & $2001 / 02$ & $2003 / 04$ & $2004 / 05$ \\
\hline By region: & & & \\
ECEL & -- & 47.8 & 33.3 \\
ECPE & -- & 41.8 & 31.8 \\
FS & -- & 34.3 & 31.6 \\
GAJB & 29.0 & 34.2 & 32.2 \\
GAPT & -- & 42.0 & 26.0 \\
KNDB & -- & 31.4 & 30.2 \\
KNPM & -- & 30.0 & 29.7 \\
KNRB & -- & 36.1 & 27.6 \\
LP & -- & 62.7 & 34.6 \\
MP & 585.0 & 41.4 & 54.0 \\
NC & -- & 27.7 & 31.5 \\
NWW & -- & 38.8 & 34.7 \\
WE & -- & 50.6 & 39.8 \\
By main sector: & & & \\
Agriculture/Farming & -- & 40.5 & 41.8 \\
Building/Construction & -- & 33.8 & 32.7 \\
Business/Professional services & -- & 36.3 & 32.9 \\
Domestic & -- & 34.6 & 32.5 \\
Food/Beverage & -- & 35.3 & 33.5 \\
Mining & -- & 39.1 & 36.9 \\
Retail & 691.0 & 34.1 & 33.1 \\
Safety/Security (private) & -- & 33.7 & 32.0 \\
\hline National average & 399.7 & 34.7 & 33.5 \\
\hline
\end{tabular}


Figure 37: Con/Arb: Average Turnaround (Arbitration Request to Award) Times by Region

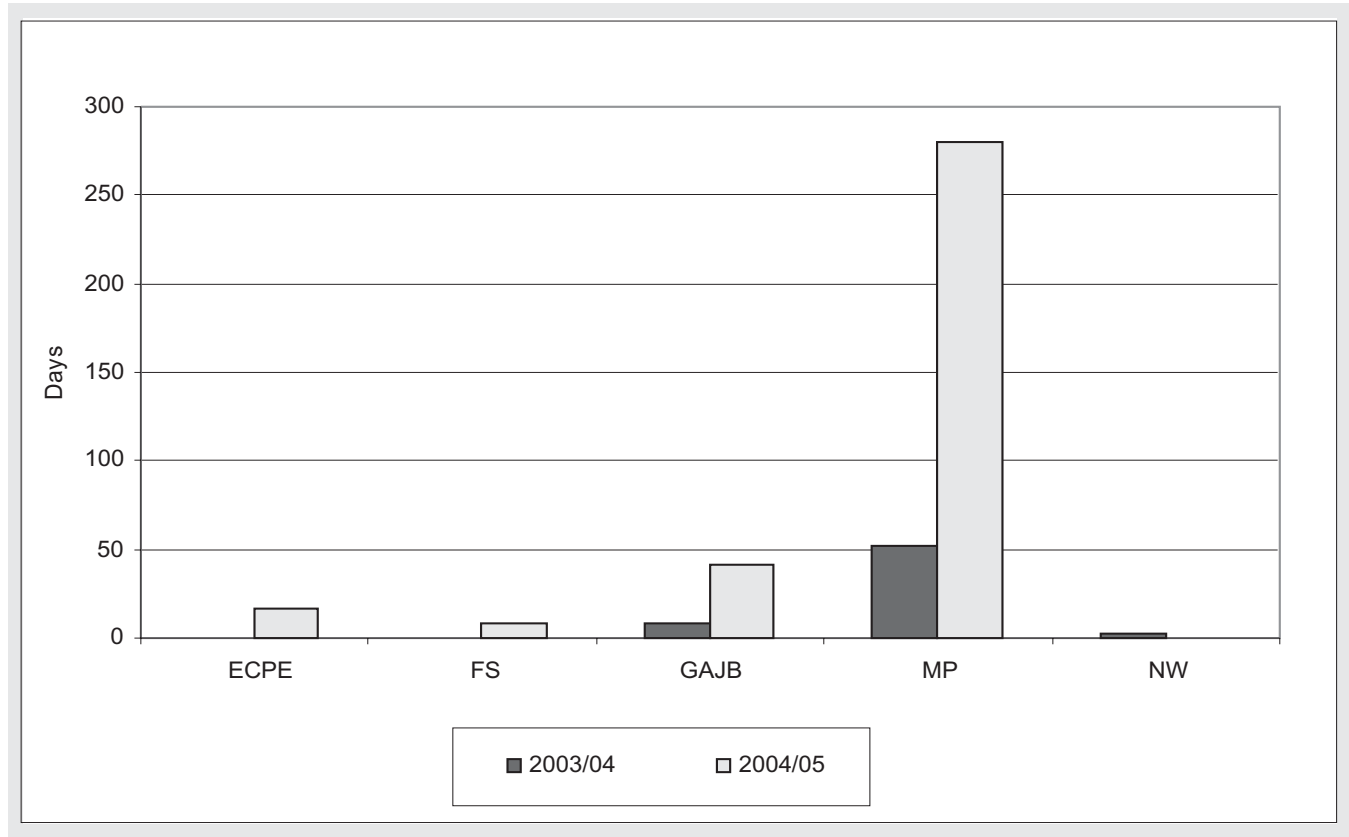

Figure 38: Con/Arb: Average Turnaround Times (Arbitration Request to Award) by Main Sector

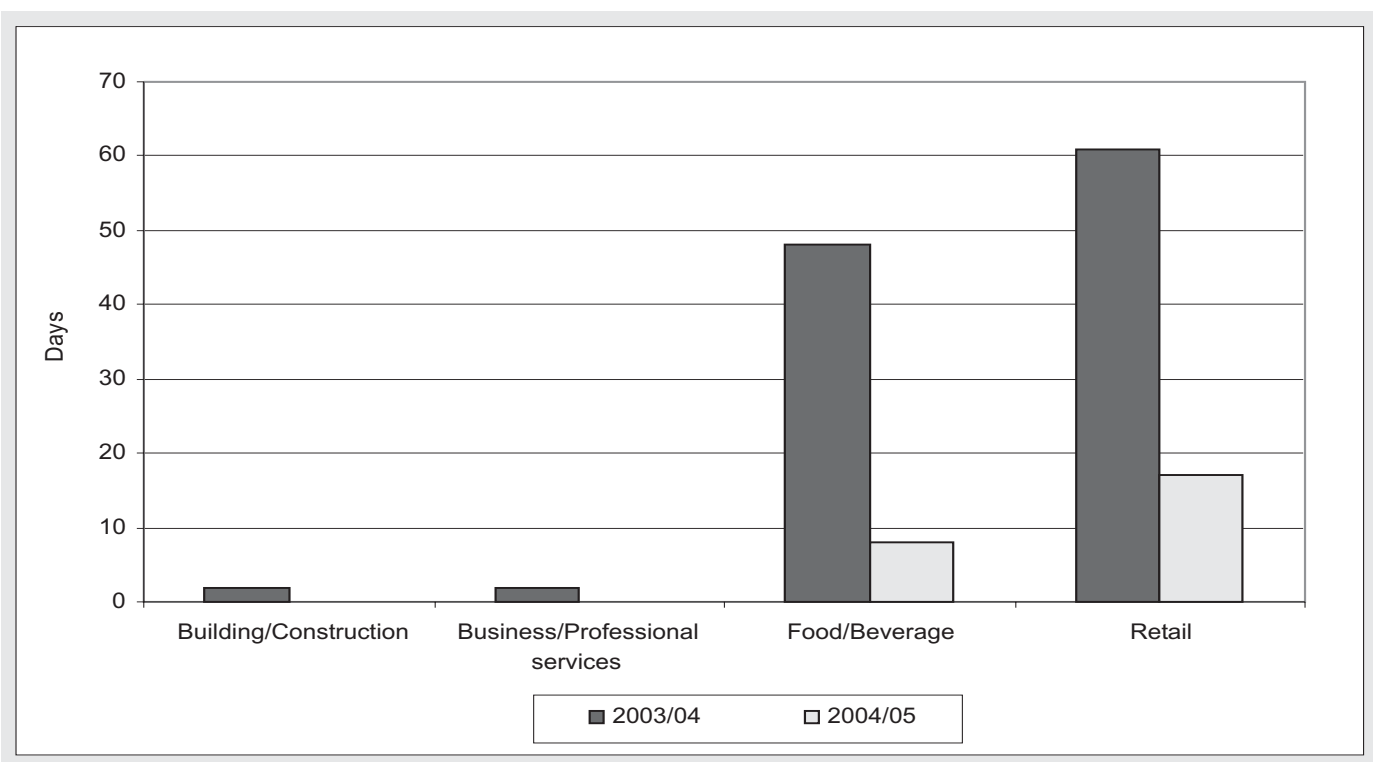




\section{Data not Reflected in CMS}

\section{Employee's Length of Service}

The CMS does not contain any information concerning the length of service of employees who refer disputes to the CCMA. While an employee's length of service may not be of immediate relevance for the administrative purposes of the CMS, it is an issue that is important for assessing the impact of protection against unfair dismissal on the economy.

There is a broadly held perception that a substantial proportion of dismissal cases referred to the CCMA concern employees with an extremely short length of service. This factor is seen as having a particularly severe 'chilling' effect on decisions by employers to employ additional employees.

Presently, the Unfair Dismissal Code of Practice LRA regulates the issue by allowing arbitrators to accept "less compelling" reasons to establish the fairness of dismissals during an initial probationary period of "reasonable duration". While this does create a certain relaxation of standards during probation, it does not provide clear guidance either as to standards or the period in which these are applicable.

The issue of the regulation of probation enjoyed significant attention during the negotiation of the 2002 LRA Amendment Act. The Explanatory Memorandum to the 2000 LRA Amendment Bill argued that arbitrators and judges give insufficient recognition to the provisions for a probationary period in the Act and Code. The proposed changes to the Act to set a six-month probationary period and clarify the applicable rules were not included in the Amendment Act. ${ }^{18}$

Internationally, it is common for countries to have a threshold period during which employees do not have protection against dismissal except for egregious reasons such as discrimination or trade union victimisation. This is the case in the UK during the first year of employment.

It would not be unduly onerous for the CCMA to obtain information concerning the length of service of applicants in dismissal cases either as part of the CMS or as part of special research project.

18 For an academic commentary see Cohen (2003). 


\section{Earnings Level of Applicants}

The CMS does not require the recording of information concerning the earnings level of employees who refer cases to the CCMA. Again, this information is not relevant for the administrative purposes of the CMS. However, knowledge of the income categories from which applicants are drawn would assist to assess the economic impact of the CCMA. It is often argued that the criticism of the CCMA advanced by employers is based on anecdotal evidence concerning cases brought by middle and high-income employees rather than semi-skilled and unskilled workers.

An amendment to allow the CCMA to charge arbitration fees to parties involved in disputes concerning employers earning in excess of a defined earnings threshold was proposed in the 2000 LRA Amendment Bill. The justification for this proposal was that the clause would encourage the referral of disputes concerning executives, managers and other highly paid employees to private arbitration. However the clause did not gain the support of the social partners.

As with the issue of length of service, it would not seem unduly onerous for the CCMA to obtain information concerning either the income level or job category of applicants in dismissal cases either as part of the CMS or as part of special research projects.

\section{Size of Employer}

The CMS does not contain information concerning the size of employers. As indicated, reason for this is that the majority of information introduced into this system is obtained from the employee at the time of instituting a dispute.

There has been no detailed study of the impact of CCMA awards on businesses classified as SMMEs. However, the case-study by Theron \& Godfrey concluded that the imposition of compensation awards on smaller businesses had a disproportionate effect.

Again, it would not seem unduly onerous for the CCMA to obtain information concerning size of employer in dismissal cases either as part of the CMS or as part of special research project. 


\section{Representation at the CCMA Arbitrations}

The question of representation of parties at the CCMA involves a number of distinct issues. These are:

a) whether lawyers should have an unfettered right to appear in arbitrations at the CCMA;

b) whether the right of trade unions and employers organisations to appear in proceedings at the CCMA are subject to abuse by "consultant" organisations;

c) whether the activities of labour consultants should be regulated.

The study sought to interrogate data on representation as proceedings before the CCMA. However, the information obtained was not reliable as representation of parties is a nonmandatory field in the CMS. In view of the significance attached to this issue, it is desirable that this information should be recorded more effectively in the future.

\section{Legal Representation}

The right to lawyers to appear in arbitrations has attracted a considerable literature (Benjamin 1994, Buirski 1995, Smythe 2003, Collier 2003, Collier 2005). In essence, a lawyer may only represent a party in an unfair dismissal arbitration if the other party in the case consents or the Commissioner makes a ruling permitting legal representation in the light of the nature of the questions of law raised by the dispute, its complexity, the public interest and the comparative ability of the opposing parties or their representatives to deal with the arbitration. The restriction on legal representation in the CCMA, has been the subject of a constitutional challenge. However, to date these arguments have not succeeded in the Labour Court. ${ }^{19}$

Collier (2005) records the results of a survey among CCMA commissioners, trade unions, employees, employers, legal practitioners and academics on attitudes to legal representation at disciplinary enquiries and CCMA conciliation and arbitration conducted. Of those surveyed, 46 per cent indicated support for retaining the status quo in respect of

19 See Netherburn Engineering CC t/a Netherburn Ceramics v Mudau \& Others (2003) 23 ILJ 1712; Norman Tsie Taxis v Pooe NO \& Others (2004) 25 ILJ 724 (LC) and (2005) 26 ILJ 110 (LC). 
legal representation at arbitrations; 41 per cent believed that legal representation should be allowed at all arbitrations and 12 per cent believed that legal representation should not be allowed at any representation.

\section{Trade Unions and Employers' Organisations}

The amendment introduced in the 2002 LRA Amendment Bill confining registration to "genuine trade unions and employers organisations and providing for guidelines for the registration or de-registration of trade unions and employers organisations" has lead to a significant decrease in the number of registered trade unions in particular due to deregistration. However, it is not known to what extent trade unions and employers that are in fact no more than consultancies operating under the guise of trade unions or employer's organisation continue to operate and appear at the CCMA.

Accurate information concerning patterns of representation would give an important indication as to the cost of disputes for employers as the engaging of lawyers or other advisors represent a significant cost factor. ${ }^{20}$ It may also give significant information as to the reasons for particular patterns in proceedings at the CCMA.

20 As these are tax-deductible expenses, a proportion of that cost is borne by the state through reduced taxation. 


\section{Conclusion}

In order to understand the impact of legislation it is necessary to examine the "legislative, administrative and judicial actions which interact with regulated institutions, beneficiary organisations and individuals to achieve a real world response to a legislative standard". (Blumrosen)

This study has sought to focus on statistical indicators bearing on the administrative efficiency of the CCMA as well as the outcome of proceedings as a basis for assessing its regulatory efficiency.

One of the conclusions of this report is that there are marked differences in the patterns of dispute resolution and the outcome of disputes in different regions. This is particularly true of the implementation of con-arb systems as well in respect of the balance of awards in favour of employers and employees respectively. A closer scrutiny of these differences linked to an understanding of regional difference in institutional cultures and practices could contribute to an improved understanding of the successes and failures of the CCMA.

It was envisaged that the CCMA would provide "simple, non-legalistic and non-jurisdictional procedures" for dispute resolution. As Judge Pillay has pointed out, this is not an accurate description of the CCMA's current operation. Indicative of this is the rising level of in limine and rescission applications and the high level (although not fully documented) of review applications.

The review judgments of the Labour Courts constitute the body of law that must be complied with by the CCMA and it is essential that a mechanism should be found to revise the Code of Good Practice: Dismissal to reflect changes in the law.

This study sought to ascertain the extent to which an interrogation of the database of the CCMA could produce a greater understanding of the impact of the CCMA on the labour market. This database was designed for purposes of case-management and this orientation is reflected in the information contained in it. While this information gives a picture of the operation of the CCMA, additional information is required to assess the impact of the CCMA on particular categories of employers, to ascertain which categories of employees utilise its services and to inform policy decisions on whether legislative changes should be introduced. 
It will be appropriate for the social partners to assess their information needs. An expansion of the CMS database to collect additional information would impose additional costs and further stretch the resources of the administration. An alternative approach would be to conduct further research by means such as qualitative analysis, case-studies and the analysis of individual arbitration decisions. 


\section{References}

Benjamin, P. 1994. 'Legal Representation in Labour Courts' (1994) 15 ILJ 250

Bhorat, H., Lundall, P. \& Rospabé, S. 2002. "The South African Labour Market: Economic and Legislative Considerations" Employment Paper 2002/32. ILO 2002

Blumrosen, A. 1993. "Modern Law: The Law of Transmission System and Equal Employment Opportunity" (Madison, Wisconsin 1993).

Buirski. 1995. Draft Labour Relations Bill 1995-The case for legal representation at its proposed for a dispute resolution (1995) ILJ 529.

Cheadle, H. 2005. "Regulated flexibility and small business revisiting the LRA \& the BCEA".

Collier, D. 2003. 'The Right to Legal Representation under the LRA' (2003) ILJ 753

Collier, D. 2005. Collier The Right to Legal Representation at the Commission for Conciliation, Mediation \& Arbitration and at disciplinary hearings (2005)26/LJ.

Department of Labour. 2004: "Synthesis Report: Changing Nature of Work and 'Atypical' Forms of Employment in South Africa"

Grogan, J. 2005. "Stalled Reviews: Lessons by the DOL" Employment Law (October 2005) 16.

Hertz, T. 2004. "Have Minimum Wages Benefited South Africa's Domestic Service Workers?" Development Policy Research Unit: Forum Paper 13-15 October 2004.

ILO 2003. Report V: The Scope of Employment Relationship. International Labour Conference, $91^{\text {st }}$ Session. Geneva: International Labour Office.

ILO 2005. Report V (1): The Employment Relationship. International Labour Conference, $95^{\text {th }}$ Session. Geneva: International Labour Office.

Le Roux, .PAK, "Dismissal for Misconduct: Some Reflections" (2004) 25 ILJ 868. 
Mischke C "Calculating compensation for unfair dismissal: quantifying just and equitable compensation" Contemporary Labour Law Vol 15 No.3 October 2005.

Smythe N 'Legal Representation at the CCMA-Latest Developments' (2003) 24 ILJ 1975

Theron J, "Intermediary or Employer? Labour Brokers and the Triangular Employment Relationship." (2005) 26 ILJ 618.

Tokiso Review 2005-6. 


\section{Statistical Annex}

Index:

Table A1: Determinative process of dismissal cases by region 2001/02

Table A2: Determinative process of dismissal cases by region 2003/04

Table A3: Determinative process of dismissal cases by region 2004/05

Table A4: Determinative process of dismissal cases by main sector 2001/02 Table A5: Determinative process of dismissal cases by main sector 2003/04 Table A6: Determinative process of dismissal cases by main sector 2004/05

Table A7: Outcome of dismissal cases by region 2001/02

Table A8: Outcome of dismissal cases by region 2003/04

Table A9: Outcome of dismissal cases by region 2004/05

Table A10: Outcome of dismissal cases by main sector 2001/02

Table A11: Outcome of dismissal cases by main sector 2003/04

Table A12: Outcome of dismissal cases by main sector 2004/05 
Table A1: Determinative Process of Dismissal Cases by Region 2001/02

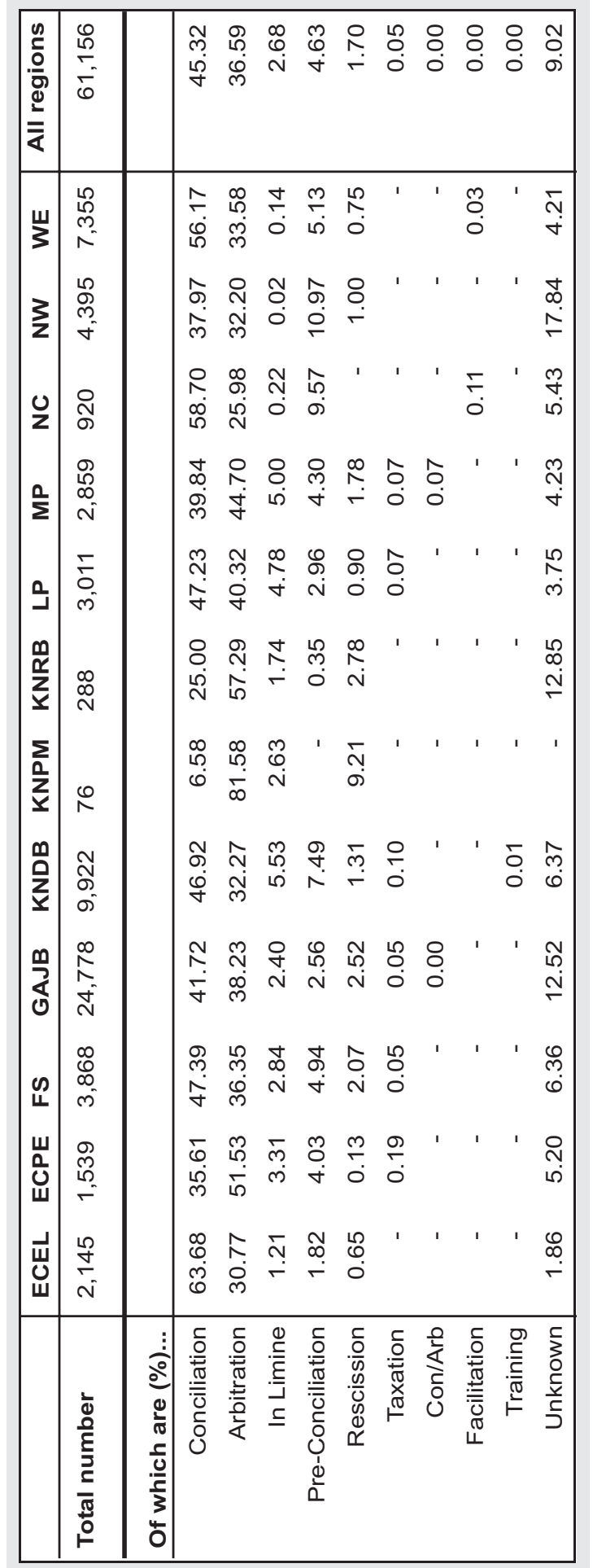


Table A2: Determinative Process of Dismissal Cases by Region 2003/04

\begin{tabular}{|c|c|c|c|c|c|c|c|c|c|c|c|c|c|c|c|c|}
\hline 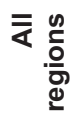 & $\begin{array}{l}0 \\
8 \\
0 \\
80 \\
0 \\
0\end{array}$ & & $\begin{array}{l}\stackrel{\circ}{0} \\
\ddot{N}\end{array}$ & $\begin{array}{l}\qquad 0 \\
0 \\
\infty \\
\infty\end{array}$ & $\stackrel{\infty}{\infty}$ & 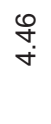 & $\begin{array}{l}\stackrel{\forall}{ } \\
\stackrel{\forall}{ }\end{array}$ & $\begin{array}{l}8 \\
0 \\
0\end{array}$ & $\begin{array}{l}\stackrel{0}{N} \\
\stackrel{N}{N}\end{array}$ & $\stackrel{\circ}{\circ}$ & $\begin{array}{l}\sigma_{0} \\
\end{array}$ & $\stackrel{N}{\circ}$ & : & $\begin{array}{l}8 \\
0 \\
0\end{array}$ & 임 & $\begin{array}{l}\mathscr{M} \\
\infty \\
0\end{array}$ \\
\hline ऍ & $\begin{array}{l}\widetilde{N} \\
\varnothing^{\circ} \\
\infty\end{array}$ & & 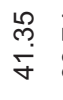 & $\begin{array}{l}N \\
\infty \\
\infty \\
\infty\end{array}$ & $\stackrel{\hat{n}}{\stackrel{n}{0}}$ & $\begin{array}{l}\stackrel{\odot}{\sim} \\
\stackrel{+}{*}\end{array}$ & $\underset{\sim}{\stackrel{N}{N}}$ & $\begin{array}{l}\text { ठ } \\
\text { ○ }\end{array}$ & $\begin{array}{l}\hat{0} \\
\dot{m}\end{array}$ & 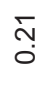 & ' & $\stackrel{\circ}{\check{0}}$ & & ' & ' & 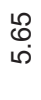 \\
\hline z & 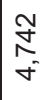 & & $\stackrel{\text { L }}{\stackrel{2}{\rightleftharpoons}}$ & $\begin{array}{l}\text { ले } \\
\infty \\
\infty\end{array}$ & $\begin{array}{l}\infty \\
\stackrel{\infty}{0}\end{array}$ & $\begin{array}{l}\stackrel{\infty}{\infty} \\
\ddot{m}\end{array}$ & 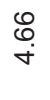 & $\check{0}$ & 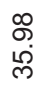 & $\stackrel{m}{\circ}$ & $\underset{\circlearrowright}{\widetilde{O}}$ & $\begin{array}{l}\mathscr{0} \\
\stackrel{0}{0}\end{array}$ & & ' & I & $\underset{\text { is }}{\stackrel{N}{2}}$ \\
\hline U & $\underset{\check{N}}{\stackrel{\Sigma}{\sim}}$ & & $\begin{array}{l}\stackrel{\sim}{0} \\
\stackrel{\infty}{\infty} \\
\stackrel{\infty}{\leftarrow}\end{array}$ & $\stackrel{\curvearrowright}{\stackrel{\infty}{\infty}}$ & $\stackrel{\infty}{\check{r}}$ & $\begin{array}{l}\stackrel{\infty}{\stackrel{0}{\circ}} \\
\stackrel{0}{\circ}\end{array}$ & 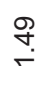 & ' & $\begin{array}{l}\text { 이 } \\
\infty \\
\infty\end{array}$ & $\begin{array}{l}\infty \\
\stackrel{0}{0} \\
\stackrel{0}{0}\end{array}$ & ' & $\stackrel{n}{\check{0}}$ & & ' & ' & 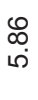 \\
\hline$\frac{0}{\Sigma}$ & $\begin{array}{l}\mathfrak{N} \\
\infty \\
m \\
m \\
m\end{array}$ & & $\begin{array}{l}\stackrel{\sim}{\circ} \\
\stackrel{m}{\sim}\end{array}$ & $\begin{array}{l}\text { mె } \\
\text { ळ. }\end{array}$ & $\begin{array}{l}\qquad 0 \\
0 \\
0\end{array}$ & $\stackrel{\mathfrak{N}}{\stackrel{N}{N}}$ & $\stackrel{5}{i s}$ & $\stackrel{\infty}{\circ}$ & $\begin{array}{l}\infty \\
0 \\
\dot{ల} \\
\dot{m}\end{array}$ & సָ & $\stackrel{\text { O̊ }}{\circ}$ & $\underset{ָ}{\grave{o}}$ & & ' & ' & $\underset{m}{\stackrel{P}{\rho}}$ \\
\hline a & $\begin{array}{l}\text { o } \\
\text { 它 } \\
m^{\circ}\end{array}$ & & $\begin{array}{l}\text { o } \\
\stackrel{+}{+}\end{array}$ & 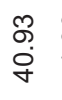 & 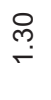 & 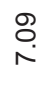 & $\stackrel{\hat{m}}{\mathrm{~N}}$ & $\begin{array}{l}\mathscr{0} \\
\dot{0}\end{array}$ & 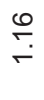 & $\underset{\circ}{\check{0}}$ & ' & $\begin{array}{l}\text { O̊ } \\
\text { Oे }\end{array}$ & $\begin{array}{l}\mathscr{0} \\
\stackrel{0}{0}\end{array}$ & ' & ' & $\underset{\sim}{\stackrel{\sim}{*}}$ \\
\hline $\begin{array}{l}\infty \\
\underline{\underline{\alpha}} \\
\underline{\underline{x}}\end{array}$ & $\stackrel{0}{\stackrel{0}{m}} \stackrel{-}{=}$ & & 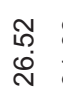 & $\frac{\infty}{\circ}$ & $\stackrel{N}{\stackrel{N}{\leftarrow}}$ & ' & $\begin{array}{l}\bar{\infty} \\
\stackrel{N}{N}\end{array}$ & ' & $\begin{array}{l}\text { ల్ } \\
\text { लm }\end{array}$ & $\stackrel{\infty}{\infty}$ & ' & ' & ' & ' & ' & $\begin{array}{l}\text { J } \\
+\end{array}$ \\
\hline $\begin{array}{l}\sum_{0} \\
\sum \underline{z}\end{array}$ & 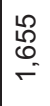 & & $\begin{array}{l}0 \\
\dot{0} \\
\infty\end{array}$ & 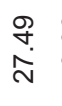 & $\begin{array}{l}\mathscr{0} \\
0\end{array}$ & $\begin{array}{l}\mathscr{0} \\
\stackrel{0}{0}\end{array}$ & 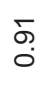 & ' & $\begin{array}{l}\underset{+}{+} \\
\text { ָे }\end{array}$ & ' & ' & ' & ' & ' & ' & مُ \\
\hline $\begin{array}{l}\text { 号 } \\
\text { z }\end{array}$ & $\frac{-}{\infty}$ & & $\begin{array}{l}\stackrel{N}{N} \\
0 \\
0\end{array}$ & $\begin{array}{l}\widetilde{P} \\
\stackrel{\infty}{0} \\
\infty \\
\infty\end{array}$ & $\begin{array}{l}\circ \\
\stackrel{0}{0} \\
0\end{array}$ & 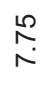 & $\underset{\sim}{\stackrel{\sim}{*}}$ & 웅 & $\begin{array}{l}0 \\
@ \\
\infty \\
\infty\end{array}$ & $\begin{array}{l}\infty \\
\stackrel{0}{0}\end{array}$ & O̊. & $\begin{array}{l}\infty \\
\stackrel{0}{0} \\
\stackrel{0}{0}\end{array}$ & 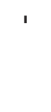 & ' & ס. & $\stackrel{\mathscr{P}}{\stackrel{\leftrightarrow}{*}}$ \\
\hline$\frac{\llcorner}{\frac{1}{\alpha}}$ & ๗ె & & $\begin{array}{l}\stackrel{\circ}{\circ} \\
\stackrel{\leftrightarrow}{+}\end{array}$ & $\begin{array}{l}8 \\
\stackrel{\rho}{\circ}\end{array}$ & $\stackrel{m}{m}$ & ' &  & ' & $\frac{m}{m}$ & ' & ' & ' & ' & ' & ' & ' \\
\hline 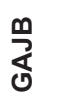 & 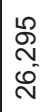 & & $\frac{0}{\stackrel{2}{N}}$ & 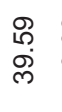 & $\begin{array}{l}\infty \\
\stackrel{\infty}{\circ} \\
\stackrel{0}{0}\end{array}$ & $\begin{array}{l}\text { م. } \\
\text { లై }\end{array}$ & $\underset{i \infty}{\infty}$ & ஜ̊ & $\begin{array}{l}\Gamma \\
\stackrel{1}{\rho}\end{array}$ & $\stackrel{\infty}{\circ} \stackrel{0}{\circ}$ & ${ }_{0}^{5}$ & $\stackrel{\circ}{\circ}$ & ' & ৪ & ' & $\begin{array}{l}\mathbb{\sigma} \\
\stackrel{\circ}{\circ}\end{array}$ \\
\hline$\underset{4}{\mathscr{W}}$ & 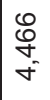 & & 㝏 & $\begin{array}{l}\mathscr{Q} \\
\infty \\
\infty\end{array}$ & $\begin{array}{l}\text { fo } \\
\stackrel{0}{0}\end{array}$ & $\stackrel{\text { f }}{\text { r }}$ & 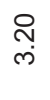 & io & 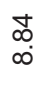 & ' & $\begin{array}{l}\text { Oे } \\
\text {. }\end{array}$ & 今o & & $\begin{array}{l}\text { Õ } \\
\text { ơ }\end{array}$ & ' & $\begin{array}{l}\mathscr{S} \\
\oplus\end{array}$ \\
\hline 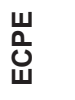 & $\frac{g}{\stackrel{g}{+}}$ & & 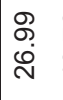 & $\begin{array}{l}\mathfrak{N} \\
\stackrel{N}{Y}\end{array}$ & $\begin{array}{c}\tilde{O} \\
\text { Oे }\end{array}$ & 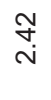 & $\begin{array}{l}\stackrel{0}{\varrho} \\
\stackrel{\sim}{\sim}\end{array}$ & $\begin{array}{l}\text { L } \\
0\end{array}$ & $\frac{\text { O) }}{\circ}$ & $\begin{array}{l}\text { og } \\
\circ\end{array}$ & 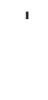 & $\begin{array}{l}\stackrel{0}{0} \\
\stackrel{0}{0}\end{array}$ & & ' & ' & 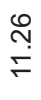 \\
\hline \multirow[t]{2}{*}{ 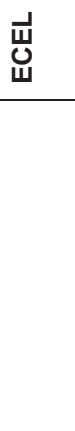 } & $\begin{array}{l}\infty \\
\stackrel{\infty}{\infty} \\
\stackrel{\infty}{-} \\
\sim\end{array}$ & & $\begin{array}{l}\stackrel{N}{N} \\
\text { N }\end{array}$ & $\begin{array}{l}\widetilde{\mho} \\
\dot{\forall} \\
\dot{\forall}\end{array}$ & $\begin{array}{l}\stackrel{\infty}{\infty} \\
\stackrel{1}{\wedge}\end{array}$ & $\begin{array}{l}\infty \\
\text { m. } \\
i\end{array}$ & $\stackrel{\substack{\infty \\
\sim}}{\sim}$ & ' & $\begin{array}{l}\stackrel{\$}{\infty} \\
\sim \\
\sim\end{array}$ & مo & 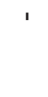 & 今o & & & ' & 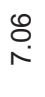 \\
\hline & 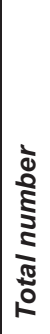 & 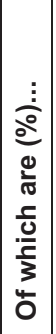 & 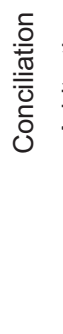 & 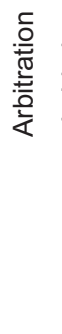 & 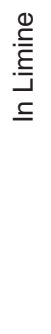 & 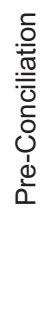 & 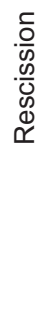 &  & $\begin{array}{l}\frac{0}{2} \\
\text { ¿ } \\
0 \\
0\end{array}$ & 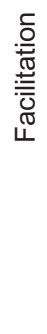 & 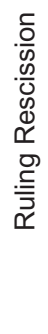 &  & 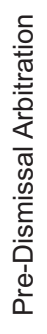 & 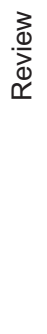 & $\frac{\overrightarrow{0}}{\overline{\bar{\varpi}}}$ & $\begin{array}{l}\frac{5}{0} \\
\frac{5}{5} \\
\text { J }\end{array}$ \\
\hline
\end{tabular}


Table A3: Determinative Process of Dismissal Cases by Region 2004/05

\begin{tabular}{|c|c|c|c|c|c|c|c|c|c|c|c|c|c|c|c|}
\hline 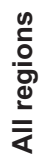 & $\begin{array}{l}\text { D } \\
\text { N } \\
\infty^{\circ}\end{array}$ & & $\begin{array}{l}\hat{N} \\
\infty \\
\stackrel{\infty}{\infty}\end{array}$ & 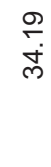 & $\stackrel{m}{m}$ & $\stackrel{\text { mp }}{\text { m. }}$ & 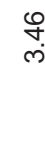 & 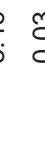 & 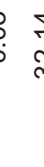 & & $\frac{}{\circ}$ & $\stackrel{\mathscr{O}}{0}$ & $\frac{}{\circ}$ & $\begin{array}{l}8 \\
0\end{array}$ & $\underset{\text { Di }}{8}$ \\
\hline$\underset{3}{\mathbf{3}}$ & $\frac{1}{2}$ & & $\begin{array}{l}\hat{\sigma} \\
\text { sల }\end{array}$ & $\begin{array}{l}\text { o. } \\
\text { iे }\end{array}$ & $\stackrel{\stackrel{\circ}{\stackrel{2}{\leftarrow}}}{r}$ & $\frac{0}{m}$ & $\bar{N}$ & je & $\begin{array}{l}3 \\
\text { ș }\end{array}$ & & ల్లి & ' & $\stackrel{8}{\circ}$ & & $\stackrel{\infty}{0}$ \\
\hline$\frac{3}{2}$ & 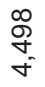 & & $\begin{array}{l}\infty \\
\stackrel{\infty}{\sim} \\
\stackrel{2}{2}\end{array}$ & $\begin{array}{l}\text { S. } \\
\text { வें }\end{array}$ & $\stackrel{m}{i}$ & 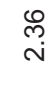 & $\begin{array}{l}\stackrel{\ominus}{\oplus} \\
\text { ले }\end{array}$ & ? & & & $\begin{array}{l}\text { N̦ } \\
0\end{array}$ & $\begin{array}{l}\text { ¿̛. } \\
\text {. }\end{array}$ & o̊. & $\begin{array}{l}\tilde{O} \\
\stackrel{0}{0}\end{array}$ & $\underset{\infty}{\infty}$ \\
\hline $\mathbf{z}$ & $\underset{\sim}{\stackrel{\text { }}{\sim}}$ & & $\begin{array}{l}\tilde{C} \\
\end{array}$ & $\begin{array}{l}\text { : } \\
\text { ¿े }\end{array}$ & 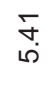 & $\stackrel{N}{\circ}$ & $\underset{\overbrace{}}{\widetilde{g}}$ & & & & $\frac{10}{\circ}$ & ' & ' & ' & $\begin{array}{l}\text { O̊ } \\
0\end{array}$ \\
\hline$\frac{0}{\Sigma}$ & $\begin{array}{l}\overline{\tilde{\delta}} \\
\bar{\infty}\end{array}$ & & $\begin{array}{l}0 \\
0 \\
\stackrel{0}{0}\end{array}$ & $\frac{\infty}{+\infty}$ & $\begin{array}{l}\infty \\
\stackrel{\infty}{0} \\
0\end{array}$ & $\underset{\infty}{\infty}$ & $\begin{array}{l}\text { ¿े } \\
\text { is }\end{array}$ & & & $\begin{array}{l}\text { D. } \\
\text { : } \\
\text { if }\end{array}$ & $\begin{array}{l}\text { N̦ } \\
\text { ○ }\end{array}$ & ' & $\frac{\gamma}{\sigma}$ & ס̊: & $\underset{\widetilde{N}}{\stackrel{\sim}{+}}$ \\
\hline ב & $\begin{array}{l}\text { N } \\
\text { N } \\
\text { N }\end{array}$ & & $\begin{array}{l}\infty \\
\infty \\
\tilde{m} \\
\end{array}$ & $\begin{array}{l}\stackrel{R}{0} \\
\infty \\
\infty\end{array}$ & $\begin{array}{l}\stackrel{0}{0} \\
\stackrel{0}{0}\end{array}$ & $\begin{array}{l}\stackrel{\mathfrak{R}}{0} \\
\stackrel{0}{0}\end{array}$ & $\stackrel{\text { D }}{i}$ & & & & : & O̊ & $\begin{array}{l}\mathscr{0} \\
0\end{array}$ & ' & $\begin{array}{l}\text { ల్ } \\
\text { ம் }\end{array}$ \\
\hline 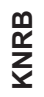 & 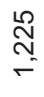 & & $\begin{array}{l}\mathscr{Q} \\
\stackrel{m}{\leftarrow}\end{array}$ & $\begin{array}{l}\mathscr{g} \\
\stackrel{\leftrightarrow}{0}\end{array}$ & $\stackrel{\Gamma}{\leftarrow}$ & $\stackrel{m}{\text { m. }}$ & $\stackrel{\sim}{\check{N}}$ & j & 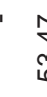 & है. & 1 & ' & ' & 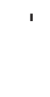 & $\underset{\sim}{\sigma}$ \\
\hline$\frac{\sum}{\underline{Z}}$ & $\underset{\widetilde{N}}{\tilde{N}}$ & & $\begin{array}{l}\bar{\sigma} \\
\infty \\
\infty\end{array}$ & 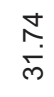 & 户্ & $\begin{array}{l}\text { p } \\
\text { m. }\end{array}$ & $\stackrel{10}{m}$ & 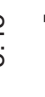 & o & & ' & ' & $\stackrel{1}{0}$ & ' & 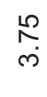 \\
\hline $\begin{array}{l}\text { 号 } \\
\text { Z }\end{array}$ & $\frac{N}{\frac{N}{\sigma}}$ & & $\begin{array}{l}\alpha \\
\infty \\
\infty\end{array}$ & $\frac{\delta}{\dot{m}}$ & $\begin{array}{l}\text { \& } \\
\stackrel{0}{0}\end{array}$ & 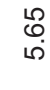 & $\stackrel{\overbrace = 0}{\sim}$ & P & s? & Sُ & $\begin{array}{l}\widetilde{O} \\
\circ\end{array}$ & $\stackrel{\text { م) }}{\circ}$ & ¿্ & 1 & $\begin{array}{l}\text { m. } \\
\text { m. }\end{array}$ \\
\hline$\frac{2}{6}$ & $\begin{array}{l}\tilde{N} \\
\text { } \\
\sim \\
\sim\end{array}$ & & $\underset{\check{J}}{\check{J}}$ & 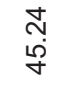 & $\stackrel{\rho}{\rho}$ & $\underset{\leftarrow}{\stackrel{\sim}{*}}$ & $\stackrel{\text { \&े }}{\text { ले }}$ & & 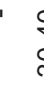 & : & $\begin{array}{l}\text { ¿ } \\
\stackrel{0}{0}\end{array}$ & ' & $\begin{array}{l}\text { J } \\
\dot{0}\end{array}$ & ' & مִ \\
\hline 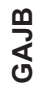 & $\begin{array}{l}\text { D } \\
\stackrel{N}{N} \\
\mathcal{L} \\
N\end{array}$ & & $\underset{⿱ 乛}{\tilde{\sigma}}$ & $\begin{array}{l}\text { m } \\
\text { ల్ }\end{array}$ & $\begin{array}{l}\text { m) } \\
\text { ம. }\end{array}$ & $\stackrel{\curvearrowright}{\check{r}}$ & $\frac{n}{\sim}$ & ? & $\begin{array}{l}b \\
\end{array}$ & م. & ' & ' & $\underset{\leftarrow}{\check{0}}$ & ' & 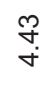 \\
\hline D & $\underset{\sigma}{\stackrel{\sigma}{\sigma}}$ & & $\begin{array}{l}\text { న్ } \\
\text { ల్ }\end{array}$ & $\begin{array}{l}\mathscr{8} \\
\stackrel{\infty}{\infty}\end{array}$ & $\stackrel{8}{\wedge}$ & ه্ল & مे & ? & 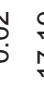 & : & $\begin{array}{l}\stackrel{2}{0} . \\
\circ\end{array}$ & $\begin{array}{l}\text { L̊ } \\
0 \\
0\end{array}$ & $\begin{array}{l}\hat{0} \\
0\end{array}$ & ' & $\frac{0}{\stackrel{6}{\rho}}$ \\
\hline 山् & g & & \begin{tabular}{l}
\multirow{N}{*}{} \\
$\stackrel{\sim}{ }$
\end{tabular} & $\begin{array}{l}\text { D } \\
\text { pि }\end{array}$ & $\begin{array}{l}\text { N } \\
\stackrel{\sim}{N}\end{array}$ & مે & $\stackrel{\hat{N}}{\hat{N}}$ & j & & & 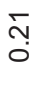 & ' & $\begin{array}{l}\text { ల్ } \\
\text { o. }\end{array}$ & 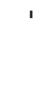 & 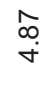 \\
\hline$\vec{\omega}$ & 웅 & & $\begin{array}{l}\stackrel{Q}{2} \\
\dot{d}\end{array}$ & $\begin{array}{l}\mathscr{L} \\
\infty \\
\stackrel{p}{\infty}\end{array}$ & $\stackrel{\text { ִֻ }}{\wedge}$ & $\stackrel{\text { \& }}{\sim}$ & $\stackrel{\text { ڤ̊ }}{\rho}$ & & 5 & : & ' & ' & $\stackrel{N}{\check{O}}$ & ' & $\frac{0}{\dot{\theta}}$ \\
\hline &  & 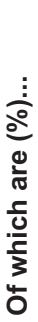 & 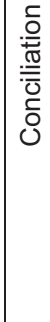 &  & 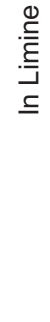 & 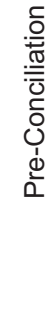 & 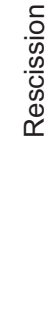 & : & $\begin{array}{l}0 \\
0 \\
0 \\
0 \\
0\end{array}$ & 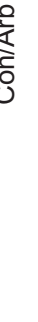 & 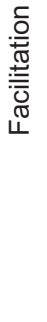 & 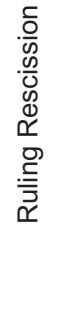 & 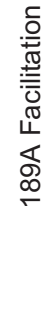 & 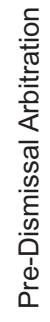 & $\begin{array}{l}\frac{5}{3} \\
\frac{5}{5} \\
\text { s }\end{array}$ \\
\hline
\end{tabular}


Table A4: Determinative Process of Dismissal Cases by Main Sectors 2001/02

\begin{tabular}{|c|c|c|c|c|c|c|c|c|c|c|}
\hline 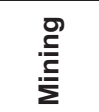 & $\begin{array}{l}\stackrel{0}{ } \\
\text { i }\end{array}$ & &  & $\frac{m}{m}$ & $\begin{array}{l}\stackrel{\odot}{\bullet} \\
\dot{+}\end{array}$ & $\stackrel{\text { for }}{\leftarrow}$ & 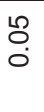 & ' & & $\begin{array}{l}\stackrel{m}{f} \\
\stackrel{0}{\circ}\end{array}$ \\
\hline 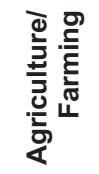 & $\stackrel{\infty}{\circ}$ & & 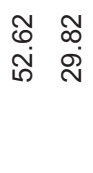 & $\underset{\sim}{\stackrel{N}{N}}$ & $\begin{array}{l}\hat{6} \\
\dot{m}\end{array}$ & $\stackrel{\bar{N}}{\leftarrow}$ & : & ' & & চ \\
\hline 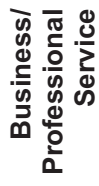 & $\begin{array}{l}\text { Tे } \\
\text { N } \\
\text { N }\end{array}$ & & 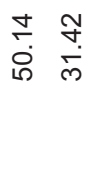 & 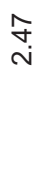 & $\begin{array}{l}\text { ه } \\
\text { m. }\end{array}$ & 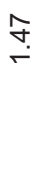 & $\underset{0}{\check{O}}$ & ' & & 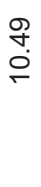 \\
\hline 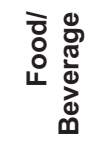 & $\begin{array}{l}L \\
\infty \\
\infty \\
\sim\end{array}$ & & $\begin{array}{ll}0 & m \\
0 & \infty \\
\dot{\sigma} & 0\end{array}$ & 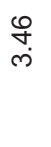 & $\underset{\sim}{\Gamma}$ & 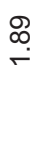 & $\begin{array}{l}\hat{0} \\
0\end{array}$ & ' & & 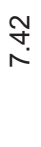 \\
\hline 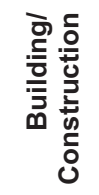 & $\frac{\stackrel{L}{\circ}}{\stackrel{0}{\sigma}}$ & & 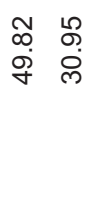 & $\stackrel{\substack{\sim \\
\sim}}{\sim}$ & $\begin{array}{l}\mathscr{\leftrightarrow} \\
\dot{+}\end{array}$ & $\stackrel{\bar{\infty}}{\leftarrow}$ & $\begin{array}{l}\widetilde{0} \\
\text { Oे }\end{array}$ & ' & & 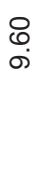 \\
\hline 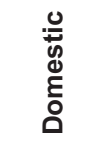 & 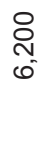 & & 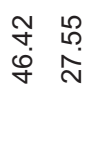 & $\stackrel{\stackrel{m}{N}}{\sim}$ & $\stackrel{\infty}{\stackrel{\infty}{ }}$ & $\stackrel{\circ}{\check{r}}$ & ' & ' & & $\begin{array}{l}\infty \\
\varrho \\
\oplus\end{array}$ \\
\hline 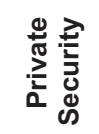 & $\begin{array}{l}\infty \\
0 \\
ల \\
0\end{array}$ & & 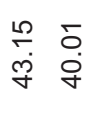 & $\stackrel{\infty}{\stackrel{\infty}{N}}$ & $\stackrel{\infty}{\substack{\sim \\
v}}$ & $\stackrel{\text { ㅇ }}{\text { D }}$ & $\begin{array}{l}\infty \\
\stackrel{0}{0} \\
0\end{array}$ & ' & & $\underset{\sigma}{\sigma}$ \\
\hline \multirow[t]{2}{*}{$\begin{array}{l}\overline{\bar{\pi}} \\
\bar{d} \\
\widetilde{L}\end{array}$} & 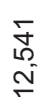 & & 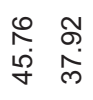 & $\underset{\sim}{\check{c}}$ & $\stackrel{f}{\stackrel{f}{f}}$ & 苫 & ס̊. & ס & & $\begin{array}{l}œ \\
\stackrel{\infty}{\Lambda}\end{array}$ \\
\hline & 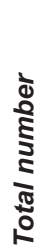 & 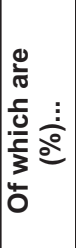 & 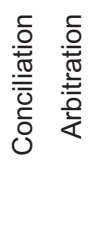 & 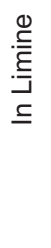 & 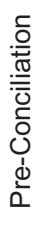 & 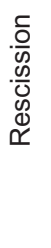 &  & $\begin{array}{l}\frac{0}{4} \\
\text { ○े } \\
\text { ن }\end{array}$ & 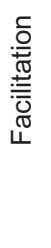 & $\begin{array}{l}\text { ईz } \\
0 \\
\frac{5}{5} \\
\text { J }\end{array}$ \\
\hline
\end{tabular}


Table A5: Determinative Process of Dismissal Cases by Main Sectors 2003/04

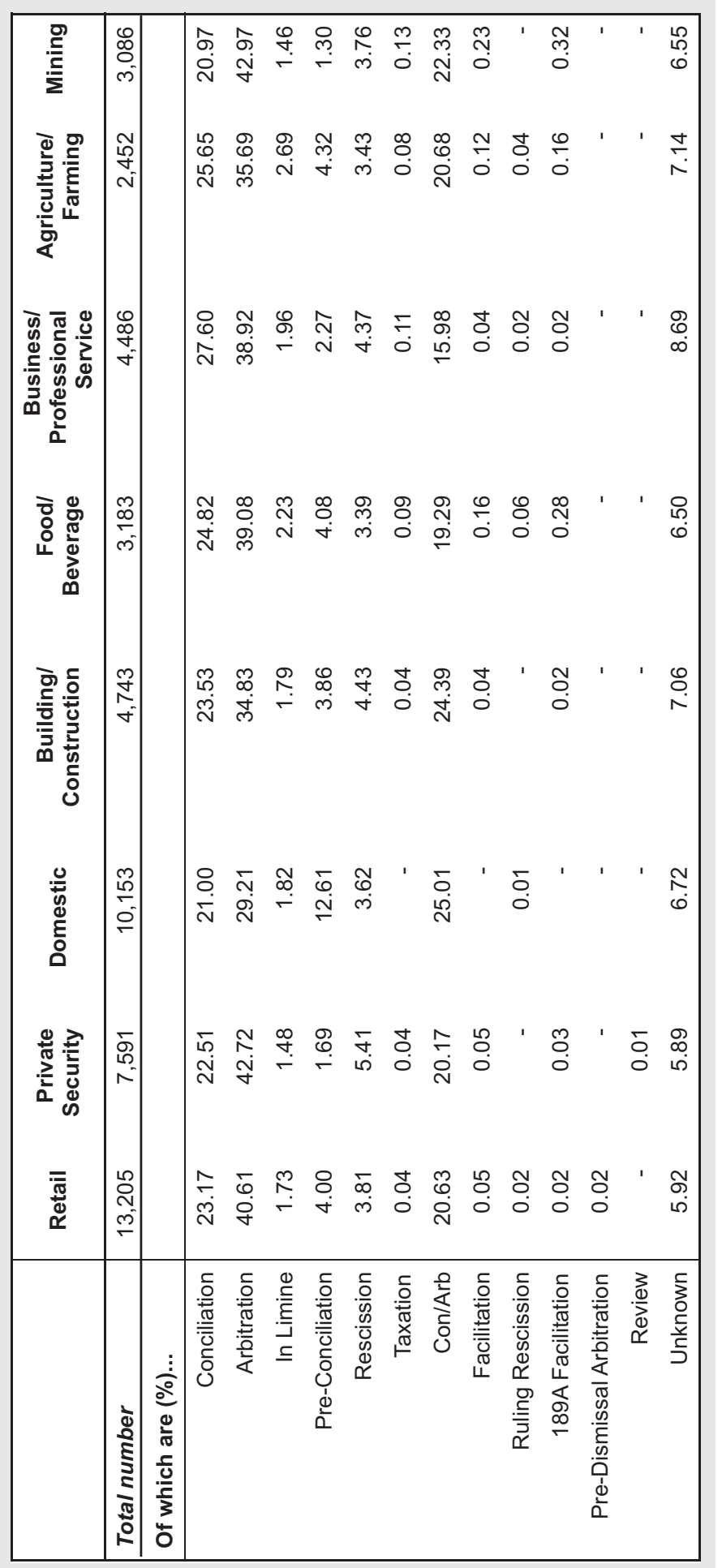


Table A6: Determinative Process of Dismissal Cases by Main Sectors 2004/05

\begin{tabular}{|c|c|c|c|c|c|c|c|c|c|c|c|c|c|}
\hline 㝘 & $\begin{array}{l}m \\
\stackrel{m}{\sigma} \\
m\end{array}$ & & 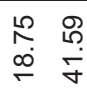 & $\underset{\dot{m}}{\stackrel{8}{ }}$ & 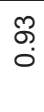 & 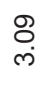 & & 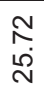 & స় & Oִ & 음 & & $\begin{array}{l}\text { J } \\
0\end{array}$ \\
\hline 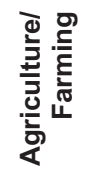 & $\begin{array}{l}8 \\
\varnothing \\
m\end{array}$ & &  & $\begin{array}{l}\bar{\infty} \\
\dot{m}\end{array}$ & $\stackrel{\sim}{\sim}$ & 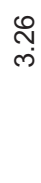 & ' & 官 & ণ্ণ & 今o & 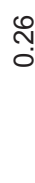 & $\stackrel{\text { Oे }}{0}$ & $\stackrel{\substack{? \\
r}}{\stackrel{2}{r}}$ \\
\hline 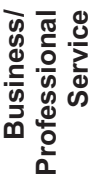 & $\begin{array}{l}\text { W } \\
\text { مે } \\
\omega^{\circ}\end{array}$ & & 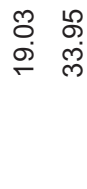 & חొ & $\stackrel{\infty}{\stackrel{\infty}{\sim}}$ & $\underset{\text { d }}{\mathbb{f}}$ & ஜ̊ & $\underset{\infty}{\stackrel{\infty}{\infty}}$ & $\underset{0}{\mathscr{0}}$ & 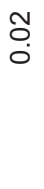 & 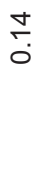 & ' & 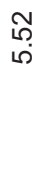 \\
\hline 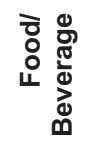 & $\begin{array}{l}\stackrel{m}{\tilde{m}} \\
\tilde{m}\end{array}$ & & 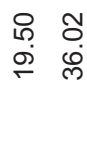 & 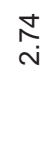 & $\frac{\circ}{\dot{m}}$ & 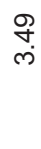 & O̊ & in & 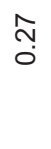 & $\begin{array}{l}\dddot{0} \\
0\end{array}$ & $\stackrel{N}{\leftarrow}$ & ' & $\stackrel{\infty}{\leftarrow}$ \\
\hline 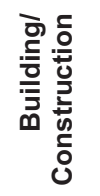 & $\begin{array}{l}0 \\
0 \\
0 \\
10\end{array}$ & & 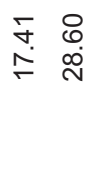 & $\begin{array}{l}\stackrel{\infty}{\infty} \\
\dot{m}\end{array}$ & $\underset{+}{\stackrel{+}{\circ}}$ & 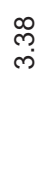 & ' & 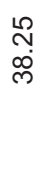 & $\begin{array}{l}\text { Oे } \\
\text { ○ }\end{array}$ & ' & $\stackrel{\sim}{\widetilde{O}}$ & ' & 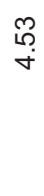 \\
\hline 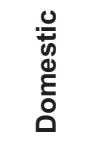 & $\frac{8}{\check{\sigma}}$ & & 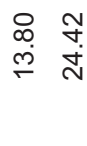 & $\stackrel{\text { ̊․ }}{\stackrel{+}{+}}$ & $\begin{array}{l}9 \\
\stackrel{9}{\infty} \\
\infty\end{array}$ & $\underset{\text { N }}{\text { N }}$ & ' & $\frac{m}{\dot{q}}$ & ' & రo & ' & ' & fे \\
\hline 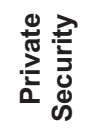 & $\frac{\infty}{\infty}$ & & 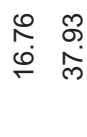 & $\begin{array}{l}\infty \\
\stackrel{\infty}{\infty}\end{array}$ & مْم & $\underset{\sim}{\tilde{\sigma}}$ & ণั & 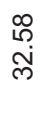 & ' & $\stackrel{0}{\circ}$ & $\begin{array}{l}\text { O্ } \\
\end{array}$ & $\vec{v}$ & $\begin{array}{l}\infty \\
\stackrel{\infty}{\infty}\end{array}$ \\
\hline \multirow[t]{2}{*}{$\begin{array}{l}\overline{\bar{\pi}} \\
\overline{ \pm} \\
\bar{x}\end{array}$} & $\begin{array}{l}\mathscr{D} \\
\infty \\
0 \\
\stackrel{N}{\sim} \\
\stackrel{1}{\sim}\end{array}$ & & $\begin{array}{ll}\text { N̦ } & \text { ల్ } \\
\text { iे } & \stackrel{n}{n}\end{array}$ & 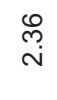 & $\stackrel{m}{\sim}$ & $\begin{array}{l}\mathscr{Q} \\
\stackrel{m}{0}\end{array}$ & $\stackrel{\dddot{m}}{0}$ & $\begin{array}{l}\hat{m} \\
\text { oे }\end{array}$ & ָ̊ & O̊. & 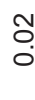 & ర్ర & $\underset{+}{\stackrel{\sigma}{+}}$ \\
\hline & 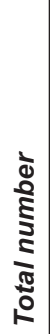 & 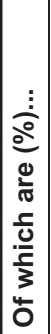 & 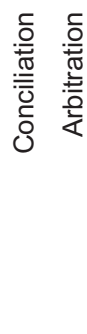 & 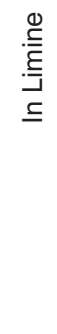 & 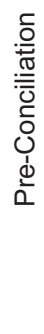 & 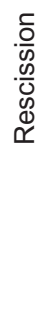 & 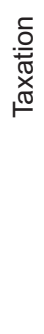 & 这 & 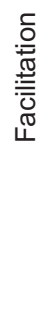 & 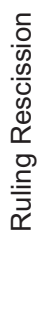 & 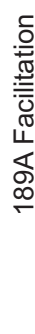 & $\begin{array}{l}\frac{0}{0} \\
\frac{0}{0} \\
\frac{0}{2} \\
\frac{1}{0}\end{array}$ & $\begin{array}{l}\frac{5}{5} \\
\frac{5}{5} \\
\text { 5 }\end{array}$ \\
\hline
\end{tabular}


Table A7: Outcome of Dismissal Cases by Region 2001/02

\begin{tabular}{|c|c|c|c|c|c|c|c|c|c|c|c|c|c|c|c|c|}
\hline 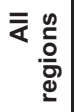 & $\begin{array}{l}0 \\
\stackrel{8}{6} \\
- \\
-\end{array}$ & & $\begin{array}{l}\bar{N} \\
\text { ¿্ల }\end{array}$ & 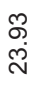 & مُ & $\begin{array}{l}\infty \\
\stackrel{5}{\sim}\end{array}$ & $\stackrel{N}{N}$ & $\begin{array}{l}\delta \\
0 \\
0\end{array}$ & $\stackrel{m}{m}$ & 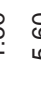 & : & $\stackrel{\substack{\infty \\
\sim}}{\sim \infty}$ & $\stackrel{+}{\stackrel{+}{r}}$ & $\stackrel{9}{ }$ & $\ddot{0}$ & $\begin{array}{l}\infty \\
\stackrel{\infty}{\circ}\end{array}$ \\
\hline щ & $\begin{array}{l}\stackrel{\leftrightarrow}{\rho} \\
\stackrel{\rho}{\sim} \\
\sim\end{array}$ & & $\begin{array}{l}\text { बे } \\
\text { ָे }\end{array}$ & 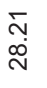 & $\overline{0}$ & 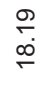 & $\frac{\infty}{\leftarrow}$ & & ङ & 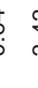 & fy & 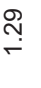 & $\begin{array}{l}\infty \\
\stackrel{0}{0} \\
\end{array}$ & $\stackrel{\infty}{\circ} \stackrel{0}{0}$ & ס̊ & 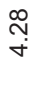 \\
\hline z & $\begin{array}{l}\stackrel{\leftrightarrow}{O} \\
m \\
\forall\end{array}$ & & $\begin{array}{l}\stackrel{\mathscr{N}}{N} \\
\stackrel{f}{*}\end{array}$ & $\begin{array}{l}\stackrel{8}{+} \\
\dot{+}\end{array}$ & ஜ̊ & $\begin{array}{l}\stackrel{\leftrightarrow}{+} \\
\stackrel{+}{+}\end{array}$ & ণ্ণি & & $\begin{array}{l}8 \\
\text { م. } \\
0\end{array}$ & ?. & ?. & $\underset{\leftarrow}{\check{c}}$ & & $\underset{O}{E}$ & ' & 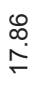 \\
\hline u & ๙ั. & & $\begin{array}{l}\text { Ñ } \\
\stackrel{0}{0}\end{array}$ & $\stackrel{\stackrel{\rho}{R}}{\stackrel{R}{\sim}}$ & & $\begin{array}{l}\text { هُ } \\
\text { مُ }\end{array}$ & $\stackrel{5}{\circ}$ & & & & م. & ָָ & & & $\underset{O}{F}$ & 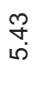 \\
\hline$\frac{0}{\Sigma}$ & 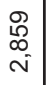 & & $\begin{array}{l}\text { षे } \\
\text { ه্ं }\end{array}$ & 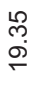 & 员 & $\begin{array}{l}\text { ठ্ } \\
\text { N }\end{array}$ & $\stackrel{ }{\circ}$ & ח̊ & $\stackrel{?}{+}$ & & N & $\stackrel{m}{\grave{i}}$ & $\begin{array}{l}\hat{p} \\
\stackrel{\rho}{ }\end{array}$ & 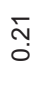 & $\stackrel{0}{\circ}$ & $\underset{\sim}{\stackrel{N}{+}}$ \\
\hline a & $\begin{array}{l}\Sigma_{0} \\
\tilde{m}\end{array}$ & & $\begin{array}{l}\stackrel{\Re}{2} \\
\stackrel{\oplus}{\oplus}\end{array}$ & $\begin{array}{l}\stackrel{+}{0} \\
\stackrel{+}{\sim}\end{array}$ & ঙ্లি & 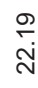 & ' & ' & $\stackrel{2}{\sim}$ & & to &  & $\underset{N}{N}$ & $\stackrel{\circ}{\circ}$ & ô. & 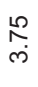 \\
\hline $\begin{array}{l}\frac{m}{\underline{x}} \\
\underset{z}{z}\end{array}$ & $\begin{array}{l}\infty \\
\stackrel{\infty}{N}\end{array}$ & & $\begin{array}{l}\text { iூ } \\
\text { Nं }\end{array}$ & $\begin{array}{l}\text { L़ } \\
\stackrel{m}{=}\end{array}$ & ' & $\begin{array}{l}\text { No } \\
\infty \\
\text { i }\end{array}$ & $\begin{array}{l}\stackrel{m}{\infty} \\
\infty\end{array}$ & ' & $\stackrel{\infty}{\stackrel{\infty}{\sim}}$ & & D. & 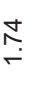 & $\stackrel{\substack{m \\
\hdashline}}{0}$ & ' & ' & $\begin{array}{l}\stackrel{\infty}{\infty} \\
\stackrel{ }{\sim}\end{array}$ \\
\hline $\begin{array}{l}\sum_{0} \\
\sum_{\underline{z}}\end{array}$ & $\stackrel{0}{\sim}$ & & $\begin{array}{l}\stackrel{9}{2} \\
\stackrel{9}{h}\end{array}$ & $\stackrel{\text { ָֻ}}{\leftarrow}$ & $\stackrel{\sim}{\sim}$ & 守 & $\begin{array}{l}\stackrel{2}{2} \\
\stackrel{b}{r}\end{array}$ & ' & $\begin{array}{l}\infty \\
\infty \\
0 \\
0\end{array}$ & 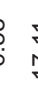 & 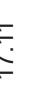 & ' & $\stackrel{\sim}{\stackrel{\sim}{\leftarrow}}$ & $\stackrel{\text { }}{\leftarrow}$ & ' & ' \\
\hline $\begin{array}{l}\text { 号 } \\
\text { z }\end{array}$ & \begin{tabular}{l}
$\widetilde{N}$ \\
\multirow{\sigma}{*}{} \\
$\sigma$
\end{tabular} & & $\begin{array}{l}\bar{N} \\
\text { bj }\end{array}$ & $\begin{array}{l}8 \\
\text { ¿े }\end{array}$ & $\stackrel{\infty}{\circ}$ & $\begin{array}{l}\bigotimes \\
\stackrel{+}{-}\end{array}$ & $\stackrel{\mathscr{S}}{-}$ & ' & ஜ. & ? & $\frac{\partial}{m}$ & $\stackrel{0}{\frac{0}{i \circ}}$ & $\underset{\text { i }}{\text { d }}$ & $\stackrel{\frac{L}{0}}{\circ}$ & $\underset{0}{\check{O}}$ & 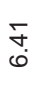 \\
\hline$\stackrel{m}{\underset{J}{+}}$ & $\begin{array}{l}\infty \\
\stackrel{\infty}{\wedge} \\
\stackrel{d}{N}\end{array}$ & & $\stackrel{\text { N }}{\stackrel{N}{N}}$ & 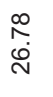 & ס. & $\begin{array}{l}\stackrel{0}{2} \\
\stackrel{\rho}{\sim}\end{array}$ & $\begin{array}{l}\text { ț } \\
\dot{\sigma}\end{array}$ & ס. & $\stackrel{\hat{O}}{i}$ & $v_{j}$ & : & $\stackrel{\vec{m}}{\vec{m}}$ & $\begin{array}{l}\stackrel{\leftrightarrow}{\circ} \\
\stackrel{\leftrightarrow}{0}\end{array}$ & $\begin{array}{l}\text { Nి } \\
\text { O }\end{array}$ & $\begin{array}{l}\stackrel{2}{\circ} \\
0\end{array}$ & 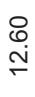 \\
\hline 告 & $\begin{array}{l}\infty \\
\& \\
\infty \\
\infty\end{array}$ & & $\frac{\text { J্ }}{\dot{\sigma}}$ & 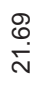 & $\stackrel{m}{\dddot{m}}$ & $\stackrel{m}{\stackrel{N}{N}}$ & $\underset{\infty}{\infty}$ & ' & مْ & & ". &  & $\stackrel{\mathscr{Q}}{\stackrel{+}{N}}$ & $\stackrel{m}{\circ}$ & $\begin{array}{l}\text { ஜ } \\
0\end{array}$ & ల్ల \\
\hline 岲 & 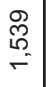 & & $\begin{array}{l}\text { ড্் } \\
\text { సે }\end{array}$ & $\begin{array}{l}\hat{0} \\
\stackrel{\infty}{\leftarrow}\end{array}$ & $\stackrel{\forall}{\stackrel{J}{0}}$ & $\begin{array}{l}\stackrel{+}{i} \\
\stackrel{q}{ }\end{array}$ & $\begin{array}{l}\mathscr{0} \\
\circ\end{array}$ & ' & $\stackrel{m}{\circ}$ & & : & ন্ন & $\begin{array}{l}\stackrel{0}{0} \\
\stackrel{0}{0}\end{array}$ & ' & $\frac{0}{\circ}$ & $\underset{\text { m్ }}{\text { m. }}$ \\
\hline \multirow[t]{2}{*}{ 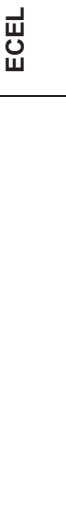 } & $\begin{array}{l}\frac{L}{f} \\
\stackrel{i}{*}\end{array}$ & & $\begin{array}{l}\infty \\
\infty \\
\infty \\
\infty \\
\infty\end{array}$ & $\begin{array}{l}\text { ळ } \\
\stackrel{\text { }}{ }\end{array}$ & $\begin{array}{l}\infty \\
\stackrel{\circ}{\circ} \\
0\end{array}$ & $\begin{array}{l}\stackrel{\rho}{\tilde{m}} \\
\stackrel{2}{\circ}\end{array}$ & $\begin{array}{l}\infty \\
\stackrel{\infty}{\circ}\end{array}$ & ஜ̊ & $\begin{array}{l}0 \\
\text { Lొ } \\
0\end{array}$ & : & fै. & $\stackrel{\vec{m}}{\stackrel{\vec{m}}{*}}$ & $\begin{array}{l}0 \\
\stackrel{\leftrightarrow}{0} \\
0\end{array}$ & o̊. & I & $\stackrel{\circ}{i}$ \\
\hline &  & $\begin{array}{l}\frac{1}{0} \\
\frac{0}{0} \\
\frac{0}{0} \\
\frac{1}{0} \\
\frac{0}{\frac{1}{3}} \\
\frac{3}{0}\end{array}$ & 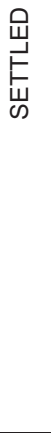 & 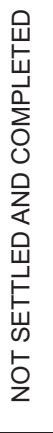 & 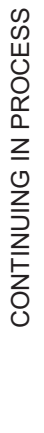 & 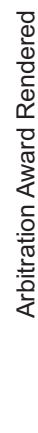 & 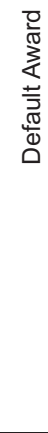 & 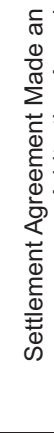 & 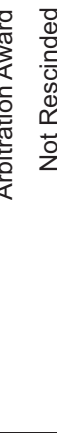 & 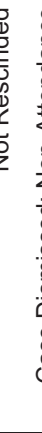 & 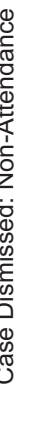 & 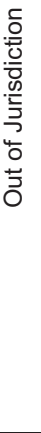 & 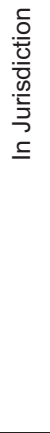 & 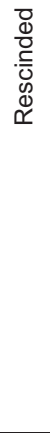 & $\begin{array}{l}\frac{\partial}{\frac{d}{0}} \\
\frac{0}{0} \\
\frac{0}{0} \\
0\end{array}$ & $\begin{array}{l}\text { s. } \\
0 \\
\frac{5}{5} \\
\text { s. }\end{array}$ \\
\hline
\end{tabular}


Table A8: Outcome of Dismissal Cases by Region 2003/04

\begin{tabular}{|c|c|c|c|c|c|c|c|c|c|c|c|c|c|c|c|c|c|c|c|}
\hline 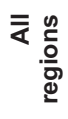 & \begin{tabular}{|l|}
8 \\
8 \\
0 \\
0 \\
0 \\
0
\end{tabular} & & $\begin{array}{l}\text { m. } \\
\infty \\
\infty\end{array}$ & $\begin{array}{l}\& \\
\infty \\
\infty\end{array}$ & $\begin{array}{l}0 \\
\stackrel{0}{0}\end{array}$ & $\begin{array}{l}\stackrel{ }{0} \\
\dot{0}\end{array}$ & $\begin{array}{l}\infty \\
\stackrel{m}{0} \\
\stackrel{0}{0}\end{array}$ & & ০ & 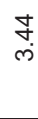 & $\delta_{0}$ & \begin{tabular}{l}
5 \\
\multirow{2}{6}{}
\end{tabular} & $c$ & & & & $\begin{array}{l}\stackrel{2}{N} \\
0\end{array}$ & & مָ \\
\hline एu & $\begin{array}{l}\widetilde{\sigma} \\
\text { ठิ } \\
\infty\end{array}$ & & $\begin{array}{l}\mathscr{L} \\
\infty \\
\dot{\sigma} \\
\end{array}$ & $\begin{array}{l}\stackrel{8}{0} \\
\stackrel{+}{0}\end{array}$ & $\begin{array}{l}R \\
0 \\
0\end{array}$ & $\begin{array}{l}\infty \\
\infty \\
\dot{\sigma}\end{array}$ & $\stackrel{\Sigma}{i n}$ & $\stackrel{1}{\circ}$ & & $\stackrel{\text { o }}{r}$ & & كُ & $\bar{c}$ & & '- & & $\stackrel{g}{\stackrel{9}{0}}$ & & $\frac{\varrho}{\dot{\theta}}$ \\
\hline$\frac{3}{2}$ & 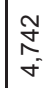 & & $\begin{array}{l}\text { fo } \\
\dot{6} \\
\stackrel{9}{2}\end{array}$ & స్ & $\frac{m}{\circ}$ & $\begin{array}{l}\tilde{\sigma} \\
\dot{0} \\
\stackrel{0}{0}\end{array}$ & 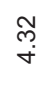 & 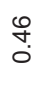 & & $\stackrel{?}{+}$ & ఠ్ & 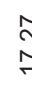 & & & 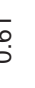 & $\stackrel{10}{5}$ & ల్లి & & 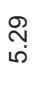 \\
\hline u & 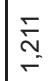 & & $\begin{array}{l}\mathcal{R} \\
0 \\
0\end{array}$ & $\stackrel{\mathscr{\rho}}{+}$ & $\frac{1}{0}$ & $\stackrel{\text { ọ }}{F}$ & $\stackrel{m}{\stackrel{n}{r}}$ & 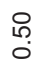 & ' & $\stackrel{\sim}{\sim}$ & & $\bar{c}$ & c & & "ู & & $\stackrel{\text { }}{\stackrel{0}{0}}$ & ' & $\begin{array}{l}\infty \\
\infty \\
i \\
i\end{array}$ \\
\hline$\frac{n}{\Sigma}$ & $\begin{array}{l}\tilde{N} \\
\stackrel{\infty}{m} \\
\tilde{m}\end{array}$ & & 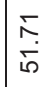 & $\stackrel{\leftrightarrow}{\stackrel{\leftrightarrow}{N}}$ & $\stackrel{\widehat{o}}{\leftarrow}$ & $\begin{array}{l}\hat{0} \\
\stackrel{\hat{\sigma}}{\circ}\end{array}$ & $\stackrel{\bullet}{\stackrel{\leftrightarrow}{~}}$ & 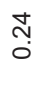 & ' & 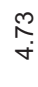 & Pُ & $\begin{array}{l}\alpha \\
\underline{5} \\
\square\end{array}$ & 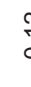 & & '. & 8 & 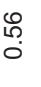 & ' & $\begin{array}{l}\stackrel{L}{\circ} \\
+\end{array}$ \\
\hline ב & $\begin{array}{l}\text { 움 } \\
\text { c. } \\
\text { r }\end{array}$ & & $\underset{\infty}{\underset{\infty}{\sigma}}$ & $\begin{array}{l}\underset{N}{\oplus} \\
\stackrel{\sigma}{0}\end{array}$ & $\stackrel{m}{\check{r}}$ & $\begin{array}{l}\stackrel{\varphi}{+} \\
\stackrel{\infty}{\leftarrow}\end{array}$ & ळo & 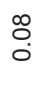 & ' & $\stackrel{\infty}{\stackrel{\infty}{\leftarrow}}$ & & 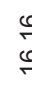 & 8 & & s. & 4 & ָָ & ' & $\begin{array}{l}\stackrel{2}{2} \\
\stackrel{1}{\circ}\end{array}$ \\
\hline $\begin{array}{l}\stackrel{\mathscr{r}}{\underline{\alpha}} \\
\underset{\underline{Z}}{\underline{y}}\end{array}$ & $\stackrel{0}{\stackrel{m}{-}}$ & & 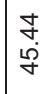 & $\underset{\infty}{\stackrel{N}{*}}$ & $\stackrel{\widetilde{N}}{0}$ & $\stackrel{\infty}{\leftarrow}$ & $\begin{array}{l}\infty \\
\dot{0}\end{array}$ & 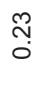 & ' & స్ & & 5 & 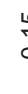 & & : & 0 & $\begin{array}{l}\infty \\
0 \\
0\end{array}$ & ' & $\underset{\text { i⿱ }}{\stackrel{R}{0}}$ \\
\hline $\begin{array}{l}\sum_{0} \\
\sum_{\underline{y}}\end{array}$ & 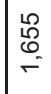 & & $\begin{array}{l}\bar{N} \\
\text { Oे }\end{array}$ & $\stackrel{\text { م }}{\leftarrow}$ & $\stackrel{\text { ্ֻ }}{\leftarrow}$ & مَ & $\begin{array}{l}\stackrel{\leftrightarrow}{m} \\
\stackrel{\rho}{\rho}\end{array}$ & $\begin{array}{l}\text { లి } \\
\text { o. }\end{array}$ &  & $\stackrel{\text { ֻ }}{0}$ & & c & & & . & & ' & ' & 8 \\
\hline 足 & $\mid \begin{array}{l}\bar{\infty} \\
\underline{0} \\
\underline{\sigma}\end{array}$ & & $\begin{array}{l}\text { N } \\
\text { î }\end{array}$ & $\stackrel{\infty}{\stackrel{\infty}{N}}$ & $\underset{0}{N}$ & 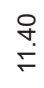 & $\begin{array}{l}\stackrel{\infty}{m} \\
\stackrel{0}{\circ}\end{array}$ & & ' & 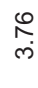 & סֶ. & ๙ิ & 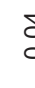 & & 趈 & 0 & ָָ & ' & 只 \\
\hline$\frac{a}{\delta}$ & $\tilde{ల}$ & & $\begin{array}{l}\tilde{\wp} \\
\stackrel{\rho}{\rho}\end{array}$ & $\begin{array}{l}\stackrel{\sim}{N} \\
\emptyset\end{array}$ & 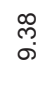 & $\begin{array}{l}\infty \\
\stackrel{\infty}{\sim} \\
\dot{亠}\end{array}$ & $\begin{array}{l}\infty \\
\stackrel{్}{\sigma}\end{array}$ & ' & ' & $\stackrel{m}{\stackrel{m}{m}}$ & & ת) & & & & 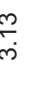 & 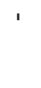 & ' & $\underset{\infty}{\stackrel{m}{\infty}}$ \\
\hline 孚 & 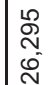 & & $\begin{array}{l}\mathcal{N} \\
\text { N } \\
\tilde{Q}\end{array}$ & $\begin{array}{l}0 \\
\text { Oొ } \\
\text { o }\end{array}$ & $\begin{array}{l}\stackrel{\infty}{\stackrel{0}{0}} \\
0\end{array}$ & 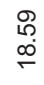 & $\stackrel{\text { مִ }}{\sim}$ & $\stackrel{m}{\circ}$ & ঃ & $\stackrel{?}{+}$ & ঃ & i & 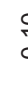 & & $\begin{array}{l}8 \\
0 \\
0\end{array}$ & $\vec{S}$ & & $\begin{array}{l}8 \\
\circ \\
\circ\end{array}$ & 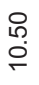 \\
\hline ஜ0 & 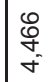 & & 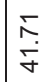 & 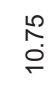 & $\begin{array}{l}\infty \\
\infty \\
0 \\
0\end{array}$ & $\begin{array}{l}\stackrel{0}{0} \\
\text { Ó }\end{array}$ & $\begin{array}{l}\stackrel{R}{0} \\
\sigma\end{array}$ & ণ্ণি & ָ̊ & $\stackrel{\infty}{\stackrel{\infty}{\leftarrow}}$ & : & s & 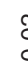 & & \begin{tabular}{c}
$\infty$ \\
\multirow{\leftarrow}{*}{} \\
d
\end{tabular} & $\hat{a}$ & $\underset{0}{\check{O}}$ & ' & $\underset{\infty}{\stackrel{N}{\infty}}$ \\
\hline 峛 & $\frac{g}{\dot{T}}$ & & N̂N & $\begin{array}{l}\stackrel{\leftrightarrow}{ } \\
\stackrel{2}{F}\end{array}$ & $\begin{array}{l}\stackrel{D}{\infty} \\
0 \\
0\end{array}$ & 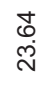 & $\stackrel{\text { pr }}{r}$ & $\begin{array}{l}0 \\
\stackrel{\leftrightarrow}{0} \\
0\end{array}$ & I & $\stackrel{\text { O }}{\stackrel{i}{N}}$ & & r & ¿ & & $\overline{\mathrm{N}}$ & 0 & 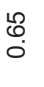 & ' & 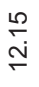 \\
\hline  & 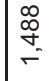 & & $\begin{array}{l}0 \\
\dot{e} \\
\dot{e}\end{array}$ & $\stackrel{N}{\stackrel{\sim}{\leftarrow}}$ & 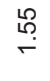 & $\begin{array}{l}\text { N̦ } \\
\text { ָे }\end{array}$ & ô. & $\stackrel{\circ}{0}$ & &  & & $\delta$ & $\delta$ & & we & & $\stackrel{m}{\circ}$ & ' & $\frac{\nabla}{\sigma}$ \\
\hline & 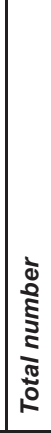 & 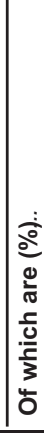 & 岂 & 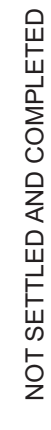 &  & 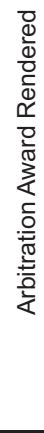 & 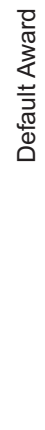 & 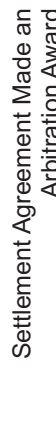 & 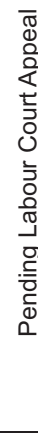 & 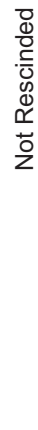 & 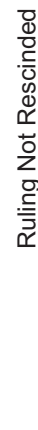 & 标 & 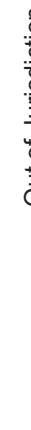 & &  & & 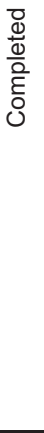 & 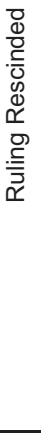 & 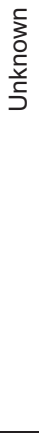 \\
\hline
\end{tabular}


Table A9: Outcome of Dismissal Cases by Region 2004/05

\begin{tabular}{|c|c|c|c|c|c|c|c|c|c|c|c|c|c|c|c|c|c|}
\hline 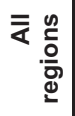 & 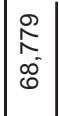 & & $\begin{array}{l}M \\
\\
0 \\
0\end{array}$ & $\begin{array}{l}\stackrel{8}{8} \\
\dot{6}\end{array}$ & $\underset{\leftarrow}{\check{g}}$ & 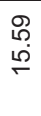 & $\frac{\sigma}{\infty}$ & $\underset{m}{m}$ & $\hat{N}$ & Õ & $\begin{array}{l}\stackrel{\leftrightarrow}{\oplus} \\
\stackrel{\leftrightarrow}{6}\end{array}$ & 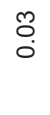 & $\stackrel{\text { \& }}{\Gamma}$ & $\begin{array}{l}\infty \\
\stackrel{\infty}{0} \\
0\end{array}$ & $\stackrel{\circ}{\circ}$ & ঃ & $\stackrel{\text { ڤ̊ }}{\circ}$ \\
\hline щ & 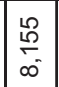 & & $\begin{array}{l}0 \\
\infty \\
\text { if }\end{array}$ & $\stackrel{g}{\stackrel{g}{\rightleftarrows}}$ & $\overline{0}$ & $\begin{array}{l}\stackrel{8}{0} \\
\stackrel{\infty}{\circ}\end{array}$ & $\stackrel{0}{\circ}$ & ঙ̊. & $\stackrel{\mathscr{N}}{\sim}$ & & 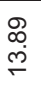 & ¿o & $\stackrel{m}{\leftarrow}$ & ల్ల & $\stackrel{\text { ? }}{\stackrel{0}{0}}$ & & $\underset{\substack{\text { N }\\
}}{ }$ \\
\hline$z$ & 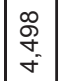 & & 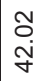 & $\stackrel{N}{\underset{\leftarrow}{\sim}}$ & đ̃ & $\begin{array}{l}\stackrel{0}{m} \\
\stackrel{\oplus}{+}\end{array}$ & $\underset{\infty}{\circ}$ & $\underset{0}{\stackrel{Z}{0}}$ & 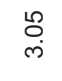 & $\begin{array}{l}\text { ¿ } \\
0\end{array}$ & $\underset{\stackrel{N}{\sim}}{\stackrel{\sim}{\leftarrow}}$ & $\begin{array}{l}\text { to } \\
\text { ¿ }\end{array}$ & $\stackrel{\mathscr{\leftrightarrow}}{\leftarrow}$ & ợ & 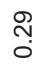 & & $\begin{array}{l}\stackrel{+}{0} \\
\stackrel{0}{\circ}\end{array}$ \\
\hline $\mathbf{z}$ & 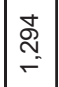 & & $\begin{array}{l}\overline{0} \\
\dot{0}\end{array}$ & 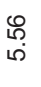 & ' & $\begin{array}{l}\bar{\sigma} \\
\stackrel{\rho}{\sigma}\end{array}$ & $\stackrel{\varrho}{\stackrel{N}{N}}$ & $\begin{array}{l}\text { ల్ } \\
\text { ○. }\end{array}$ & $\stackrel{m}{\leftarrow}$ & ' & 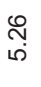 & ' & $\stackrel{\circ}{\circ}$ & $\begin{array}{l}\infty \\
\stackrel{0}{0}\end{array}$ & & ' & $\begin{array}{l}\hat{\omega} \\
0 \\
0\end{array}$ \\
\hline$\frac{0}{\Sigma}$ & $\mid \begin{array}{l}\overline{\tilde{m}} \\
0 \\
\tilde{m}\end{array}$ & & $\begin{array}{l}0 \\
\infty \\
\dot{\sigma}\end{array}$ & 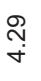 & চ্. & 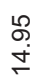 & \& & $\underset{\sigma}{\sigma}$ & $\begin{array}{l}\stackrel{\wp}{O} \\
\stackrel{+}{ }\end{array}$ & ' & $\begin{array}{l}\stackrel{?}{N} \\
\stackrel{6}{6}\end{array}$ & $\stackrel{\text { ஜ̊ }}{0}$ & 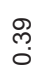 & ¿̛̃ & $\underset{0}{\tau}$ & ' & $\begin{array}{l}\stackrel{+}{0} \\
0\end{array}$ \\
\hline ב & $\mid \begin{array}{l}\mathbb{Z} \\
\mathbb{C} \\
\tilde{N}\end{array}$ & & $\begin{array}{l}7 \\
\stackrel{\rho}{ }\end{array}$ &  & $\underset{\dot{m}}{\bar{m}}$ & $\stackrel{\text { ָे }}{\stackrel{\text { }}{\mathrm{j}}}$ & $\underset{+}{\stackrel{\leftrightarrow}{+}}$ & 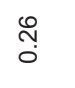 & 号 & $\stackrel{\text { O̊ }}{\circ}$ & $\stackrel{\stackrel{R}{R}}{\stackrel{2}{\sim}}$ & ' & זొ & 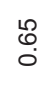 & $\stackrel{\circ}{\circ}$ & ' & $\begin{array}{l}\stackrel{\llcorner}{\circ} \\
\stackrel{\sim}{\sigma}\end{array}$ \\
\hline $\begin{array}{l}\frac{m}{\underline{\alpha}} \\
\frac{\tilde{x}}{z}\end{array}$ & $\underset{\stackrel{\sim}{N}}{=}$ & & 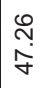 & $\stackrel{g}{+}$ & $\stackrel{0}{\circ}$ & $\begin{array}{l}\stackrel{0}{0} \\
\infty \\
\infty\end{array}$ & 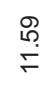 & î & $\stackrel{\infty}{\stackrel{\infty}{-}}$ & ' & $\begin{array}{l}\stackrel{\infty}{\infty} \\
\stackrel{\infty}{\leftarrow}\end{array}$ & ' & $\stackrel{\Gamma}{r}$ & $\stackrel{0}{\circ}$ & ' & ' & 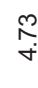 \\
\hline $\begin{array}{l}\sum_{n} \\
\sum_{\underline{z}}\end{array}$ & $\begin{array}{l}\mathfrak{N} \\
\stackrel{S}{\sigma} \\
-\end{array}$ & & $\begin{array}{l}\hat{\theta} \\
\dot{f}\end{array}$ & $\stackrel{\hat{f}}{\dot{\sigma}}$ & $\stackrel{\stackrel{\leftrightarrow}{̣}}{\sim}$ & $\begin{array}{l}\stackrel{2}{\circ} \\
\circ \\
\circ\end{array}$ & $\stackrel{\text { L }}{\stackrel{1}{r}}$ & 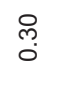 & $\stackrel{m}{\grave{i}}$ & ' & $\begin{array}{l}\stackrel{m}{\circ} \\
\stackrel{\sigma}{\sigma}\end{array}$ & ' & ণָ & $\overline{0}$ & $\stackrel{2}{\circ}$ & ' & $\stackrel{\circ}{\circ}$ \\
\hline $\begin{array}{l}\text { 号 } \\
\text { 之 }\end{array}$ & 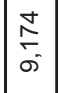 & & $\frac{\hat{m}}{\dot{n}}$ & ळ̊ & 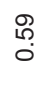 & 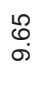 & $\underset{\stackrel{N}{F}}{\stackrel{F}{F}}$ & $\stackrel{\stackrel{8}{\circ}}{\leftarrow}$ & $\stackrel{\sigma}{\leftarrow}$ & $\stackrel{m}{\circ}$ & $\begin{array}{l}\mathscr{m} \\
\stackrel{\leftrightarrow}{+}\end{array}$ & 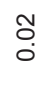 & $\stackrel{\text { లొ }}{0}$ & $\stackrel{\infty}{\stackrel{\infty}{0}}$ & $\stackrel{\circ}{\circ}$ & סִ & 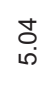 \\
\hline 占 & $\mid \begin{array}{c}\tilde{N} \\
\tilde{N} \\
\tilde{N}\end{array}$ & & $\begin{array}{l}\infty \\
\infty \\
\infty \\
\stackrel{\infty}{N}\end{array}$ & $\begin{array}{l}0 \\
\stackrel{0}{0} \\
6\end{array}$ & $\stackrel{\stackrel{\infty}{̣}}{\sim}$ & $\begin{array}{l}\stackrel{\infty}{N} \\
\stackrel{N}{N}\end{array}$ & $\begin{array}{l}\stackrel{L}{\circ} \\
\stackrel{p}{\sigma}\end{array}$ & ' & 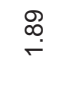 & ' & 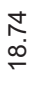 & $\begin{array}{l}8 \\
\text { : } \\
\end{array}$ & 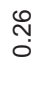 & ठே. & $\begin{array}{l}\Delta \\
0\end{array}$ & ' & $\stackrel{\circ}{\stackrel{\circ}{\wedge}}$ \\
\hline 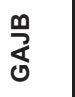 & 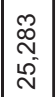 & & $\begin{array}{l}\infty \\
\stackrel{+}{+} \\
\stackrel{\sim}{ }\end{array}$ & $\stackrel{\circ}{r}$ & $\underset{\text { i }}{\text { ì }}$ & $\begin{array}{l}\text { f̊ } \\
\stackrel{\circ}{\leftarrow}\end{array}$ & $\stackrel{\infty}{\stackrel{\infty}{F}}$ & $\begin{array}{l}\infty \\
\stackrel{0}{0}\end{array}$ & 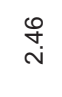 & ' & $\begin{array}{l}\stackrel{8}{\circ} \\
\stackrel{\leftrightarrow}{\circ}\end{array}$ & $\begin{array}{l}\text { ¿ } \\
\text { : }\end{array}$ & $\underset{m}{\check{m}}$ & $\begin{array}{l}\bar{i} \\
0\end{array}$ & $\stackrel{m}{\circ}$ & , & $\begin{array}{l}\circ \\
\stackrel{\circ}{\circ}\end{array}$ \\
\hline D & 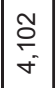 & & $\begin{array}{l}\widetilde{N} \\
\stackrel{\text { లె }}{ }\end{array}$ & $\begin{array}{l}0 \\
\stackrel{0}{0} \\
\stackrel{0}{0}\end{array}$ & $\stackrel{\leftrightarrow}{\stackrel{\leftrightarrow}{\leftrightarrow}}$ & $\begin{array}{l}\stackrel{\infty}{\infty} \\
\stackrel{0}{\circ}\end{array}$ & $\stackrel{\infty}{\sim}$ & $\stackrel{\mathscr{0}}{0}$ & 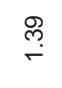 & ' & 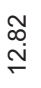 & ' & in & 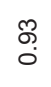 & $\stackrel{\llcorner}{\circ}$ & ָ̊م & $\begin{array}{l}\stackrel{8}{ } \\
\stackrel{0}{\circ} \\
\stackrel{0}{\sim}\end{array}$ \\
\hline 㟧 & 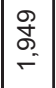 & & 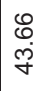 & $\underset{\infty}{\stackrel{\infty}{\infty}}$ & 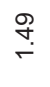 & $\begin{array}{l}\text { 옹 } \\
\stackrel{0}{\circ}\end{array}$ & $\underset{\text { i⿱ }}{\stackrel{R}{2}}$ & $\begin{array}{c}0 \\
\text { m. } \\
0\end{array}$ & $\stackrel{+}{\stackrel{+}{r}}$ & ' & $\begin{array}{l}\tilde{\sigma} \\
\stackrel{+}{+}\end{array}$ & ' & 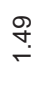 & $\bar{m}$ & $\begin{array}{l}0 \\
\stackrel{0}{0} \\
0\end{array}$ & ' & $\begin{array}{l}\stackrel{\infty}{\infty} \\
\stackrel{0}{0}\end{array}$ \\
\hline \multirow[t]{2}{*}{ 岂 } & 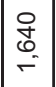 & & $\begin{array}{l}8 \\
\dot{+} \\
\dot{f}\end{array}$ & 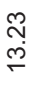 & $\stackrel{\infty}{\sim}$ & $\begin{array}{l}\text { ㅇ. } \\
\text { }\end{array}$ & $\stackrel{N}{\overparen{O}}$ & $\begin{array}{l}\stackrel{R}{0} \\
0\end{array}$ & $\underset{\mathrm{N}}{\mathrm{N}}$ & ' & $\stackrel{\stackrel{\infty}{\sim}}{\Gamma}$ & $\stackrel{8}{\circ}$ & $\stackrel{\leftrightarrow}{\stackrel{\leftrightarrow}{\leftarrow}}$ & $\begin{array}{l}R \\
\stackrel{2}{0}\end{array}$ & $\stackrel{N}{\circ}$ & ' & 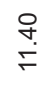 \\
\hline & 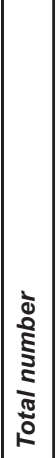 & 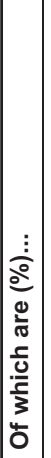 & 岂 & 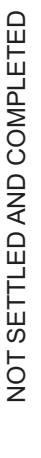 & 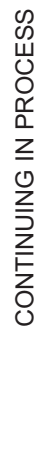 & 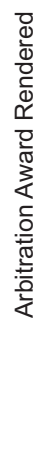 & 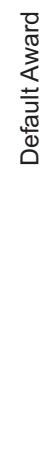 & 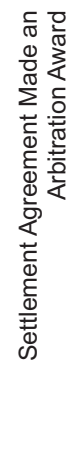 & 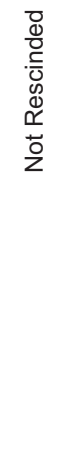 & 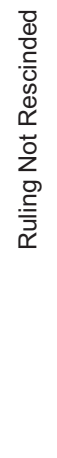 & 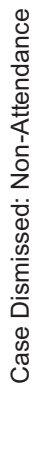 & 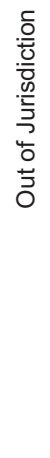 & 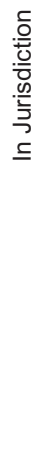 & 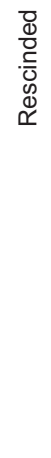 & $\begin{array}{l}\bar{d} \\
\frac{\Phi}{0} \\
0 \\
\overline{0} \\
0\end{array}$ & 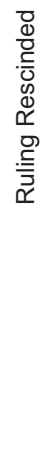 & 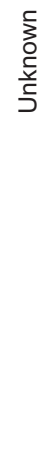 \\
\hline
\end{tabular}


Table A10: Outcome of Dismissal Cases by Main Sectors 2001/02

\begin{tabular}{|c|c|c|c|c|c|c|c|c|c|c|c|c|c|c|}
\hline & $\frac{}{}$ & & 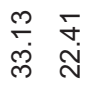 & $\stackrel{\infty}{\stackrel{0}{0}}$ & $\frac{\infty}{\infty}$ & $\stackrel{\nabla}{\check{r}}$ & ' & & $\stackrel{F}{\check{r}}$ & $\stackrel{\varphi}{\dot{\varphi}}$ & $\stackrel{N}{\stackrel{N}{\leftarrow}}$ & $\frac{\pi}{\sigma}$ & & 守 \\
\hline 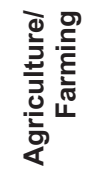 & $\begin{array}{l}\infty \\
\stackrel{\infty}{\circ} \\
\stackrel{-}{-}\end{array}$ & & 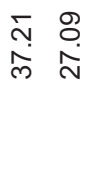 & $\stackrel{\nwarrow ָ}{0}$ & $\begin{array}{l}\stackrel{\forall}{\circ} \\
\dot{\sim}\end{array}$ & $\begin{array}{l}\text { J़ } \\
\stackrel{0}{\circ}\end{array}$ & ' & $\stackrel{\circ}{\circ}$ & $\begin{array}{l}\infty \\
\stackrel{\infty}{+}\end{array}$ & $\begin{array}{c}\underset{\omega}{\omega} \\
\stackrel{N}{ }\end{array}$ & $\stackrel{\infty}{\infty}$ & $\frac{\circ}{\circ}$ & $\stackrel{\text { L }}{\circ}$ & $\begin{array}{l}\bar{\sigma} \\
\infty\end{array}$ \\
\hline 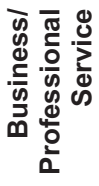 & \begin{tabular}{l}
\multirow{2}{N}{} \\
i
\end{tabular} & & $\stackrel{\infty}{\stackrel{\infty}{\dot{D}}}$ & $\begin{array}{l}\mathfrak{N} \\
0 \\
0\end{array}$ & $\stackrel{\text { ָे }}{\stackrel{\sim}{\sim}}$ & $\begin{array}{l}\stackrel{0}{N} \\
\stackrel{N}{N}\end{array}$ & ' & $\stackrel{\text { ¿ }}{r}$ & J & $\underset{\sim}{\stackrel{\oplus}{m}}$ & $\stackrel{+}{\circ}$ & $\stackrel{\text { N }}{\circ}$ & 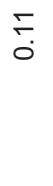 & $\begin{array}{l}\stackrel{0}{1} \\
\stackrel{1}{0}\end{array}$ \\
\hline 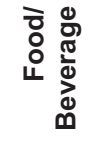 & $\begin{array}{l}2 \\
0 \\
0 \\
i\end{array}$ & & 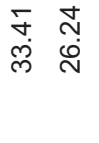 & 苫 & $\stackrel{\nabla}{\grave{i}}$ & $\stackrel{\mathscr{R}}{\stackrel{R}{\leftarrow}}$ & $\begin{array}{l}\text { ¿ } \\
0\end{array}$ & $\stackrel{\text { pे }}{\leftarrow}$ & $\underset{\stackrel{g}{+}}{+}$ & $\begin{array}{l}\stackrel{q}{~} \\
\dot{m}\end{array}$ & $\stackrel{8}{\circ}$ & $\grave{N}$ & $\stackrel{5}{\circ}$ & 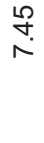 \\
\hline 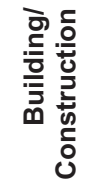 & 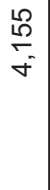 & & $\begin{array}{l}\hat{\alpha} \\
\text { ले } \\
\text { ले }\end{array}$ & in & $\begin{array}{l}\stackrel{\infty}{\infty} \\
\stackrel{\sim}{\sim}\end{array}$ & $\stackrel{m}{m}$ & ' & $\stackrel{\text { }}{\leftarrow}$ & $\stackrel{\varphi}{\dot{\theta}}$ & $\stackrel{?}{\stackrel{i}{N}}$ & $\stackrel{\sim}{\sim}$ & $\stackrel{5}{\circ}$ & $\begin{array}{l}\hat{\circ} \\
\circ\end{array}$ & @̊ \\
\hline 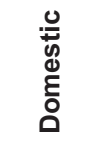 & 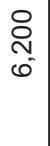 & & $\begin{array}{ll}\bar{N} & \stackrel{Q}{N} \\
\underset{\mathcal{N}}{*} & \mathbb{N}\end{array}$ & $\begin{array}{l}\stackrel{0}{0} \\
\text { ల. }\end{array}$ & 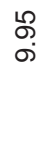 & $\underset{r}{R}$ & ' & $\begin{array}{l}0 \\
\infty \\
0\end{array}$ & $\underset{\hat{\theta}}{\hat{N}}$ & 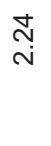 & $\stackrel{m}{\leftarrow}$ & 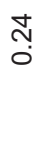 & ' & $\begin{array}{l}\infty \\
\stackrel{0}{0} \\
\dot{\sigma}\end{array}$ \\
\hline 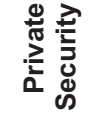 & $\begin{array}{l}\infty \\
0 \\
m \\
0\end{array}$ & & 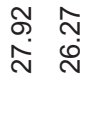 & 占 & $\begin{array}{l}\text { ¿ } \\
\text { ¿ }\end{array}$ & $\begin{array}{l}\stackrel{8}{\infty} \\
\stackrel{N}{ }\end{array}$ & ' & 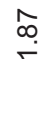 & $\underset{D}{\stackrel{J}{r}}$ & $\begin{array}{l}\stackrel{\circ}{\leftrightarrow} \\
\stackrel{N}{ }\end{array}$ & $\stackrel{5}{-}$ & $\stackrel{\circ}{\circ}$ & $\begin{array}{l}\infty \\
\circ \\
0\end{array}$ & $\frac{\sigma}{\sigma}$ \\
\hline 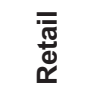 & 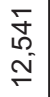 & & $\begin{array}{ll}\stackrel{N}{N} \\
\text { N } \\
\text { N }\end{array}$ & 占 & 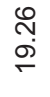 & চே & ' & $\stackrel{\text { Ṇ}}{\leftarrow}$ & $\begin{array}{l}\text { O̦ } \\
\text { in }\end{array}$ & 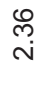 & $\begin{array}{l}\hat{\infty} \\
0 \\
0\end{array}$ & $\frac{10}{0}$ & & ๙ু \\
\hline & 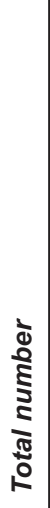 & 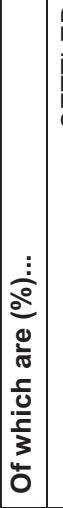 & 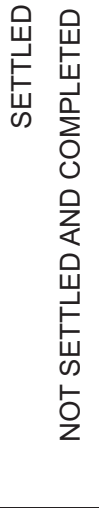 & 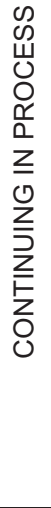 & 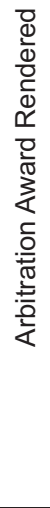 & 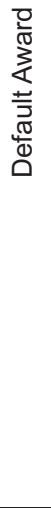 & 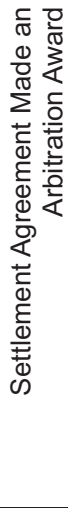 & 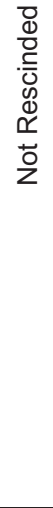 & 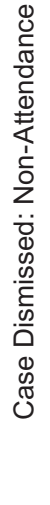 & 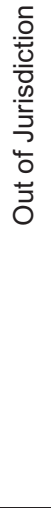 & 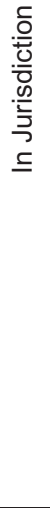 & 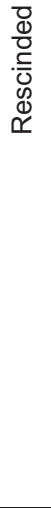 & $\begin{array}{l}\frac{0}{d} \\
\frac{\pi}{0} \\
\overline{0} \\
0 \\
0\end{array}$ & $\begin{array}{l}\frac{5}{3} \\
0 \\
\frac{1}{x} \\
\text { J }\end{array}$ \\
\hline
\end{tabular}


Table A11: Outcome of Dismissal Cases by Main Sectors 2003/04

\begin{tabular}{|c|c|c|c|c|c|c|c|c|c|c|c|c|c|c|c|c|c|}
\hline 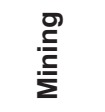 & $\begin{array}{l}\infty \\
0 \\
\infty \\
\infty\end{array}$ & & $\begin{array}{ll}0 & \infty \\
0 & \sim \\
\dot{\varphi} & 0\end{array}$ & $\begin{array}{l}\circ \\
\infty \\
0\end{array}$ & $\begin{array}{l}\text { ¿ } \\
\text { ¿ें }\end{array}$ & $\stackrel{+}{i}$ & & ' & ले & & $\begin{array}{l}\text { : } \\
\text { ¿ें }\end{array}$ & $\stackrel{\circ}{\circ}$ & б. & $\stackrel{\circ}{\circ}$ & $\begin{array}{l}\infty \\
1 \\
0 \\
0 \\
0\end{array}$ & & $\stackrel{\stackrel{D}{N}}{N}$ \\
\hline 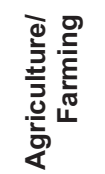 & 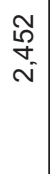 & & \begin{tabular}{ll}
$N$ & 0 \\
$N$ & 0 \\
$\stackrel{\infty}{\infty}$ & 0 \\
\hdashline
\end{tabular} & ח̊ & $\begin{array}{l}\stackrel{\sim}{*} \\
\stackrel{丶}{\sigma}\end{array}$ & $\stackrel{\infty}{\stackrel{\infty}{\sim}}$ & ণ্ণ & & $\stackrel{\infty}{\stackrel{\infty}{N}}$ & $\begin{array}{l}\text { I } \\
\text { : }\end{array}$ & $\begin{array}{l}\dot{5} \\
\stackrel{5}{\Gamma}\end{array}$ & ' & مִ & $\begin{array}{c}\hat{m} \\
0\end{array}$ & $\stackrel{m}{m}$ & & 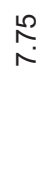 \\
\hline 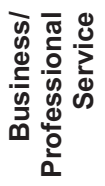 & $\begin{array}{l}\infty \\
\stackrel{\infty}{\infty} \\
\stackrel{+}{\sigma}\end{array}$ & & 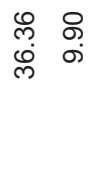 & $\begin{array}{l}\text { मे } \\
\dot{0}\end{array}$ & $\stackrel{\sim}{\leftarrow}$ & $\begin{array}{l}L_{0}^{\circ} \\
1{ }^{\circ}\end{array}$ & 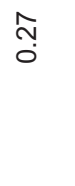 & ' & $\begin{array}{l}\mathscr{C} \\
\ddot{m}\end{array}$ & ' & $\stackrel{\oplus}{\oplus}$ & 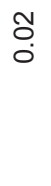 & $\stackrel{m}{\circ}$ & 守 & $\stackrel{m}{\circ}$ & 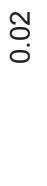 & $\begin{array}{l}\text { in } \\
\text { के }\end{array}$ \\
\hline 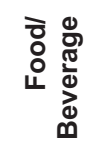 & $\begin{array}{l}\infty \\
\infty \\
\infty \\
m\end{array}$ & & 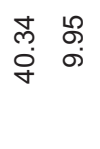 & $\stackrel{8}{\circ}$ & $\begin{array}{l}-\infty \\
0 \\
0\end{array}$ & $\stackrel{\infty}{\stackrel{\infty}{\sim}}$ & $\stackrel{m}{\circ}$ & ' & $\stackrel{\text { ֻ }}{\mathrm{N}}$ & $\stackrel{8}{\circ}$ & $\begin{array}{l}\stackrel{M}{\sim} \\
\stackrel{+}{\tau}\end{array}$ & ஜ̊ & $\underset{\leftarrow}{\check{r}}$ & $\underset{m}{\bar{o}}$ & $\begin{array}{l}\text { J } \\
0\end{array}$ & ' & $\underset{\sim}{\stackrel{O}{r}}$ \\
\hline 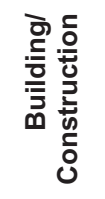 & $\begin{array}{l}\stackrel{m}{\sim} \\
\underset{\nabla}{+}\end{array}$ & &  & $\begin{array}{l}\hat{0} \\
0\end{array}$ & 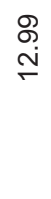 & 倠 & $\stackrel{\text { లె }}{0}$ & ' & $\underset{\dot{m}}{\bar{m}}$ & ' & $\begin{array}{l}\hat{o} \\
\stackrel{\sigma}{\sigma}\end{array}$ & $\stackrel{m}{\circ}$ & $\stackrel{\infty}{\circ}$ & ז̊ & $\begin{array}{l}\infty \\
\stackrel{\infty}{0}\end{array}$ & ' & م \\
\hline  & $\begin{array}{l}\tilde{R} \\
\stackrel{0}{0} \\
\stackrel{-}{\circ}\end{array}$ & & 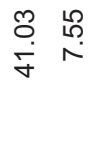 & ๗ָ' & $\begin{array}{l}\stackrel{8}{ } \\
\infty\end{array}$ & 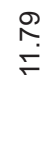 & $\stackrel{\circ}{\circ}$ & ' & $\stackrel{m}{\dot{m}}$ & $\check{o}_{0}$ & $\begin{array}{l}5 \\
\infty \\
\infty \\
\leftarrow\end{array}$ & 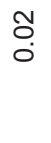 & $\stackrel{⿱ 亠 䒑}{\leftarrow}$ & $\hat{m}$ & ' & ' & 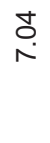 \\
\hline 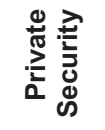 & $\begin{array}{l}\bar{\delta} \\
\substack{0 \\
N}\end{array}$ & & 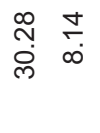 & $\hat{N}$ & $\begin{array}{l}\text { N } \\
\text { Oे }\end{array}$ & $\begin{array}{l}\text { षे } \\
\dot{0}\end{array}$ & 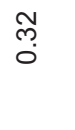 & סo & $\stackrel{n}{\forall}$ & ' & $\begin{array}{l}\text { : } \\
\text { iे }\end{array}$ & 广্ & চ் & مُ & $\stackrel{ }{\circ}$ & ' & $\begin{array}{l}\hat{1} \\
0\end{array}$ \\
\hline 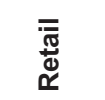 & 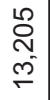 & & $\begin{array}{cc}\infty & \bar{f} \\
\stackrel{+}{\tau} & \infty\end{array}$ & סo & $\stackrel{m}{\stackrel{m}{\leftarrow}}$ & $\begin{array}{l}\mathbb{B} \\
6 \\
\dot{0}\end{array}$ & $\stackrel{\text { N̦}}{0}$ & & 户্লি. & $\begin{array}{l}\text { Oे } \\
\text { Oे }\end{array}$ & $\begin{array}{l}\stackrel{\varrho}{\sim} \\
\stackrel{+}{\leftarrow}\end{array}$ & ợ & $\stackrel{N}{\circ}$ & $\begin{array}{l}\text { N̦ } \\
\text { O }\end{array}$ & $\stackrel{\circ}{\frac{0}{0}}$ & ' & $\begin{array}{l}0 \\
\stackrel{0}{0}\end{array}$ \\
\hline & 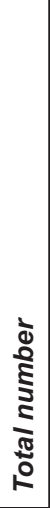 & 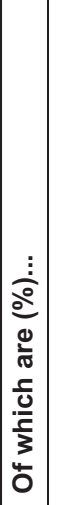 & 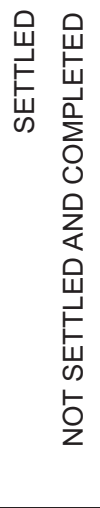 & 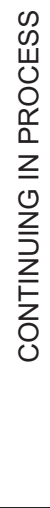 & 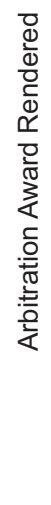 & 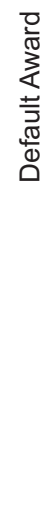 & 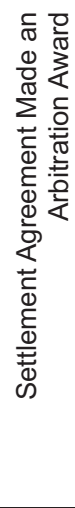 & 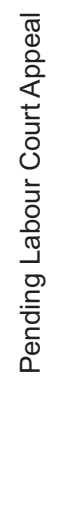 & 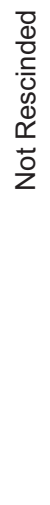 & 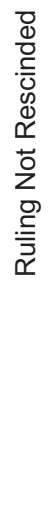 & 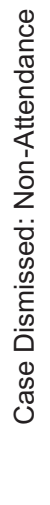 & 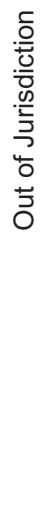 & 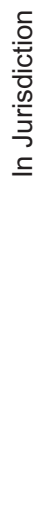 & 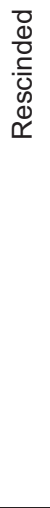 & $\frac{\bar{d}}{\frac{d}{0}}$ & 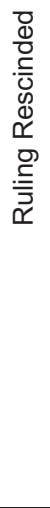 & $\begin{array}{l}\frac{5}{3} \\
0 \\
\frac{5}{5} \\
5\end{array}$ \\
\hline
\end{tabular}


Table A12: Outcome of Dismissal Cases by Main Sectors 2004/05

\begin{tabular}{|c|c|c|c|c|c|c|c|c|c|c|c|c|c|c|c|c|c|}
\hline 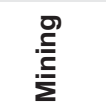 & $\begin{array}{l}m \\
\check{\sigma} \\
m\end{array}$ & & 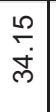 & $\stackrel{\Xi}{\dagger}$ & $\begin{array}{l}0 \\
\stackrel{\omega}{N}\end{array}$ & 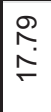 & $\begin{array}{l}\infty \\
\stackrel{\infty}{n} \\
\dot{m}\end{array}$ & ণ্ণ & $\begin{array}{l}\stackrel{N}{N} \\
\text { N }\end{array}$ & \begin{tabular}{|l|} 
\\
0 \\
0
\end{tabular} & 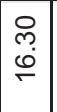 & \begin{tabular}{|l|} 
\\
0 \\
0 \\
0
\end{tabular} & 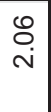 & \begin{tabular}{|l|} 
\\
$\stackrel{m}{*}$ \\
\end{tabular} & స̃ & 1 & $\begin{array}{l}\stackrel{\leftrightarrow}{\sim} \\
\stackrel{\sim}{\sim}\end{array}$ \\
\hline  & $\begin{array}{l}\stackrel{8}{0} \\
\ddot{\circ} \\
\text { ले }\end{array}$ & & $\begin{array}{l}\text { g } \\
\dot{0} \\
\dot{m}\end{array}$ & $\begin{array}{l}\delta \\
\infty \\
\infty\end{array}$ & $\stackrel{R}{\stackrel{R}{\leftarrow}}$ & $\stackrel{\infty}{\stackrel{\infty}{\leftarrow}}$ & $\begin{array}{l}\mathscr{8} \\
0 \\
+\end{array}$ & ণ্ণে & $\stackrel{\bar{m}}{\sim}$ & $\begin{array}{l}0 \\
0 \\
0\end{array}$ & 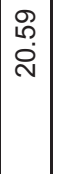 & $\begin{array}{l}1 \\
0 \\
0\end{array}$ & 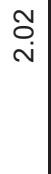 & 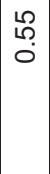 & 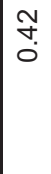 & ' & 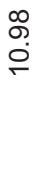 \\
\hline 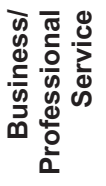 & $\begin{array}{l}\text { స్ } \\
\text { م్ } \\
\text { దే }\end{array}$ & & 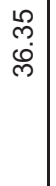 & 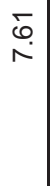 & $\stackrel{\mathfrak{N}}{\stackrel{一}{\leftarrow}}$ & \begin{tabular}{|l}
$\infty$ \\
\multirow{2}{*}{} \\
$\stackrel{\infty}{\circ}$
\end{tabular} & 草 & 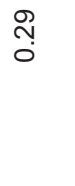 & $\stackrel{\dddot{m}}{N}$ & $\mid \begin{array}{l}\tilde{O} \\
0 \\
\dot{0}\end{array}$ & 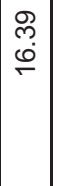 & \begin{tabular}{c}
$\tilde{O}$ \\
\hdashline \\
\hdashline
\end{tabular} & $\underset{\sim}{\stackrel{\sim}{N}}$ & $\begin{array}{l}\mathscr{\Theta} \\
\stackrel{\leftrightarrow}{0}\end{array}$ & $\frac{N}{o}$ & ' & $\begin{array}{l}\stackrel{\circ}{\text { m. }} \\
\stackrel{\circ}{\circ}\end{array}$ \\
\hline 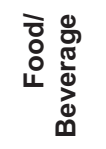 &  & & $\overline{\dot{p}}$ & \begin{tabular}{|l|} 
\\
\end{tabular} & $\stackrel{\text { م }}{-}$ & 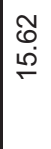 & 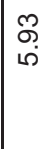 & 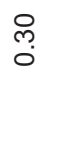 & $\begin{array}{l}\stackrel{n}{n} \\
\text { Ni }\end{array}$ & ' & 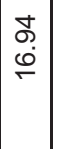 & \begin{tabular}{|l|} 
\\
0 \\
0 \\
\end{tabular} & $\underset{\forall}{\stackrel{f}{*}}$ & \begin{tabular}{|l|} 
\\
\\
0 \\
\end{tabular} & $\begin{array}{l}\text { o } \\
\text { o } \\
0\end{array}$ & ח̊ & $\frac{}{\infty}$ \\
\hline  & $\begin{array}{l}0 \\
\text { ட. } \\
O \\
i n\end{array}$ & & $\begin{array}{l}\text { ৪ } \\
\text { ஸें }\end{array}$ & $\frac{1}{\dot{0}}$ & $\stackrel{\leftrightarrow}{\odot}$ &  & 容 & $\stackrel{\widetilde{m}}{\circ}$ & $\begin{array}{l}\mathscr{8} \\
\text { ì }\end{array}$ & ' & $\begin{array}{l}\frac{0}{\sigma} \\
\frac{\sigma}{\sigma}\end{array}$ & $\begin{array}{l}\dot{0} \\
0 \\
0\end{array}$ & $\underset{\sim}{\stackrel{N}{N}}$ & $\begin{array}{l}0 \\
\stackrel{1}{0} \\
0 \\
0\end{array}$ & $\begin{array}{l}\text { Oे } \\
0\end{array}$ & ' & $\stackrel{\mathscr{C}}{0}$ \\
\hline 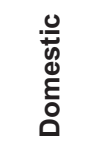 & $\begin{array}{l}\frac{8}{0} \\
\sigma\end{array}$ & &  & \begin{tabular}{|l|}
\multirow{2}{*}{} \\
$\stackrel{+}{+}$ \\
\end{tabular} & \begin{tabular}{|l|} 
\\
$\infty$ \\
0 \\
0
\end{tabular} & $\stackrel{\infty}{\circ}$ & $\begin{array}{l}\underset{N}{N} \\
\stackrel{N}{2}\end{array}$ & $\stackrel{\infty}{\circ}$ & $\begin{array}{l}\infty \\
\stackrel{0}{ } \\
\text { Ni }\end{array}$ & \begin{tabular}{l|} 
\\
0 \\
0
\end{tabular} & $\begin{array}{l}\stackrel{N}{\check{2}} \\
\stackrel{5}{\sim}\end{array}$ & \begin{tabular}{|l|} 
\\
$O$ \\
0 \\
0
\end{tabular} & 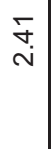 & $\begin{array}{l}8 \\
\\
0\end{array}$ & ' & 1 & ๙్ \\
\hline 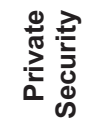 & $\begin{array}{c}\stackrel{m}{\circ} \\
\stackrel{\infty}{\infty}\end{array}$ & & $\begin{array}{l}\text { N } \\
\infty \\
\sim\end{array}$ & 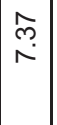 & $\stackrel{\stackrel{\rho}{p}}{\sim}$ & $\begin{array}{l}\text { o } \\
\text { ते }\end{array}$ & $\begin{array}{l}m \\
\tilde{m} \\
\sigma\end{array}$ & $\begin{array}{l}0 \\
\text { مִ } \\
0\end{array}$ & $\stackrel{\stackrel{R}{R}}{\stackrel{N}{N}}$ & \begin{tabular}{|l|}
2 \\
0 \\
0
\end{tabular} \mid & $\begin{array}{l}\tilde{m} \\
\stackrel{\sigma}{\sigma}\end{array}$ & 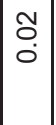 & $\stackrel{+}{\infty}$ & $\begin{array}{l}0 \\
\stackrel{1}{6} \\
0 \\
0\end{array}$ & $\begin{array}{l}\text { Oे } \\
0\end{array}$ & ' & $\frac{\sigma}{\infty}$ \\
\hline \multirow{2}{*}{ 矛 } & 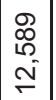 & & $\begin{array}{l}\text { ৪ } \\
\stackrel{\text { m}}{ }\end{array}$ & 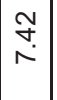 & 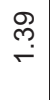 & $\begin{array}{l}\stackrel{\circledast}{N} \\
\stackrel{6}{0}\end{array}$ & 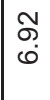 & 웜 & ले & $\begin{array}{l}m \\
0 \\
0\end{array}$ & 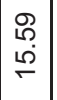 & $\begin{array}{l} \\
0 \\
0\end{array}$ & 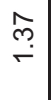 & 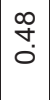 & $\begin{array}{l}0 \\
0 \\
0\end{array}$ & ' & $\begin{array}{l}\stackrel{m}{\sim} \\
\infty\end{array}$ \\
\hline & 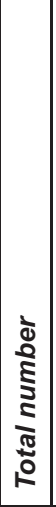 & 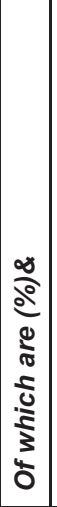 & $\begin{array}{l}\text { 岂 } \\
\stackrel{F}{\underline{w}} \\
\text { 心 }\end{array}$ & 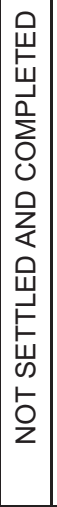 & 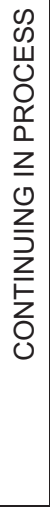 &  & 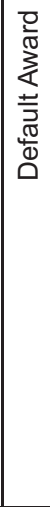 & 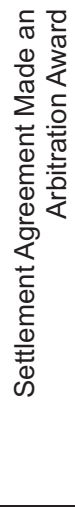 & 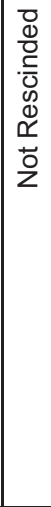 & 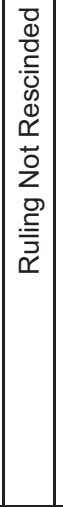 & 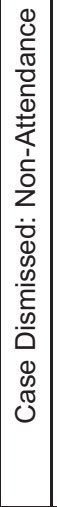 &  & 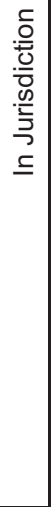 & 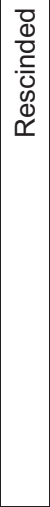 & $\begin{array}{l}0 \\
0 \\
0 \\
0 \\
0 \\
\varepsilon \\
0 \\
0\end{array}$ & 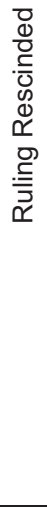 & $\begin{array}{l}\frac{5}{3} \\
\frac{5}{5} \\
\frac{5}{5}\end{array}$ \\
\hline
\end{tabular}

